A NUMERICAL STUDY ON RESPONSE FACTORS FOR STEEL WALL-FRAME SYSTEMS

A THESIS SUBMITTED TO

THE GRADUATE SCHOOL OF NATURAL AND APPLIED SCIENCES OF MIDDLE EAST TECHNICAL UNIVERSITY

BY

HAKAN ARSLAN

IN PARTIAL FULFILLMENT OF THE REQUIREMENTS

FOR

THE DEGREE OF MASTER OF SCIENCE

IN

CIVIL ENGINEERING

AUGUST 2009 
Approval of the thesis:

\section{A NUMERICAL STUDY ON RESPONSE FACTORS FOR STEEL WALL-FRAME SYSTEMS}

submitted by HAKAN ARSLAN in partial fulfillment of the requirements for the degree of Master of Science in Civil Engineering Department, Middle East Technical University by,

Prof. Dr. Canan Özgen

Dean, Graduate School of Natural and Applied Sciences

Prof. Dr. Güney Özcebe

Head of Department, Civil Engineering

Assoc. Prof. Dr. Cem Topkaya

Supervisor, Civil Engineering Dept., METU

\section{Examining Committee Members:}

Assoc. Prof. Dr. Ahmet Yakut

Civil Engineering Dept., METU

Assoc. Prof. Dr. Cem Topkaya

Civil Engineering Dept., METU

Asst. Prof. Dr. Eray Baran

Civil Engineering Dept., Atılım University

Asst. Prof. Dr. Burcu Burak

Civil Engineering Dept., METU

Asst. Prof. Dr. Afşin Sarıtaş

Civil Engineering Dept., METU

Date: 10.08.2009 
I hereby declare that all information in this document has been obtained and presented in accordance with academic rules and ethical conduct. I also declare that, as required by these rules and conduct, I have fully cited and referenced all material and results that are not original to this work.

Name, Last name: Hakan ARSLAN

Signature 


\begin{abstract}
A NUMERICAL STUDY ON RESPONSE FACTORS FOR STEEL WALL-FRAME SYSTEMS

\author{
Arslan, Hakan \\ M.Sc., Department of Civil Engineering \\ Supervisor: Assoc. Prof. Dr. Cem Topkaya
}

August 2009, 78 pages

\begin{abstract}
A numerical study has been undertaken to evaluate the response of dual systems which consist of steel plate shear walls and moment resisting frames. The primary objective of the study was to investigate the influence of elastic base shear distribution between the wall and the frame on the global system response. A total of 10 walls and 30 wall-frame systems, ranging from 3 to 15 stories, were selected for numerical assessment. These systems represent cases in which the elastic base shear resisted by the frame has a share of $10 \%, 25 \%$, or $50 \%$ of the total base shear resisted by the dual system. The numerical study consisted of 1600 time history analyses employing three-dimensional finite elements. All 40 structures were separately analyzed for elastic and inelastic response by subjecting to the selected suite of earthquake records. Interstory drifts, top story drift, base shears resisted by the wall and the frame were collected during each analysis. Based on the analysis results, important response quantities such as the response modification, the overstrength, the displacement amplification and ductility reduction factors are evaluated herein. Results are presented in terms of several measures such as the interstory drift ratio
\end{abstract}


and the top story drift ratio. A discussion related to the influence of load share on the response factors is given.

Key Words: wall-frame; finite element; time history; nonlinear analysis; steel 


\title{
ÖZ
}

\section{ÇELIKK ÇERÇEVE-PERDE KARMA SİSTEMLERINIIN DAVRANIŞ KATSAYILARI ÜZERINE BİR NÜMERIKK ÇALIŞMA}

\author{
Arslan, Hakan \\ Yüksek Lisans, İnşaat Mühendisliği Bölümü \\ Tez Yöneticisi: Doç. Dr. Cem Topkaya
}

Ağustos 2009, 78 sayfa

Moment aktaran çerçeve ile çelik perdelerden oluşan karma sistemlerin davranış katsayılarının değerlendirilmesi için numerik bir çalışma yapılmıştır. Temel amaç duvar ve çerçeve arasında elastik taban kesme kuvveti dağılımının global sistem davranışı üzerine etkilerinin araştırılmasıdır. Toplam 3 ve 15 kat arasında değișen katlara sahip,10 duvar ve 30 karma sistem üzerinde nümerik çalışma yürütülmüştür. $\mathrm{Bu}$ sistemler moment taşıyan çerçeve elastik taban kesme kuvvetinin 10\%, 25\%, ya da 50\% sini taşıyacak şekilde tasarlandı. Söz konusu numerik çalışmada toplam 1600 üç boyutlu sonlu elemanlardan oluşan modeller kullanılarak zaman tanım alanında hesap yapılmıştır. Kırk yapının tamamı için seçilmiş deprem kayıtları altında elastik ve elastik olmayan analizler tamamlanmıştır. Analizler sonucunda yapılarda meydana gelen göreli kat ötelemeleri, tepe katı yerdeğiştirmeleri, duvar ve çerçeve tarafından taşınan taban kesme kuvvetleri kaydedilmiştir. Bu sonuçlar kullanılarak davranış katsayıları - taşıyıcı sistem davranış katsayısı, dayanım azaltma katsayısı, dayanım fazlalığı katsayısı, deplasman büyütme faktörleri - hesaplanmıştır. Sonuçlar göreli kat öteleme oranı ve tepe katı yerdeğiştirme oranı ile ifade edilmiştir. Ayrıca 
elastik yük dağılımının davranış katsayıları üzerine etkileriyle ilgili yorumlara yer verilmiştir.

Anahtar Kelimeler: duvar-çerçeve; sonlu eleman; zaman tanım alanında hesap; doğrusal olmayan analiz; çelik 
To My Family

viii 


\section{ACKNOWLEDGMENTS}

I am grateful to Dr. Cem Topkaya for his supervision, guidance, and patience.

The financial support by the Scientific and Technological Research Council of Turkey (TÜBİTAK) is gratefully acknowledged.

Finally, I would like to thank to my family for their moral support. 


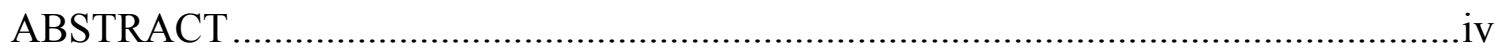

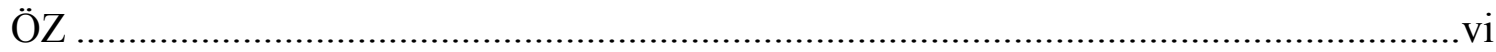

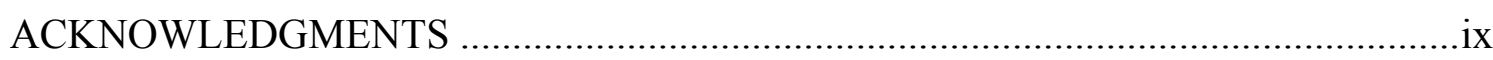

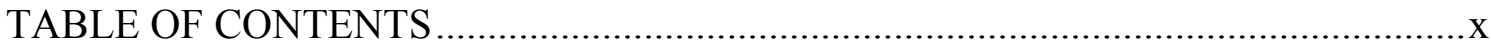

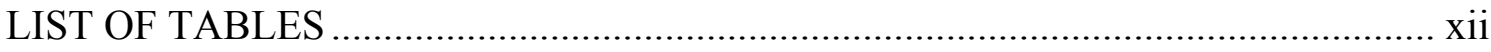

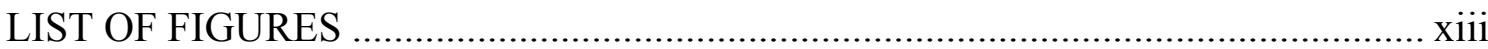

\section{CHAPTERS}

1. INTRODUCTION AND BACKGROUND.......................................................... 1

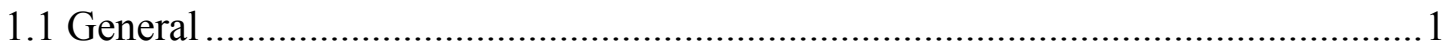

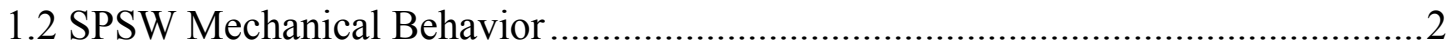

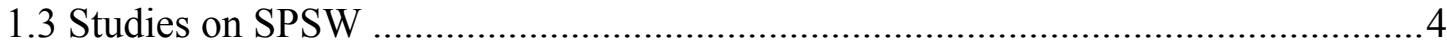

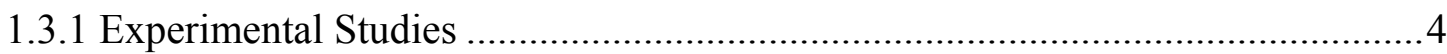

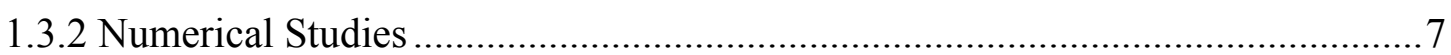

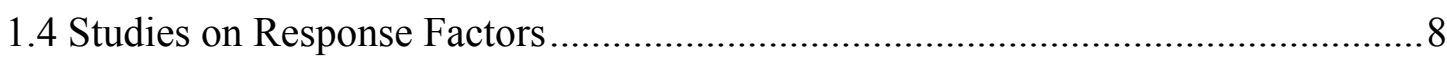

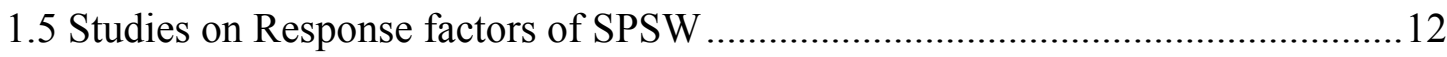

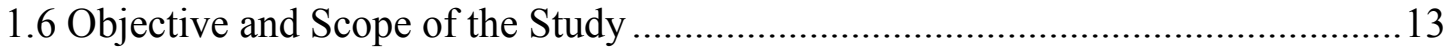

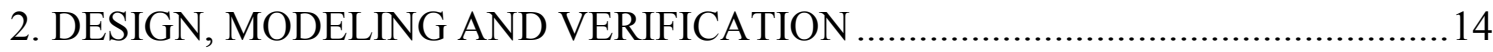

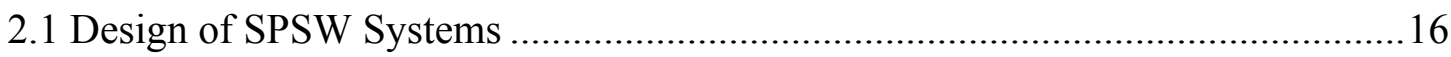

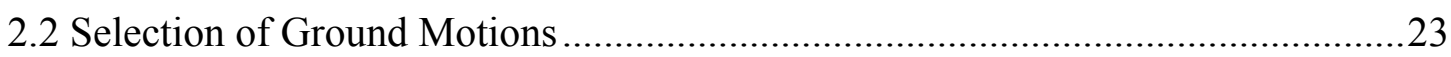

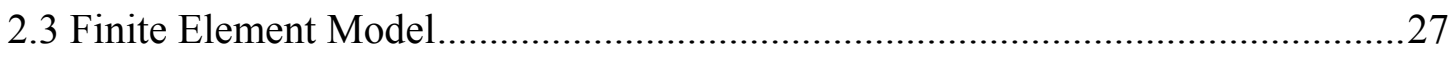

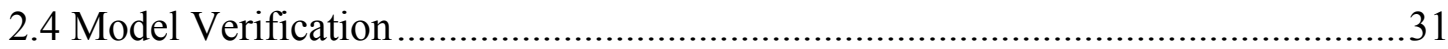




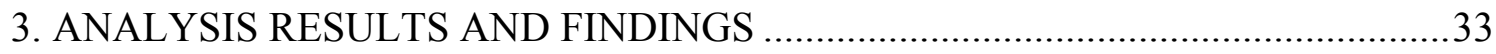

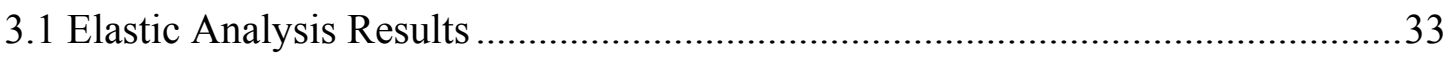

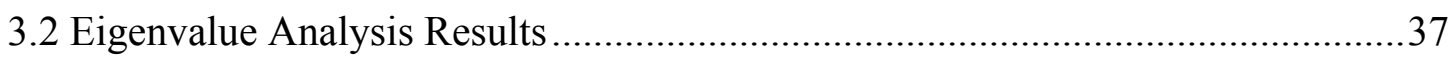

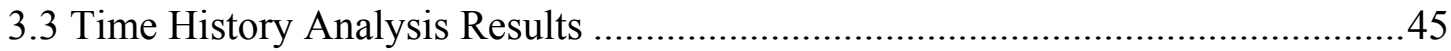

3.4 Overstrength Factor and Estimation of Base Shear at the Collapse Level ............50

3.5 Relationship between Elastic and Inelastic Displacements ................................57

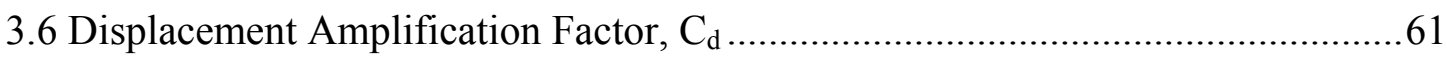

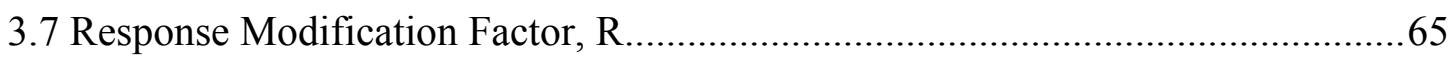

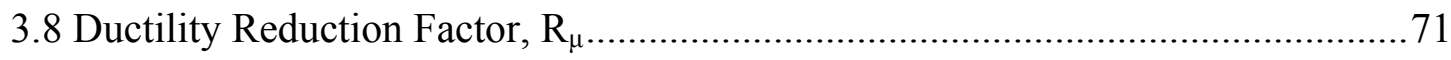

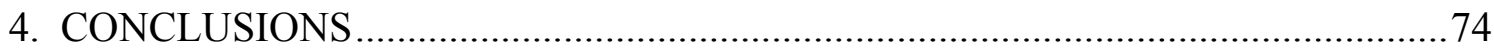

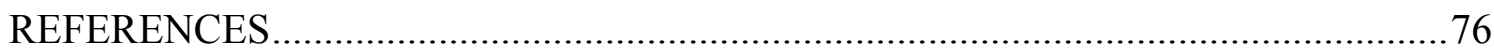




\section{LIST OF TABLES}

\section{TABLES}

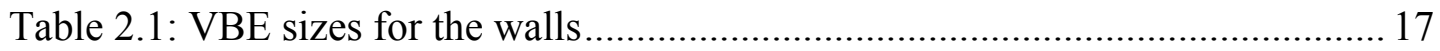

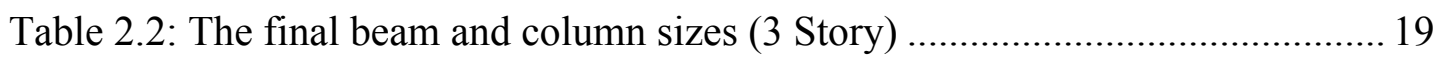

Table 2.3: The final beam and column sizes (6 Story) ............................................. 19

Table 2.4: The final beam and column sizes (9 Story) ............................................. 19

Table 2.5: The final beam and column sizes (12 Story) ......................................... 20

Table 2.6: The final beam and column sizes (15 Story) ......................................... 20

Table 2.7: Details of selected ground motions............................................................ 24

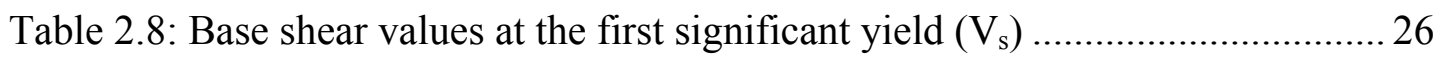

Table 3.1: Vibration mode properties ( $100 \%$ - $0 \%$ cases-300 ton) ............................ 37

Table 3.2: Vibration mode properties (90\% - 10\% cases-300 ton)........................... 38

Table 3.3: Vibration mode properties $(75 \%$ - 25\% cases-300 ton) ............................. 39

Table 3.4: Vibration mode properties (50\% - 50\% cases-300 ton) ............................ 40

Table 3.5: Vibration mode properties (100\% - 0\% cases- 150 ton) ........................... 41

Table 3.6: Vibration mode properties (90\% - 10\% cases- 150 ton) .......................... 42

Table 3.7: Vibration mode properties ( $75 \%$ - 25\% cases- 150 ton) .......................... 43

Table 3.8: Vibration mode properties (50\% - 50\% cases- 150 ton) .......................... 44

Table 3.9: ISDR $_{\mathrm{s}}, \mathrm{ISDR}_{\mathrm{y}}, \mathrm{TSDR}_{\mathrm{s}}$, and $\mathrm{TSDR}_{\mathrm{y}}(100 \%$ - $0 \%$ cases $) \ldots \ldots \ldots \ldots \ldots \ldots \ldots \ldots . . . . . . . . . . . . . .47$

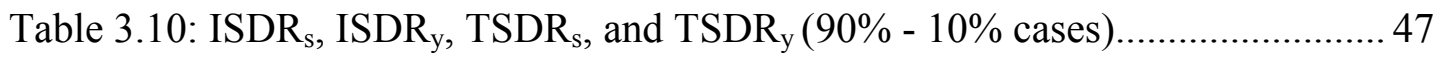

Table 3.11: ISDR $_{\mathrm{s}}, \mathrm{ISDR}_{\mathrm{y}}, \mathrm{TSDR}_{\mathrm{s}}$, and TSDR $(75 \%$ - 25\% cases) ....................... 47

Table 3.12: $\mathrm{ISDR}_{\mathrm{s}}, \mathrm{ISDR}_{\mathrm{y}}, \mathrm{TSDR}_{\mathrm{s}}$, and $\mathrm{TSDR}_{\mathrm{y}}(50 \%-50 \%$ cases $) \ldots \ldots \ldots \ldots \ldots \ldots \ldots \ldots . . . . . . . . . . . .48$ 


\section{LIST OF FIGURES}

\section{FIGURES}

Figure 1.1: Typical Unstiffened Steel Plate Shear Wall ........................................... 3

Figure 1.2: Stresses Imposed on Boundary Elements (Sabelli \& Bruneau, 2007) ...... 3

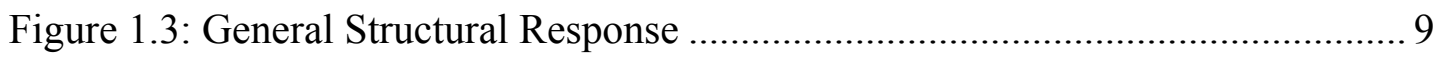

Figure 2.1: Floor Plan for 150 ton Mass per Story .................................................. 15

Figure 2.2: Floor Plan for 300 ton Mass per Story …................................................ 15

Figure 2.3: The Steps Followed in the Study (Compact Version) ............................. 21

Figure 2.4: The Steps Followed in the Study (Detailed Version) .............................. 23

Figure 2.5: Response Spectra for Selected Earthquake Records and Design Base

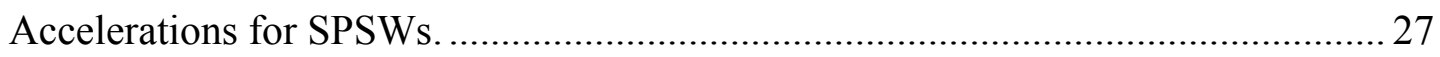

Figure 2.6: A Typical Finite Element Mesh of Wall Frame System ....................... 30

Figure 2.7: A Typical Finite Element Mesh of Wall Only System........................... 31

Figure 2.8: Shear Force-Displacement Response - Experimental .......................... 32

Figure 2.9: Shear Force-Displacement Response - Numerical ............................... 32

Figure 3.1: Story Shear Ratios Resisted by the Wall and the Frame (3 Story)......... 34

Figure 3.2: Story Shear Ratios Resisted by the Wall and the Frame (6 Story)......... 35

Figure 3.3: Story Shear Ratios Resisted by the Wall and the Frame (9 Story)......... 35

Figure 3.4: Story Shear Ratios Resisted by the Wall and the Frame (12 Story)....... 36

Figure 3.5: Story Shear Ratios Resisted by the Wall and the Frame (15 Story)....... 36

Figure 3.6: Pushover-Like Curves for 9 Story Systems - 25\% and 0\% Frame Share 46

Figure 3.7: Pushover-Like Curves for the Wall-Frame, Wall and Frame................. 46

Figure 3.8: A plot for Von Mises Plastic Strain....................................................... 46

Figure 3.9: The Distribution Factors for the Wall.................................................. 53

Figure 3.10: The Distribution Factors for the Frame ............................................. 54

Figure 3.11: The Distribution Factors for the Wall-Frames ................................... 54

Figure 3.12: Frame Contribution in the Inelastic Response ................................... 55

Figure 3.13: Overstrength Possessed by the Systems ............................................. 56

Figure 3.14: ISDR Inelastic / ISDR Elastic for All Data ........................................58 
Figure 3.15: TSDR Inelastic / TSDR Elastic for All Data........................................58

Figure 3.16: ISDR Inelastic / ISDR Elastic for \%0 Frame Contribution................... 59

Figure 3.17: ISDR Inelastic / ISDR Elastic for \%10 Frame Contribution................. 59

Figure 3.18: ISDR Inelastic / ISDR Elastic for \%25 Frame Contribution..................60

Figure 3.19: ISDR Inelastic / ISDR Elastic for \%50 Frame Contribution................. 60

Figure 3.20: R vs. Elastic ISDR / ISDR at First Yield.............................................63

Figure 3.21: R vs. Elastic TSDR / TSDR at First Yield ..........................................63

Figure 3.22: R vs. Cd (Inelastic ISDR / ISDR at First Yield)...................................6 64

Figure 3.23: R vs. Cd (Inelastic TSDR / TSDR at First Yield) ................................. 64

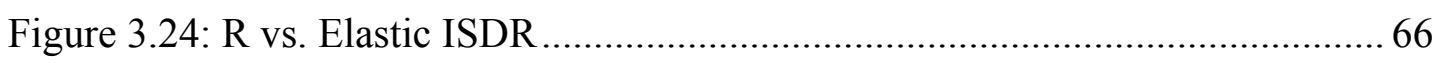

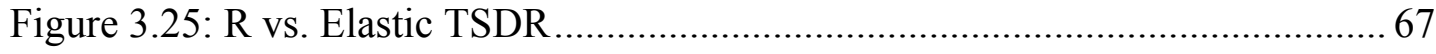

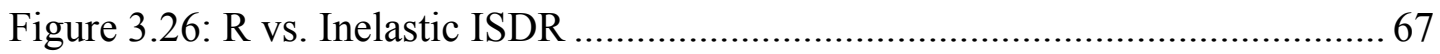

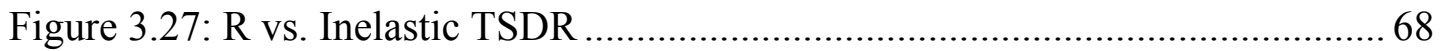

Figure 3.28: R vs. Inelastic ISDR for 0\% Frame Contribution..................................6 68

Figure 3.29: R vs. Inelastic ISDR for 10\% Frame Contribution...............................6 69

Figure 3.30: R vs. Inelastic ISDR for 25\% Frame Contribution...............................6 69

Figure 3.31: R vs. Inelastic ISDR for 50\% Frame Contribution.............................. 70

Figure 3.32: Normalized Response Modification Factor vs. Ratio of Frame Shear to

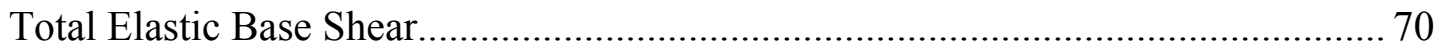

Figure 3.33: Ductility Reduction Factor vs. Inelastic ISDR ................................... 72

Figure 3.34: Ductility Reduction Factor vs. Inelastic TSDR .................................. 72

Figure 3.35: Response Modification Factor vs. Ductility Reduction Factor ............. 73 


\section{CHAPTER 1}

\section{INTRODUCTION AND BACKGROUND}

\subsection{General}

Steel plate shear wall (SPSW) systems have several advantages which make them a very beneficial lateral load resisting system alternative when compared to other steel and concrete lateral load resisting systems (Driver et al., 1998)

Most important advantages of SPSW systems are:

- High initial stiffness

- Superior ductility

- Robust resistance to degradation

- Inherent redundancy

- Increase in plan area

- Reduced foundation loads

- Rapid erection time

There are three types of SPSW systems that can be used in buildings. These are:

- Unstiffened steel plate shear wall systems (SPSW)

- Stiffened steel plate shear wall systems (S-SPSW)

- Composite steel plate shear wall systems (C-SPSW) 
Stiffened and composite steel plate shear wall systems are outside of the scope of this study.

\subsection{SPSW Mechanical Behavior}

SPSW systems consist of slender web plates and surrounding boundary elements (VBE: Vertical Boundary Element and HBE: Horizontal Boundary Element) as shown in Figure 1.1. Slender webs of SPSW systems are not capable of carrying high compressive loads and they buckle under the action of principal compressive stresses. At this point, lateral loads are transferred in the system by the development of principal tension stresses. In other words, post-buckling strength of SPSW systems is due to tension field action mechanism. Stresses developed in the post buckling stage are shown in Figure 1.2. After post buckling, since the plate yields, surrounding boundary elements contribute to lateral load resistance with frame action. 


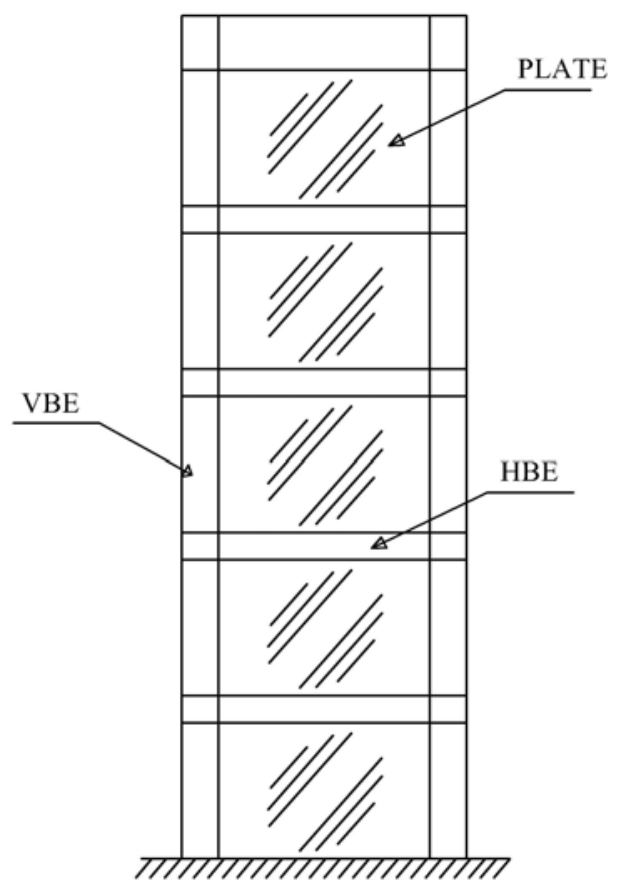

Figure 1.1: Typical Unstiffened Steel Plate Shear Wall

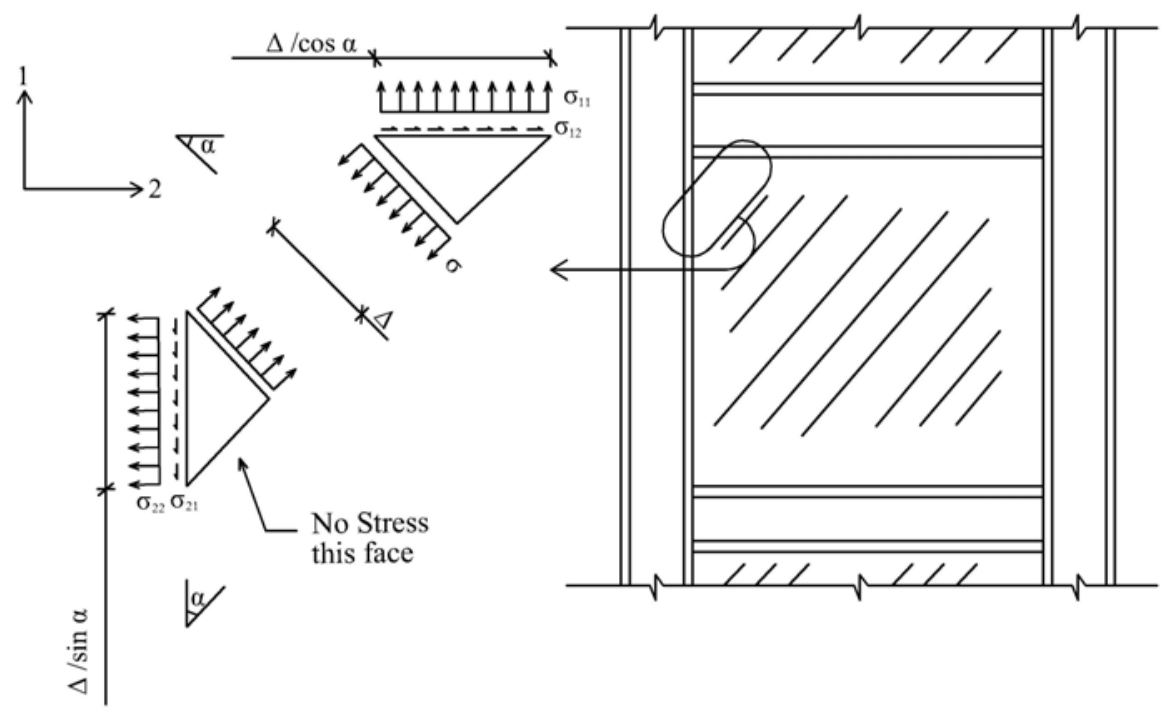

Figure 1.2: Stresses Imposed on Boundary Elements (Sabelli \& Bruneau, 2007) 


\subsection{Studies on SPSW}

Seismic behavior of steel plate shear wall systems is still unclear to structural engineering profession because of the limited amount of research and multistory experiments. Available seismic response factors are based on the observations from limited experiments and judgment. Studies related with SPSW systems can be categorized into two groups:

1. Experimental Studies

2. Numerical Studies

Although, results of the studies are not directly related to what is investigated in this thesis, they are essential for understanding the mechanics and analytical aspects of these systems.

\subsubsection{Experimental Studies}

Caccese, Elgaaly, Chen (1993)

Objective of this study was to investigate the effects of panel slenderness ratio and the type of the beam-to-column connection. For this purpose, they tested five onefourth scale models of three-story steel plate shear walls with varying plate thicknesses and beam-to column connections. First observation of this study was the dependence of the failure mode on plate thickness. It was observed that as the plate thickness increased, the failure mode was governed by column instability. Second observation was about the beam-to-column connection effect which was reported as small. 
Driver, Kulak, Kennedy, Elwi (1998)

These researchers tested large scale, four story, and single bay steel plate shear wall specimen with un-stiffened panels. The specimen had moment resisting beam to column connections which provided redundancy and increase in overstrength. In order to simulate earthquake loading equal horizontal loads were applied to the specimen in a controlled cyclic manner. Moreover, constant gravity loads were applied at each column. After thirty cycles of lateral loading most important conclusions of the experiment were:

- Excellent performance of the specimen

- Stable hysteresis curve

- Post ultimate degradation was slow and controlled

- Amount of energy dissipated was significantly greater than that shown by similar shear walls with shear type beam-to-column connections

- Column buckling was the ultimate failure of the system

Results of this experiment were used for the verification of the finite element models prepared for this thesis.

Lubell, Prion, Ventura, Rezai (2000)

In this research Lubell et al. tested two single- and one four-story steel shear wall specimens under cyclic quasi-static loading. Each specimen was a quarter scale model of a typical office building core. Apart from experimental work they also prepared analytical models by using current simplified analysis technique (tension strip model) and assessed their ability to predict the behaviour. They concluded that steel plate shear wall systems had good displacement ductility capacity and stable hysteresis behavior with desirable energy dissipation capacities. Moreover, they also 
stated that simplified analysis techniques provided good correlation with the specimen post yield strengths but did not predict the elastic stiffness under certain conditions. Finally, they asserted that current code provisions did not adequately address design issues related to multistory shear wall frames, including the effects of large overturning moments, the influence of the infill panel aspect ratio, and the potential for undesirable yielding sequences of the shear wall components.

Park, Kwack, Jeon, Kim, Choi (2007)

In this research Park et al. performed an experimental study to investigate the cyclic behavior of steel plate shear walls. Five specimens with a single bay and three stories were tested. Plate thickness, strength and compactness of the column were the main parameters that were investigated. Like the results of the other experiments they observed that well designed steel plate walls exhibited large ductility and energy dissipation capacity as well as high strength. Main conclusions of the research program were:

1. Steel plate shear walls with thin infill plates showed excellent initial stiffness, strength, and deformation capacity even though local buckling of the thin plates occurred at the early loading stage.

2. Local failure of the infill plates did not significantly affect the overall strength and deformation capacity of the system.

3. Deformation mode of the steel plate shear walls could be classified as shear dominated behavior or flexure dominated behavior.

4. If the columns were non-compact sections, the story-stiffness and strength would be reduced by early local buckling of columns.

5. The boundary columns had to be designed to resist the member forces developed by the tension-field action of the infill steel plates. 


\subsubsection{Numerical Studies}

Driver, Kulak, Kennedy, Elwi (1998)

Modeling studies related to the shear wall test conducted by the same authors mentioned in the experimental studies section were explained in this study. Finite element model and tension strip model were investigated with respect to test results. In other words, the test results were used to verify the validity of the models. Results of this study indicated that one finite element analysis that neglected second order geometric effects overestimated the stiffness of the test specimen. Thus authors recommended including geometric nonlinearities in finite element analysis of this systems which resulted in better prediction of the response of the test specimen. Moreover, authors claimed that the tension strip model gave a very good prediction of the envelope of cyclic behavior.

Berman and Bruneau (2003)

In this study the authors reviewed the recommendations for the analysis and design of steel plate shear walls and identified the instances where recommended procedures could lead to unconservative designs. In other words, ultimate capacity lower than the demand on the system. Moreover, they proposed simple equations to calculate the ultimate capacity of any type of SPSW approximately and compared their findings with the test results which showed reasonable agreement. 
Berman and Bruneau (2008)

Estimation of design loads for vertical boundary elements is one of the most complex and also one of the most significant parts of the design process of steel plate shear walls. It is very complex because finite element analysis which is not a desirable method for designers is required in order to predict actual demands on these elements. Moreover, it is very important to calculate capacity demands on these members because observations in the experimental studies showed that under capacity VBEs can result in premature failure of the system. In order to eliminate this premature failure Berman and Bruneau proposed capacity design of vertical boundary elements in this study. Moreover, they compared the moment and axial force diagrams obtained using the proposed procedure with the ones obtained from pushover analysis and showed that they agree well. Moreover, they identified the deficiencies in the approximate methods proposed in the 2005 AISC Seismic Provisions for Structural Steel Buildings. Finally, they provided an example to show how these forces could be calculated by the proposed method.

\subsection{Studies on Response Factors}

Uang (1991)

In this study Uang derived the basic formulas for establishing the response modification factor $R$ and the displacement amplification factor $C_{d}$ used in the National Earthquake Hazards Reduction Program (NEHRP) recommended provisions. Formulations of each factor were based on a typical global structural response shown in Figure 1.3. 


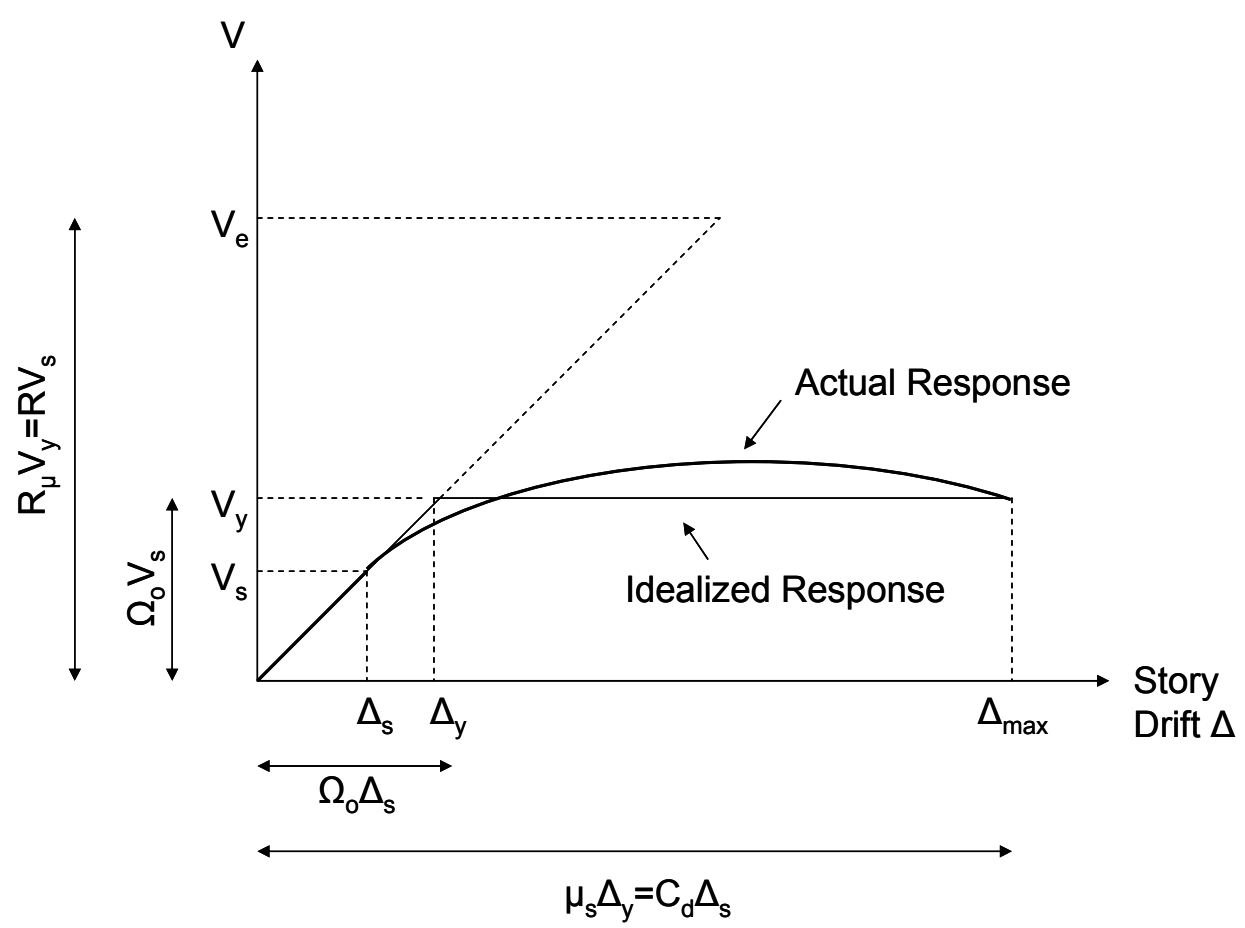

Figure 1.3: General Structural Response

In Figure 1.3:

$\mathrm{V}_{\mathrm{s}}$ : Base shear at the first significant yield

$\mathrm{V}_{\mathrm{y}}$ : Base shear at the structural collapse level

$\mathrm{V}_{\mathrm{e}}$ : Ultimate elastic base shear

$\Delta_{\mathrm{s}} \quad$ : Drift at the first significant yield

$\Delta_{\mathrm{y}}:$ Drift at the structural collapse level

$\Delta_{\max }$ : Maximum amount of drift

Based on the parameters defined above Uang presented the following formulations:

$$
\mu_{s}=\frac{\Delta_{\max }}{\Delta_{y}}, \quad R_{\mu}=\frac{V_{e}}{V_{y}}, \quad \Omega_{0}=\frac{V_{y}}{V_{s}}, \quad R=\frac{V_{e}}{V_{s}}=R_{\mu} \Omega_{0}, \quad C_{d}=\frac{\Delta_{\max }}{\Delta_{s}}=\mu_{s} \Omega_{0}
$$


Where,

$$
\begin{aligned}
& \mu_{\mathrm{s}}: \text { Ductility factor } \\
& \mathrm{R}_{\mu}: \text { Ductility reduction factor } \\
& \Omega_{\mathrm{o}}: \text { Overstrength factor } \\
& \mathrm{R}: \text { Response modification factor } \\
& \mathrm{C}_{\mathrm{d}}: \text { Displacement amplification factor }
\end{aligned}
$$

Main conclusions were:

1. Response modification factor $R$ and displacement amplification factor $C_{d}$ were functions of structural overstrength factor $\Omega_{0}$, structural ductility factor $\mu_{\mathrm{s}}$ and equivalent viscous damping ratio - effect of damping was generally included in the ductility reduction factor $R_{\mu}$.

2. Using a constant value of $\mathrm{R}$ or $\mathrm{C}_{\mathrm{d}}$ did not ensure the same level of safety against collapse for all structures. For buildings with little redundancy the structural overstrength that was relied upon by the current seismic design provisions may have been insufficient. There was a need to incorporate in the design process a method to quantify the overstrength of a structure; this overstrength should not have been less than that assumed in establishing the $\mathrm{R}$ and $\mathrm{C}_{\mathrm{d}}$ factors.

3. Values of $R$ and $C_{d}$ recommended in NEHRP were not consistent for the various structural systems. These values should have been reevaluated in a more rational manner; the basic formulas derived in this study could be used for this purpose.

4. Definition of structural ductility for multistory building structures that exhibited significant strength and stiffness deterioration was still a major obstacle for establishing $\mathrm{R}$ and $\mathrm{C}_{\mathrm{d}}$ factors. 
Miranda, Bertero (1994)

Main objective of this study was to review investigations on reduction factors which allow the estimation of lateral strengths required to control the level of inelastic deformations during strong earthquake ground motions. For this purpose, they presented strength reduction factors proposed by several investigations. Main conclusions were:

1. Except for the ideally infinitely rigid structures, allowing nonlinear hysteretic behavior to take place in the event of severe ground motions resulted in important reductions in design lateral strengths. The magnitude of these strength reductions was primarily a function of the maximum tolerable displacement ductility demand, the period of the system, and the soil conditions at the site. Other factors that may have affected the strength reduction factor were the type of hysteretic behavior, damping of the structure, and the distance to the epicenter of the earthquake. However, these factors had a lesser effect.

2. Depending on the period of vibration, strength reduction factors for systems on alluvium could be slightly higher or lower than those of systems on rock. With the exception of relatively long periods (larger than two and one half times the predominant period of the ground motion) strength reduction factors for systems on soft soil sites were significantly different from those of systems on either rock or alluvium sites. For short period (those with periods smaller than two thirds the predominant period of the ground motion), the strength reduction factor was significantly smaller than that corresponding to systems with the same period on either rock or alluvium sites. Thus, the use of strength reduction factors derived for firm sites, if used for short-period structures on soft soil sites, could lead to displacement ductility demands considerably larger than those originally intended in its design. 
3. The use of ductility-, period- and site-dependent strength reduction factors like those presented in the paper, together with estimates of the overstrength of the structure and the relationship between global and ductility demands, could lead to a more rational and transparent seismic design approach than the approach currently used in seismic codes in the United States.

\subsection{Studies on Response factors of SPSW}

Kurban and Topkaya (2009)

Kurban and Topkaya conducted a numerical study in order to evaluate seismic response factors (Response modification factor $(R)$, overstrength factor $\left(\Omega_{0}\right)$, ductility reduction factor $\left(\mathrm{R}_{\mu}\right)$, and displacement amplification $\left(\mathrm{C}_{\mathrm{d}}\right)$ factor recommended in design codes for steel plate shear walls. For this purpose, three dimensional finite element models of forty four structures which were subjected to a selected suite of earthquake records were analyzed. They considered bay width, number of stories, story mass, and steel plate thickness as the prime variables that affect the system response. Using the results of geometrically nonlinear elastic and inelastic time history analysis authors related the seismic factors to inter story drift ratio (ISDR). They claimed that overstrength present for these walls can be estimated by considering the uniform yielding mechanism and soft story mechanism and added that difference between numerical analyses was due to presence of higher mode effects. Moreover, they provided mean value, upper and lower bound equations. They concluded that these equations could be used either to estimate the amount of ISDR expected for SPSW system designed using a particular value of $\mathrm{R}$ or to find out the range of $\mathrm{R}$ values that could be used for target inter story drift level. 


\subsection{Objective and Scope of the Study}

Response factors such as the response modification, the overstrength, and the displacement amplification factors are directly used in the design of structures against earthquake loads. The recommended values for these factors are generally based on engineering judgement. Widely used design specifications such as the International Building Code (IBC) (2003), and the Eurocode (1994) recommend response factor values depending on the type of the lateral load resisting system. The response factors are categorized into two for systems with steel plate shear walls (SPSW) depending on the wall's interaction with the rest of the framing. Steel plate walls can be used as a sole lateral load resisting system or they can form a dual system with moment resisting frames. According to the IBC specification (2003), in order to qualify as a dual system, the elastic base shear resisted by the moment frame should be at least $25 \%$ of the total base shear. Systems that do not satisfy this criterion should be designed as a wall-only system with lower response factor values.

The response factors for walls without framing (wall only systems) were studied numerically by Kurban and Topkaya (2009). The work presented herein is an extension of the work conducted by them to dual systems consisting of steel plate shear walls and moment resisting frames.

The primary aim of this study is to explore the dependence of the response factors on the elastic base shear distribution between the wall and the frame. Pursuant to this goal, dual systems with different load shares between the wall and the frame were analyzed using the finite element method. Details of the dual system selection and the numerical modeling techniques are explained. The dependence of the response factors on several measures such as interstory drift, top story drift, and global structural ductility is explored. Finally, the results for dual systems with different load shares are compared. 


\section{CHAPTER 2}

\section{DESIGN, MODELING AND VERIFICATION}

A total of 40 SPSW systems were analyzed as a part of this study. The number of stories, the story mass, and the elastic base shear distribution were considered as the prime variables.

Dead plus the reduced live load was taken to be equal to $5 \mathrm{kN} / \mathrm{m}^{2}$ (metal decking and concrete slab $2.1 \mathrm{kN} / \mathrm{m}^{2}$; HVAC $0.5 \mathrm{kN} / \mathrm{m}^{2}$; steel construction $0.8 \mathrm{kN} / \mathrm{m}^{2}$; partitioning walls $0.5 \mathrm{kN} / \mathrm{m}^{2}$; floor cover $0.5 \mathrm{kN} / \mathrm{m}^{2}$; reduced live load $0.6 \mathrm{kN} / \mathrm{m}^{2}$ ). Based on the floor plans given in Figures 2.1 and 2.2, mass per story for each wall was calculated as 150 and 300 tons, respectively. 


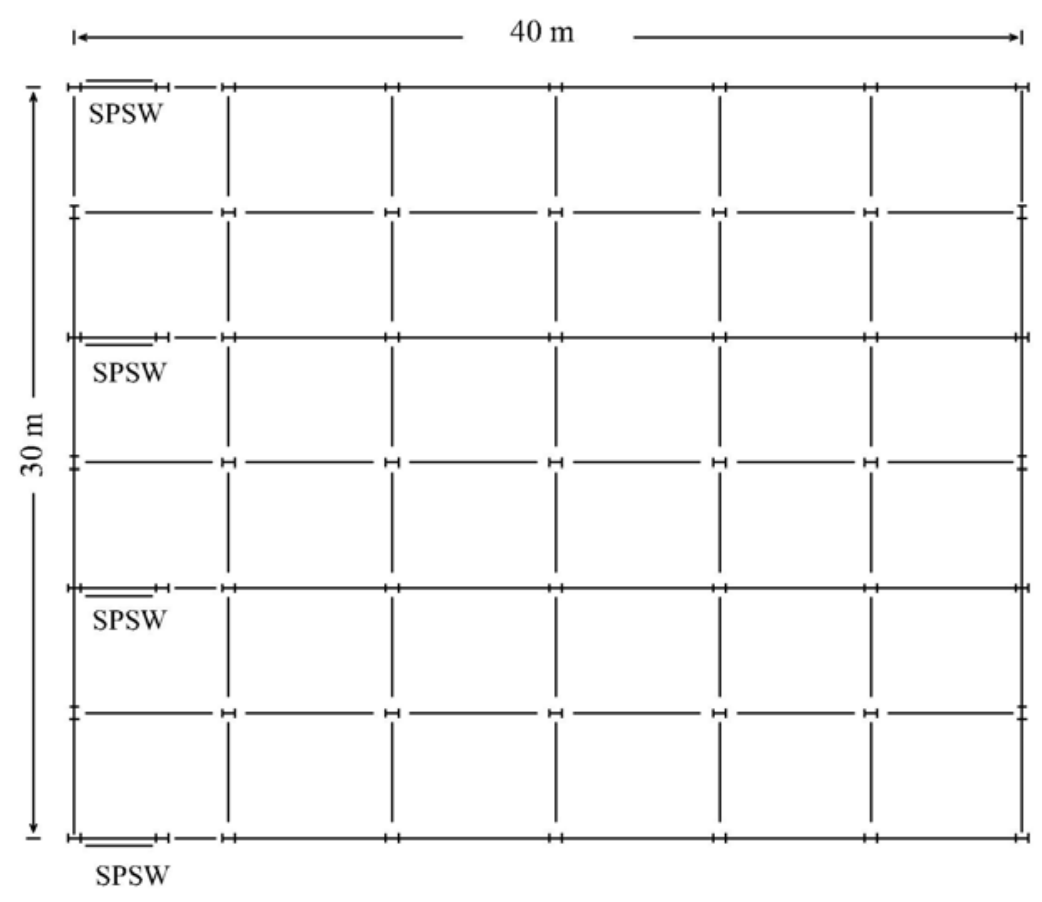

Figure 2.1: Floor Plan for 150 ton Mass per Story

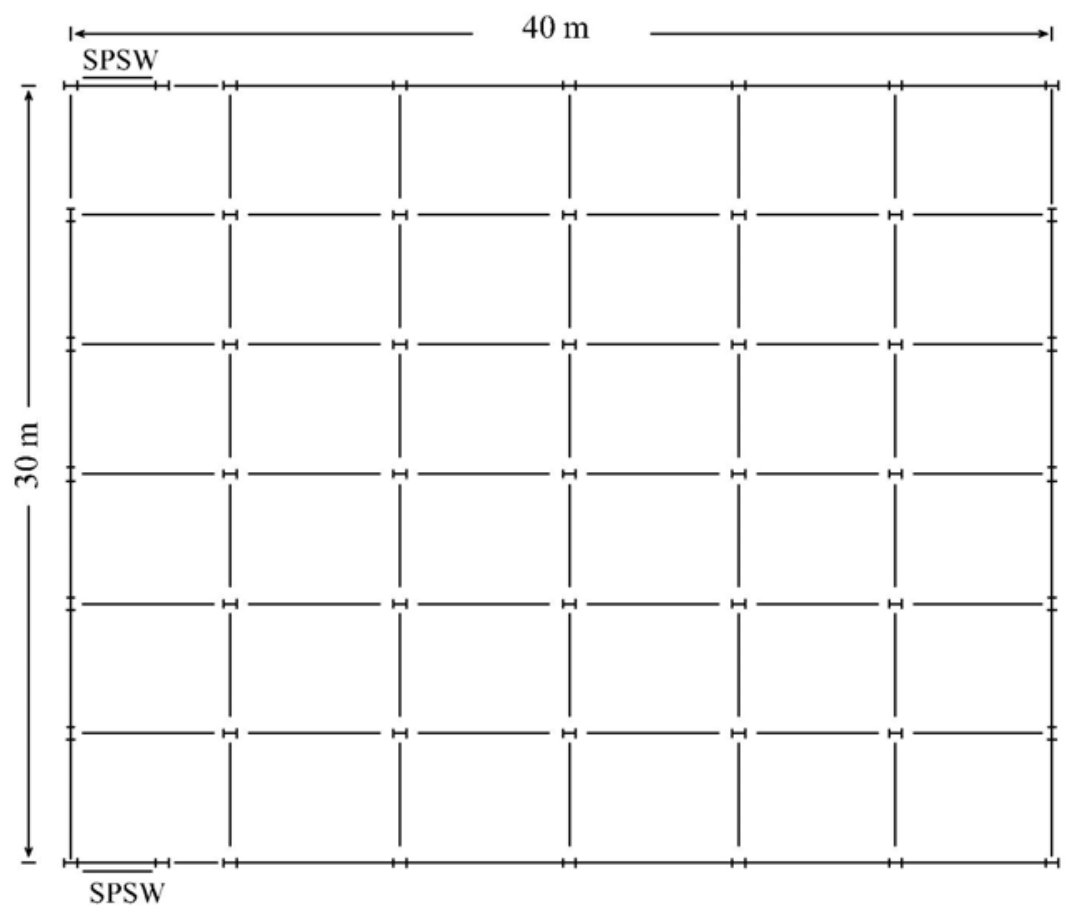

Figure 2.2: Floor Plan for 300 ton Mass per Story 


\subsection{Design of SPSW systems}

Wall-frame systems were selected such that the frame contribution to the elastic base shear resistance is $10 \%, 25 \%$, or $50 \%$ of the total base shear. Wall-only systems were also investigated for comparison purposes. Three, 6, 9, 12, and 15 story systems were analyzed to cover low to medium rise buildings in which higher mode effects are also significant. The wall systems were designed first, followed by a selection of a framing system for a particular amount of load share.

For all walls, story height was taken as $3600 \mathrm{~mm}$ (approximately) and infill plates having side dimensions of $3000 \mathrm{~mm}$ (aspect ratio of 1), a thickness of $3 \mathrm{~mm}$ and a yield strength of $200 \mathrm{MPa}$ were used at all stories. The thickness of infill plates was not reduced from bottom to the top story because thinner web plates typically require additional care and effort on the parts of fabricators and erectors.

The high-seismic design procedure explained by Sabelli and Bruneau (2007) was followed in the selection of the boundary framing. Horizontal Boundary Elements (HBEs) were designed for forces corresponding to the yielding of the infill plate. Axial forces in HBE are produced due to infill plate tension on the Vertical Boundary Element (VBE). Flexural forces are mainly due to the infill plate tension, and become zero whenever the same infill plate thickness is used for the stories above and below the HBE. However, due to the dynamic nature of the loading, different amounts of shear produced in stories above and below the HBE result in the formation of flexural forces. Because the story shears were not known in advance, the flexural force demands were calculated by considering a difference in plate thickness equal to $1.5 \mathrm{~mm}$ between the stories. Based on the axial and flexural forces produced, a W24x68 wide flange section with yield strength of $235 \mathrm{MPa}$ (S235 European steel) was selected for intermediate level HBEs. Similarly, a W24x117 section with the same strength was selected for the topmost HBE. The bottom story 
infill plate was anchored to the foundation in this study; therefore no HBE was required for that level.

Capacity design principles were used to size the VBEs. Flexural and axial forces on the VBEs were derived using the procedure outlined by Sabelli and Bruneau (2007). Basically, the axial compressive force was calculated by summing the infill plate strengths and the HBE shears. It should be mentioned that no gravity load was considered throughout this study. It was assumed that the walls and wall-frames are used for lateral loading and the gravity loads are carried by a gravity framing. Due to the change in axial load levels, the sizes of VBEs were reduced at every three stories.

All VBEs were designed considering yield strength of $355 \mathrm{MPa}$ (S355 European steel). The VBE sizes for the walls are given in Table 2.1.

Table 2.1: VBE sizes for the walls

\begin{tabular}{|c|c|c|c|c|c|}
\hline Story No & 3 Story & 6 Story & 9 Story & 12 Story & 15 Story \\
\hline $\mathbf{1}$ & $\mathrm{W} 14 \times 176$ & $\mathrm{~W} 14 \times 283$ & $\mathrm{~W} 14 \times 370$ & $\mathrm{~W} 14 \times 398$ & $\mathrm{~W} 14 \times 550$ \\
\hline $\mathbf{2}$ & $\mathrm{W} 14 \times 176$ & $\mathrm{~W} 14 \times 283$ & $\mathrm{~W} 14 \times 370$ & $\mathrm{~W} 14 \times 398$ & $\mathrm{~W} 14 \times 550$ \\
\hline $\mathbf{3}$ & $\mathrm{W} 14 \times 176$ & $\mathrm{~W} 14 \times 283$ & $\mathrm{~W} 14 \times 370$ & $\mathrm{~W} 14 \times 398$ & $\mathrm{~W} 14 \times 550$ \\
\hline $\mathbf{4}$ & - & $\mathrm{W} 14 \times 159$ & $\mathrm{~W} 14 \times 257$ & $\mathrm{~W} 14 \times 311$ & $\mathrm{~W} 14 \times 455$ \\
\hline $\mathbf{5}$ & - & $\mathrm{W} 14 \times 159$ & $\mathrm{~W} 14 \times 257$ & $\mathrm{~W} 14 \times 311$ & $\mathrm{~W} 14 \times 455$ \\
\hline $\mathbf{6}$ & - & $\mathrm{W} 14 \times 159$ & $\mathrm{~W} 14 \times 257$ & $\mathrm{~W} 14 \times 311$ & $\mathrm{~W} 14 \times 455$ \\
\hline $\mathbf{7}$ & - & - & $\mathrm{W} 14 \times 176$ & $\mathrm{~W} 14 \times 211$ & $\mathrm{~W} 14 \times 370$ \\
\hline $\mathbf{8}$ & - & - & $\mathrm{W} 14 \times 176$ & $\mathrm{~W} 14 \times 211$ & $\mathrm{~W} 14 \times 370$ \\
\hline $\mathbf{9}$ & - & - & $\mathrm{W} 14 \times 176$ & $\mathrm{~W} 14 \times 211$ & $\mathrm{~W} 14 \times 370$ \\
\hline $\mathbf{1 0}$ & - & - & - & $\mathrm{W} 14 \times 176$ & $\mathrm{~W} 14 \times 257$ \\
\hline $\mathbf{1 1}$ & - & - & - & $\mathrm{W} 14 \times 176$ & $\mathrm{~W} 14 \times 257$ \\
\hline $\mathbf{1 2}$ & - & - & - & $\mathrm{W} 14 \times 176$ & $\mathrm{~W} 14 \times 257$ \\
\hline $\mathbf{1 3}$ & - & - & - & - & $\mathrm{W} 14 \times 176$ \\
\hline $\mathbf{1 4}$ & - & - & - & - & $\mathrm{W} 14 \times 176$ \\
\hline $\mathbf{1 5}$ & - & - & - & - & $\mathrm{W} 14 \times 176$ \\
\hline
\end{tabular}


Three frames were selected for each wall depending on the elastic base shear distribution. In order to provide a fair comparison between the systems, several parameters were kept constant during the frame member selection process. In all frames, beams were selected from W12 sections while columns were selected from W14 sections. The sum of the moment capacity of the beams was smaller than that of columns at each rigid beam-to-column connection, ensuring weak-beam strongcolumn design. All beams and columns were assumed to have a yield strength of $235 \mathrm{MPa}$. Five bay frames with $6 \mathrm{~m}$ equal bay spacing were considered.

In this study, the wall-frame interaction was considered by separately modeling the wall and the frame and equalizing the displacements at each story. Therefore, it was assumed that a link beam with shear connections at both ends is present between the wall and the frame. This kind of a modeling assumption enables to precisely determine the base shear resistance provided by the wall and the frame.

A preliminary structural analysis model employing beam and truss elements were used for the selection of the frame element sizes. The wall was modeled using Xdiagonals and all wall-frames were subjected to a triangular lateral load pattern. Frame element sizes were determined using a trial and error procedure. In order to represent the possible changes in stiffness through the height of the structure, frame element sizes were reduced at every three stories. Usually the sizes of the sections were reduced gradually for preventing a stiffness irregularity. Strictly speaking the selection of frame sizes was dependent on stiffness of the elements rather than their strength. In other words, frame element sizes were increased to satisfy the base shear distribution criterion. For all wall-frame systems, the infill plate of the wall yields first before any yielding of the frame beams. The final beam and column sizes used in this study are given in Table 2.2, 2.3, 2.4, 2.5 and 2.6. In these tables: 
Table 2.2: The final beam and column sizes (3 Story)

\begin{tabular}{|c|c|c|c|c|c|c|}
\hline $\begin{array}{c}\text { Elastic Shear } \\
\text { Dist. }\end{array}$ & \multicolumn{2}{|c|}{$\mathbf{5 0 \%}$ W - 50 \% F } & \multicolumn{2}{c|}{$\mathbf{7 5 \%}$ W - 25 \% F } & \multicolumn{2}{c|}{$\mathbf{9 0 \%}$ W - 10\% F } \\
\hline Story No & Beam & Column & Beam & Column & Beam & Column \\
\hline $\mathbf{1}$ & $\mathrm{W} 12 \times 305$ & $\mathrm{~W} 14 \times 342$ & $\mathrm{~W} 12 \times 136$ & $\mathrm{~W} 14 \times 132$ & $\mathrm{~W} 12 \times 40$ & $\mathrm{~W} 14 \times 48$ \\
\hline $\mathbf{2}$ & $\mathrm{W} 12 \times 305$ & $\mathrm{~W} 14 \times 342$ & $\mathrm{~W} 12 \times 136$ & $\mathrm{~W} 14 \times 132$ & $\mathrm{~W} 12 \times 40$ & $\mathrm{~W} 14 \times 48$ \\
\hline $\mathbf{3}$ & $\mathrm{W} 12 \times 305$ & $\mathrm{~W} 14 \times 342$ & $\mathrm{~W} 12 \times 136$ & $\mathrm{~W} 14 \times 132$ & $\mathrm{~W} 12 \times 40$ & $\mathrm{~W} 14 \times 48$ \\
\hline
\end{tabular}

Table 2.3: The final beam and column sizes (6 Story)

\begin{tabular}{|c|c|c|c|c|c|c|}
\hline $\begin{array}{c}\text { Elastic Shear } \\
\text { Dist. }\end{array}$ & \multicolumn{2}{|c|}{$\mathbf{5 0 \%}$ W - 50 \% F } & \multicolumn{2}{|c|}{$\mathbf{7 5 \%}$ W - 25\% F } & \multicolumn{2}{c|}{$\mathbf{9 0 \%}$ W - 10\% F } \\
\hline Story No & Beam & Column & Beam & Column & Beam & Column \\
\hline $\mathbf{1}$ & $\mathrm{W} 12 \times 252$ & $\mathrm{~W} 14 \times 455$ & $\mathrm{~W} 12 \times 136$ & $\mathrm{~W} 14 \times 159$ & $\mathrm{~W} 12 \times 50$ & $\mathrm{~W} 14 \times 53$ \\
\hline $\mathbf{2}$ & $\mathrm{W} 12 \times 252$ & $\mathrm{~W} 14 \times 455$ & $\mathrm{~W} 12 \times 136$ & $\mathrm{~W} 14 \times 159$ & $\mathrm{~W} 12 \times 50$ & $\mathrm{~W} 14 \times 53$ \\
\hline $\mathbf{3}$ & $\mathrm{W} 12 \times 252$ & $\mathrm{~W} 14 \times 455$ & $\mathrm{~W} 12 \times 136$ & $\mathrm{~W} 14 \times 159$ & $\mathrm{~W} 12 \times 50$ & $\mathrm{~W} 14 \times 53$ \\
\hline $\mathbf{4}$ & $\mathrm{W} 12 \times 230$ & $\mathrm{~W} 14 \times 311$ & $\mathrm{~W} 12 \times 106$ & $\mathrm{~W} 14 \times 120$ & $\mathrm{~W} 12 \times 45$ & $\mathrm{~W} 14 \times 48$ \\
\hline $\mathbf{5}$ & $\mathrm{W} 12 \times 230$ & $\mathrm{~W} 14 \times 311$ & $\mathrm{~W} 12 \times 106$ & $\mathrm{~W} 14 \times 120$ & $\mathrm{~W} 12 \times 45$ & $\mathrm{~W} 14 \times 48$ \\
\hline $\mathbf{6}$ & $\mathrm{W} 12 \times 230$ & $\mathrm{~W} 14 \times 311$ & $\mathrm{~W} 12 \times 106$ & $\mathrm{~W} 14 \times 120$ & $\mathrm{~W} 12 \times 45$ & $\mathrm{~W} 14 \times 48$ \\
\hline
\end{tabular}

Table 2.4: The final beam and column sizes (9 Story)

\begin{tabular}{|c|c|c|c|c|c|c|}
\hline $\begin{array}{c}\text { Elastic } \\
\text { Shear Dist. }\end{array}$ & \multicolumn{2}{|c|}{$\mathbf{5 0 \%}$ W - 50 \% F } & \multicolumn{2}{|c|}{$\mathbf{7 5 \%}$ W - 25 \% F } & \multicolumn{2}{|c|}{$\mathbf{9 0 \%}$ W - 10\% F } \\
\hline Story No & Beam & Column & Beam & Column & Beam & Column \\
\hline $\mathbf{1}$ & $\mathrm{W} 12 \times 279$ & $\mathrm{~W} 14 \times 398$ & $\mathrm{~W} 12 \times 152$ & $\mathrm{~W} 14 \times 159$ & $\mathrm{~W} 12 \times 58$ & $\mathrm{~W} 14 \times 61$ \\
\hline $\mathbf{2}$ & $\mathrm{W} 12 \times 279$ & $\mathrm{~W} 14 \times 398$ & $\mathrm{~W} 12 \times 152$ & $\mathrm{~W} 14 \times 159$ & $\mathrm{~W} 12 \times 58$ & $\mathrm{~W} 14 \times 61$ \\
\hline $\mathbf{3}$ & $\mathrm{W} 12 \times 279$ & $\mathrm{~W} 14 \times 398$ & $\mathrm{~W} 12 \times 152$ & $\mathrm{~W} 14 \times 159$ & $\mathrm{~W} 12 \times 58$ & $\mathrm{~W} 14 \times 61$ \\
\hline $\mathbf{4}$ & $\mathrm{W} 12 \times 252$ & $\mathrm{~W} 14 \times 342$ & $\mathrm{~W} 12 \times 120$ & $\mathrm{~W} 14 \times 120$ & $\mathrm{~W} 12 \times 50$ & $\mathrm{~W} 14 \times 53$ \\
\hline $\mathbf{5}$ & $\mathrm{W} 12 \times 252$ & $\mathrm{~W} 14 \times 342$ & $\mathrm{~W} 12 \times 120$ & $\mathrm{~W} 14 \times 120$ & $\mathrm{~W} 12 \times 50$ & $\mathrm{~W} 14 \times 53$ \\
\hline $\mathbf{6}$ & $\mathrm{W} 12 \times 252$ & $\mathrm{~W} 14 \times 342$ & $\mathrm{~W} 12 \times 120$ & $\mathrm{~W} 14 \times 120$ & $\mathrm{~W} 12 \times 50$ & $\mathrm{~W} 14 \times 53$ \\
\hline $\mathbf{7}$ & $\mathrm{W} 12 \times 210$ & $\mathrm{~W} 14 \times 311$ & $\mathrm{~W} 12 \times 106$ & $\mathrm{~W} 14 \times 109$ & $\mathrm{~W} 12 \times 45$ & $\mathrm{~W} 14 \times 48$ \\
\hline $\mathbf{8}$ & $\mathrm{W} 12 \times 210$ & $\mathrm{~W} 14 \times 311$ & $\mathrm{~W} 12 \times 106$ & $\mathrm{~W} 14 \times 109$ & $\mathrm{~W} 12 \times 45$ & $\mathrm{~W} 14 \times 48$ \\
\hline $\mathbf{9}$ & $\mathrm{W} 12 \times 210$ & $\mathrm{~W} 14 \times 311$ & $\mathrm{~W} 12 \times 106$ & $\mathrm{~W} 14 \times 109$ & $\mathrm{~W} 12 \times 45$ & $\mathrm{~W} 14 \times 48$ \\
\hline
\end{tabular}


Table 2.5: The final beam and column sizes (12 Story)

\begin{tabular}{|c|c|c|c|c|c|c|}
\hline \multirow{2}{*}{$\begin{array}{c}\text { Elastic } \\
\text { Shear Dist. } \\
\text { Story No }\end{array}$} & \multicolumn{2}{|c|}{$50 \% W-50 \% F$} & \multicolumn{2}{|c|}{$75 \% W-25 \% F$} & \multicolumn{2}{|c|}{$90 \% W-10 \% F$} \\
\hline & Beam & Column & Beam & Column & Beam & Column \\
\hline 1 & W12x279 & W14x398 & $\mathrm{W} 12 \times 152$ & & W12x53 & \\
\hline 2 & 279 & W14x398 & W12x152 & W14x & & $N 14 \times 68$ \\
\hline 3 & W12x & W14x398 & W12x152 & W14x & W12x53 & $x 68$ \\
\hline 4 & W12: & $\mathrm{W} 14 \times 342$ & W12x & W14r & W12 & $\times 61$ \\
\hline 5 & W12: & $\mathrm{W} 14 \times 342$ & $\mathrm{~W} 12 \times 120$ & & & \\
\hline 6 & 52 & W14x342 & & & & \\
\hline 7 & & & W12x106 & & & \\
\hline 8 & $\mathrm{~W} 12 \times 230$ & W14x311 & W12x106 & & & $\mathrm{W} 14 \times 53$ \\
\hline 9 & $\mathrm{~W} 12 \times 230$ & $\mathrm{~W} 14 \times 311$ & W12x106 & W14x109 & & W14x53 \\
\hline 10 & $\mathrm{~W} 12 \times 210$ & W14x283 & W12x96 & W14x176 & $\mathrm{W} 12 \times 40$ & $\mathrm{~W} 14 \times 48$ \\
\hline 11 & $\mathrm{~W} 12 \times 210$ & W14x283 & W12x96 & W14x176 & $\mathrm{W} 12 \times 40$ & $\mathrm{~W} 14 \times 48$ \\
\hline 12 & $W 12 \times 210$ & W14x283 & W12x96 & W14x176 & $\mathrm{W} 12 \mathrm{x} 40$ & $\mathrm{~W} 14 \times 48$ \\
\hline
\end{tabular}

Table 2.6: The final beam and column sizes (15 Story)

\begin{tabular}{|c|c|c|c|c|c|c|}
\hline \multirow{2}{*}{$\begin{array}{c}\text { Elastic } \\
\text { Shear Dist. } \\
\text { Story No }\end{array}$} & \multicolumn{2}{|c|}{$50 \% W-50 \%$ F } & \multicolumn{2}{|c|}{$75 \% W-25 \% F$} & \multicolumn{2}{|c|}{$90 \% W-10 \% F$} \\
\hline & Beam & Column & Beam & Column & Beam & Column \\
\hline 1 & W12x336 & W14x455 & W12x136 & W14x193 & W12X79 & $\mathrm{W} 14 \times 90$ \\
\hline 2 & W12x336 & W14x & W12x136 & & $\mathrm{W} 12 \times 79$ & \\
\hline 3 & W12x336 & W14r & W12 & & $\mathrm{W} 12$ & \\
\hline 4 & W12x305 & W14x426 & $\mathrm{W} 12 \times 120$ & 120 & W12X72 & \\
\hline 5 & W12x305 & W14x426 & $\mathrm{W} 12 \times 120$ & 120 & $\mathrm{~W} 12$ & \\
\hline 6 & W12x305 & W14x426 & W12x120 & W14x & W12x72 & $x 82$ \\
\hline 7 & W12x279 & W14x398 & W12x106 & W14x & W12x65 & $\mathrm{W} 14 \times 74$ \\
\hline 8 & 279 & W14x398 & W12x106 & 109 & & $x 74$ \\
\hline 9 & W12x279 & W14x398 & W12x106 & 109 & & \\
\hline 10 & & & & & & \\
\hline 11 & & $\mathrm{~W} 14 \times 370$ & & & $\mathrm{~W} 12 \times 58$ & \\
\hline 12 & $\mathrm{~W} 12 \times 252$ & $\mathrm{~W} 14 \times 370$ & W12x96 & & $\mathrm{W} 12 \times 58$ & \\
\hline 13 & $\mathrm{~W} 12 \times 230$ & W14x342 & & $\mathrm{W} 14 \times 90$ & W12x53 & \\
\hline 14 & W12x230 & W14x342 & W12x87 & $\mathrm{W} 14 \times 90$ & $\mathrm{~W} 12 \times 53$ & W14x61 \\
\hline 15 & $\mathrm{~W} 12 \times 230$ & W14x342 & W12x87 & $\mathrm{W} 14 \times 90$ & W12x53 & W14x61 \\
\hline
\end{tabular}


For the details of the design process and example designs one can refer to Sabelli and Bruneau (2007). Design and analysis processes followed in this study are summarized in the flow charts given in Figure 2.3 and 2.4. Both flow charts are figurative explanation of the steps followed in the study. Only difference is, flow chart in Figure 2.3 is the compact version of the other.

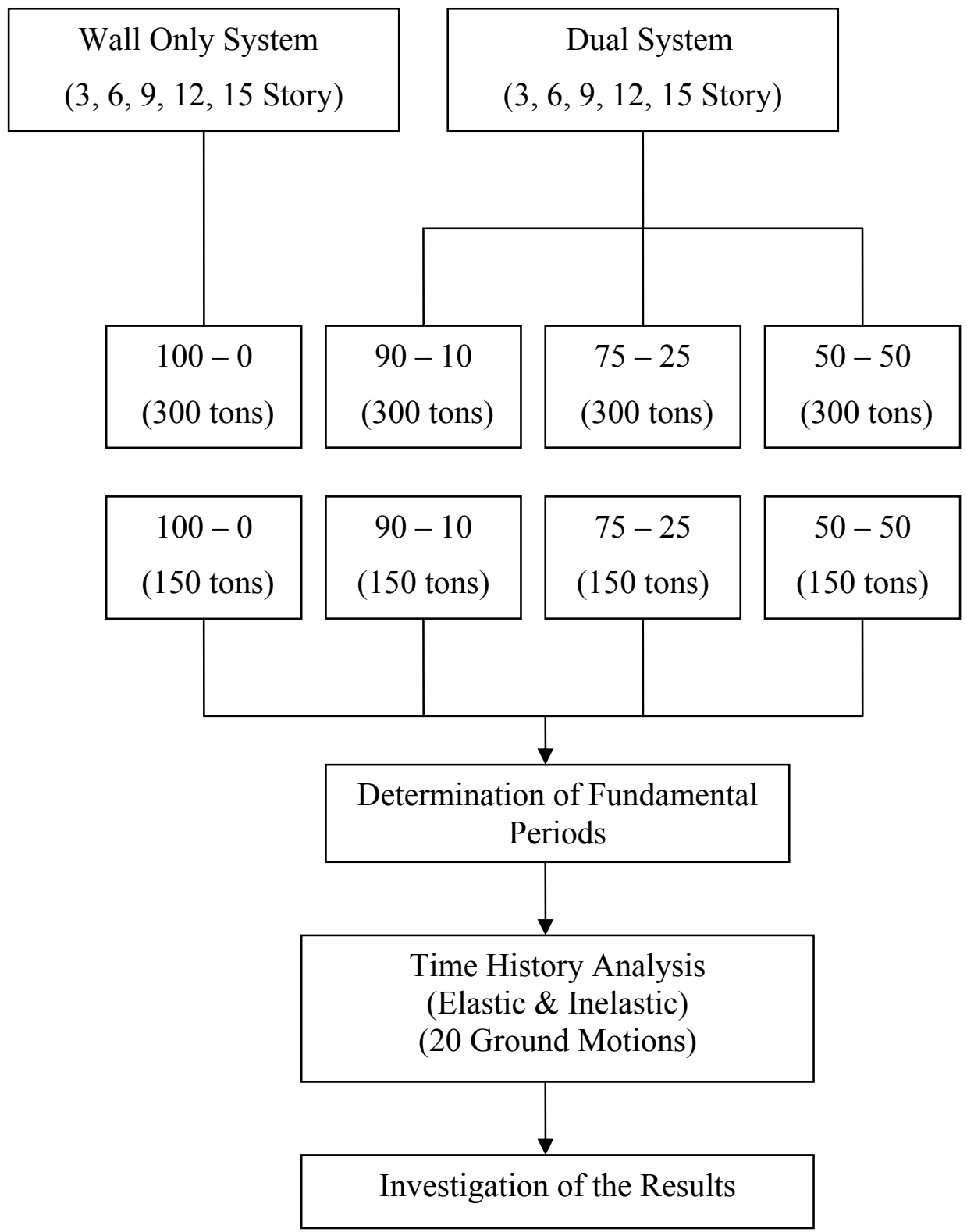

Figure 2.3: The Steps Followed in the Study (Compact Version) 


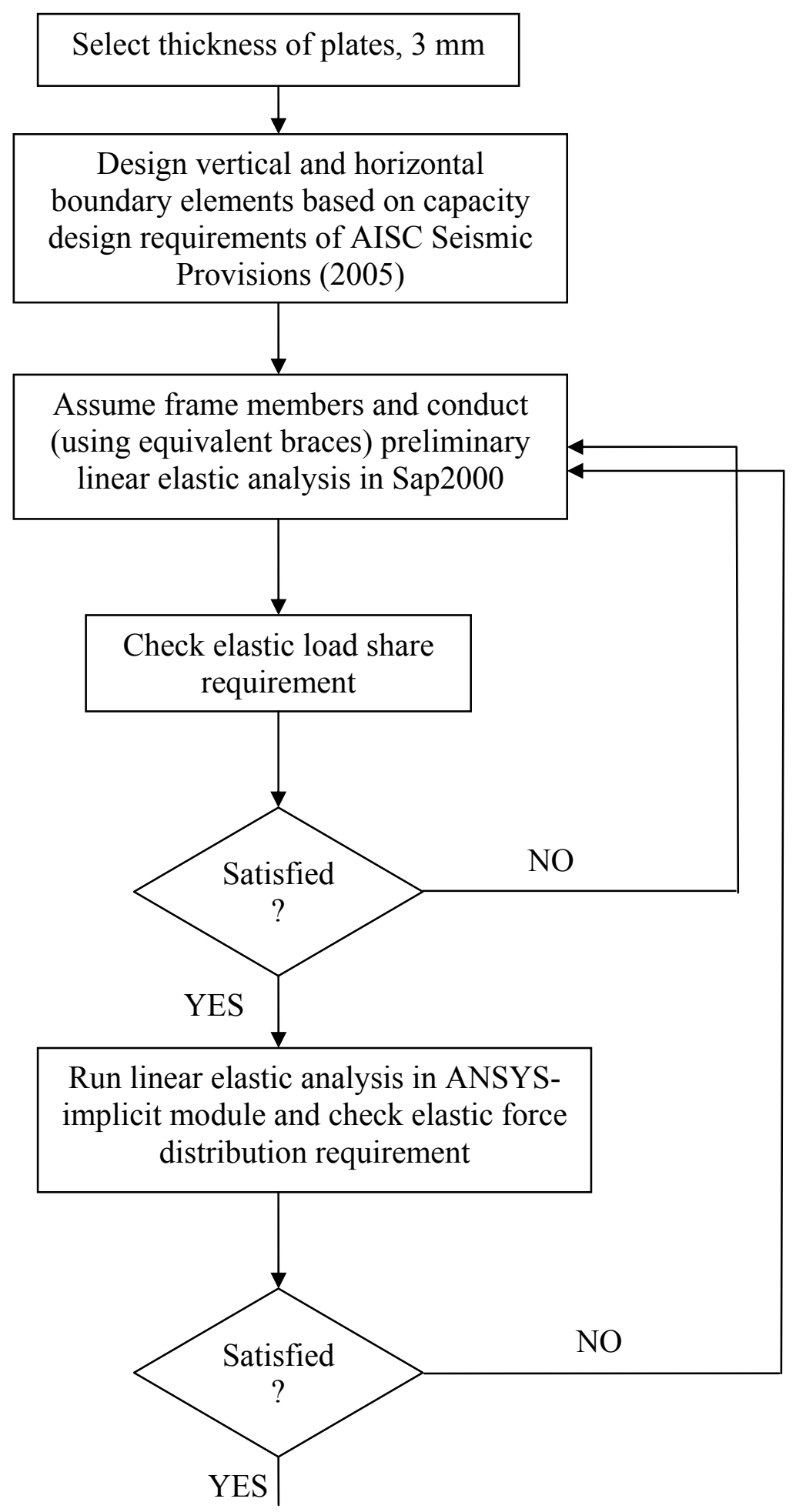


Conduct eigenvalue analysis using ANSYSImplicit Module and determine fundamental period of the structure for time history analysis

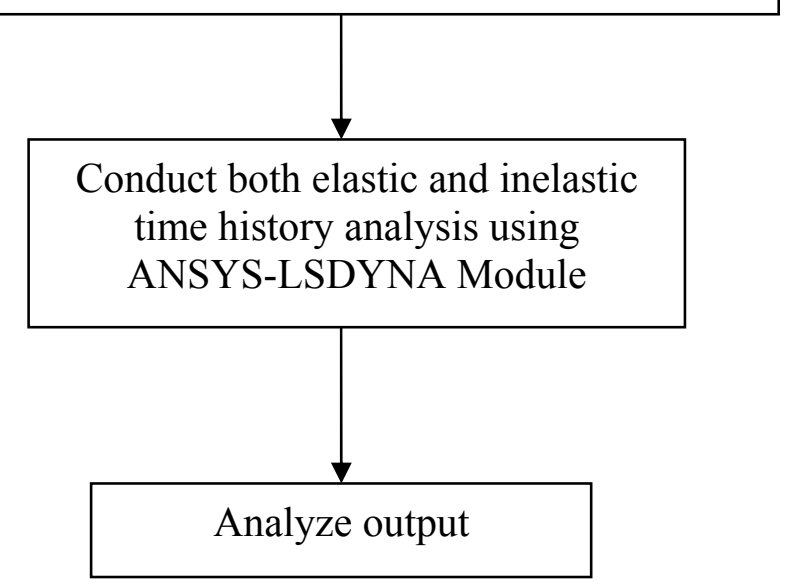

Figure 2.4: The Steps Followed in the Study (Detailed Version)

\subsection{Selection of Ground Motions}

In order to include variations in the ground motion characteristics, 20 earthquake records were selected in the numerical investigation. Earthquake records with different intensities are expected to produce different levels of ductility demands (such as interstory drift) on a particular wall system. Therefore, earthquake records having peak acceleration values ranging between $0.141 \mathrm{~g}$ and $1.778 \mathrm{~g}$ were selected to cover a wide range of peak accelerations. Details of the earthquake records are given in Table 2.7. Most of the records were recorded in alluvium sites. The suite of ground motions includes both near-field and far field records. 


\begin{tabular}{|c|c|c|c|c|c|c|c|c|c|c|c|c|c|c|c|c|c|c|c|c|c|}
\hline 良 & $\stackrel{?}{\stackrel{?}{6}}$ & $\underset{+}{\stackrel{\gamma}{+}}$ & $\begin{array}{l}\stackrel{P}{a} \\
\stackrel{I}{I}\end{array}$ & $\stackrel{ }{\hat{i}}$ & $\begin{array}{l}\hat{\sigma} \\
\infty \\
\infty \\
\sim\end{array}$ & $\begin{array}{l}0 \\
\stackrel{0}{2}\end{array}$ & & 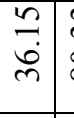 & 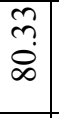 & \begin{tabular}{|l|}
$\stackrel{0}{0}$ \\
$\dot{f}$ \\
$\dot{f}$
\end{tabular} & \begin{tabular}{|l|}
$\vec{a}$ \\
$\dot{g}$
\end{tabular} & \begin{tabular}{|l|l|}
\multirow{2}{*}{} & \\
$i$ & \\
$i$
\end{tabular} & \begin{tabular}{l|l}
\multirow{2}{*}{} & $\vdots$ \\
$\dot{\infty}$ & \\
\end{tabular} & 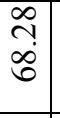 & \begin{tabular}{|l|}
\multirow{2}{n}{} \\
$\tilde{n}$ \\
$\infty$ \\
$\infty$
\end{tabular} & $\begin{array}{l}\exists \\
\vec{n}\end{array}$ & \begin{tabular}{|l|l}
\multirow{2}{n}{} & \\
$\infty$ & \\
$\infty$ & \\
$n$
\end{tabular} & $\begin{array}{l}8 \\
\dot{8} \\
\stackrel{0}{\circ}\end{array}$ & \begin{tabular}{|l|} 
\\
$\tilde{a}$ \\
$\dot{\infty}$ \\
\end{tabular} & \begin{tabular}{|l|}
$\hat{1}$ \\
$\dot{0}$ \\
$\infty$
\end{tabular} & $\stackrel{0}{0}$ \\
\hline త્త & $\underset{0}{\vec{\sigma}}$ & $\frac{n}{n}$ & 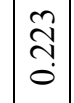 & $\frac{\Delta}{m}$ & 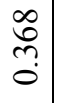 & $\begin{array}{l}n \\
\vdots \\
o \\
o\end{array}$ & & \begin{tabular}{l|l}
\multirow{2}{f}{} \\
$\stackrel{0}{0}$
\end{tabular} & 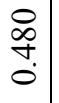 & $\begin{array}{l}m \\
\tilde{n} \\
0\end{array}$ & $\mid \begin{array}{l}0 \\
n \\
n \\
0\end{array}$ & $\left|\begin{array}{l}n \\
0 \\
0 \\
0\end{array}\right|$ & $\begin{array}{l}\overparen{J} \\
\stackrel{0}{0} \\
0\end{array}$ & $\begin{array}{l}\tilde{\hat{b}} \\
\dot{0}\end{array}$ & $\begin{array}{l}\mathbb{J} \\
\dot{b} \\
0 \\
0\end{array}$ & $\begin{array}{c}\hat{N} \\
\hat{0}\end{array}$ & 总 & $\hat{\partial}$ & $\mid \begin{array}{l}0 \\
0 \\
0 \\
-1\end{array}$ & 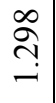 & $\stackrel{\infty}{\stackrel{\infty}{\stackrel{2}{n}}}$ \\
\hline 己ิ & $\begin{array}{l}0 \\
i \\
i\end{array}$ & $\stackrel{\infty}{=}$ & $\mid \begin{array}{c}1 \\
b \\
\dot{f}\end{array}$ & $\vec{m}$ & $\hat{\mathrm{I}}$ & $\overrightarrow{\dot{\sigma}}$ & & $\begin{array}{l}\ddot{g} \\
\ddot{g}\end{array}$ & $\begin{array}{l}0 \\
\infty \\
\infty\end{array}$ & $\stackrel{?}{\stackrel{\sim}{ \pm}}$ & $\begin{array}{c}\sim \\
i \\
i n\end{array}$ & $\vec{m}$ & $\ddot{\ddot{n}}$ & $\stackrel{\sim}{-}$ & $\stackrel{\sim}{-}$ & $\stackrel{?}{ \pm}$ & $\begin{array}{l}n \\
i \\
n\end{array}$ & $\tilde{a}$ & & $\because$ & $\hat{\sigma}$ \\
\hline$\sum$ & $\tilde{n}$ & $\overrightarrow{6}$ & $\hat{\sigma}$ & $\tilde{\sigma}$ & $\hat{6}$ & $\overrightarrow{6}$ & & -1 & $\tilde{6}$ & $\tilde{\sigma}$ & 年 & $\begin{array}{l}0 \\
r \\
\end{array}$ & $r$ & $\hat{\sigma}$ & ఠ̧ & $\tilde{6}$ & $\because$ & $\hat{6}$ & & 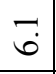 & 。 \\
\hline 施 & 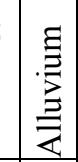 & 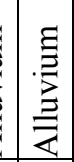 & 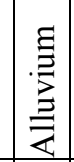 & 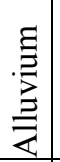 & 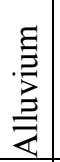 & 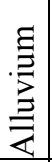 & 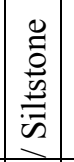 & 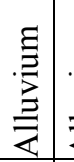 & 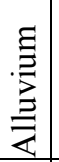 & 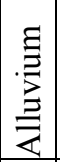 & 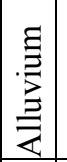 & $\mid \begin{array}{l}0 \\
\tilde{n} \\
0 \\
n \\
2\end{array}$ & 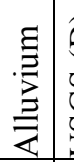 & $\begin{array}{l}\widehat{\theta} \\
\Omega \\
0 \\
\tilde{D} \\
\end{array}$ & $\begin{array}{l}\widehat{\theta} \\
\tilde{D} \\
\mathscr{D} \\
\partial\end{array}$ & 志 & $\overline{\bar{\sigma}}$ & 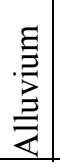 & 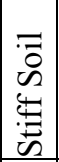 & 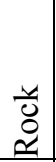 & 当 \\
\hline 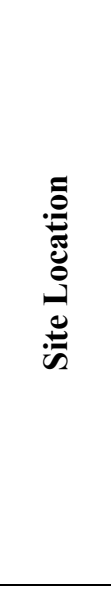 & 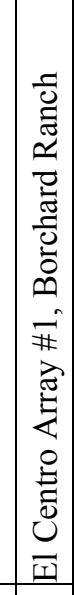 & 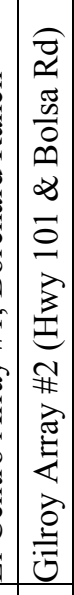 & 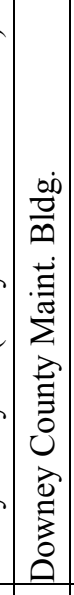 & 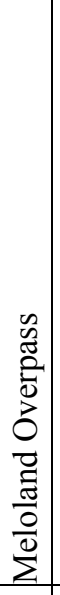 & 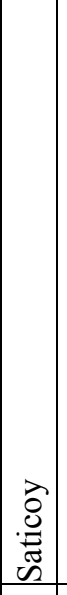 & 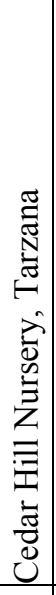 & & 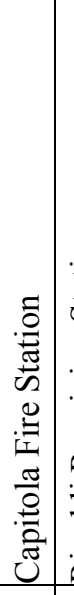 & 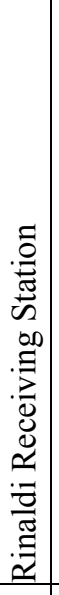 & 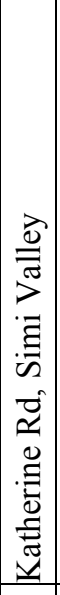 & 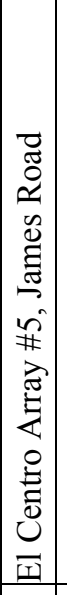 & 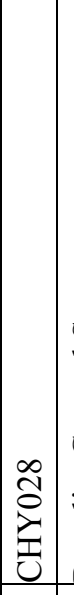 & 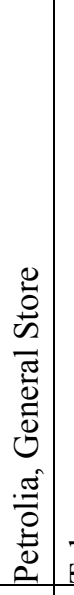 & 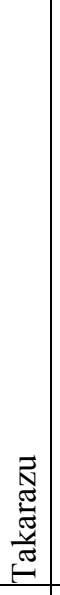 & 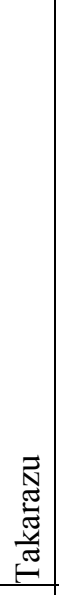 & 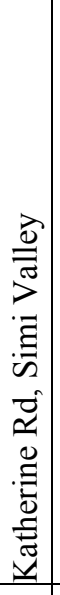 & . & 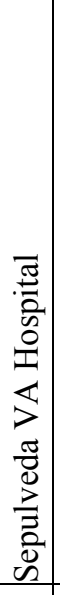 & 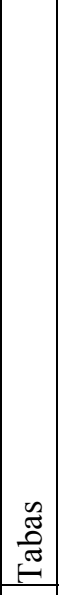 & 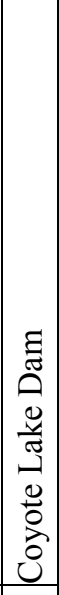 & 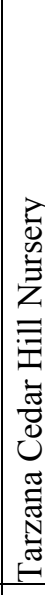 \\
\hline 气ี๊ & 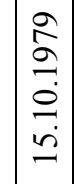 & 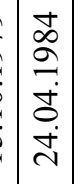 & 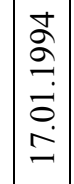 & $\begin{array}{l}\stackrel{2}{\hat{\sigma}} \\
\stackrel{0}{0} \\
\underline{n} \\
=\end{array}$ & 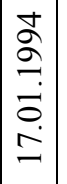 & $\begin{array}{l}\hat{\infty} \\
\sigma \\
0 \\
0 \\
\dot{0}\end{array}$ & & 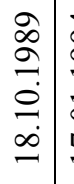 & 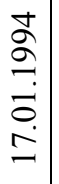 & 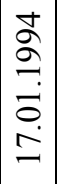 & 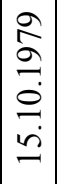 & 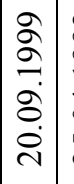 & 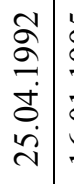 & $\begin{array}{l}2 \\
2 \\
\sigma \\
\dot{0} \\
\dot{0} \\
-\end{array}$ & $\begin{array}{l}\stackrel{n}{\sigma} \\
\sigma \\
\dot{0} \\
0 \\
-\end{array}$ & $\begin{array}{l}\vec{\sigma} \\
\sigma \\
\dot{\Xi} \\
\dot{0} \\
=\end{array}$ & 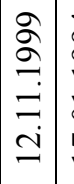 & 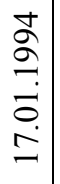 & $\mid$\begin{tabular}{c|}
$\infty$ \\
$\hat{\sigma}$ \\
\hdashline \\
$\dot{8}$ \\
0 \\
0 \\
-1
\end{tabular} & 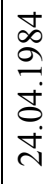 & 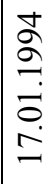 \\
\hline$\stackrel{\Xi}{E}$ & 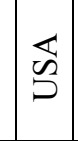 & $\begin{array}{l}\mathbb{2} \\
\Omega \\
\Omega\end{array}$ & $\mid \begin{array}{l}\ll \\
\widehat{D}\end{array}$ & 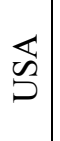 & $\begin{array}{l}\overleftrightarrow{n} \\
\rho\end{array}$ & $\begin{array}{l}\mathbb{2} \\
\text { D } \\
.\end{array}$ & & $\begin{array}{l}\overleftrightarrow{\sim} \\
\widetilde{D}\end{array}$ & 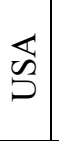 & $\begin{array}{l}\mathbb{\pi} \\
\sigma \\
D\end{array}$ & $\begin{array}{l}\mathbb{N} \\
\partial \\
D\end{array}$ & 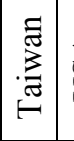 & $\underset{\mathscr{D}}{\mathbb{D}}$ & 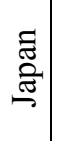 & 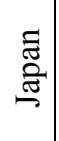 & 峁 & 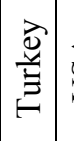 & 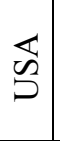 & $\underset{\Xi}{\Xi}$ & 岕 & 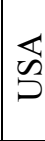 \\
\hline 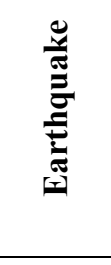 & 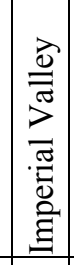 & 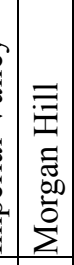 & 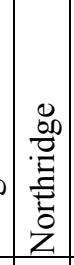 & 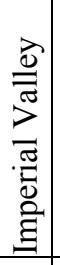 & 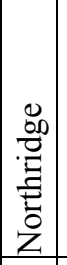 & 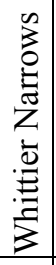 & & 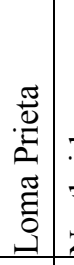 & 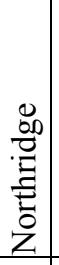 & 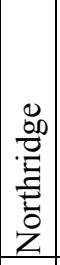 & 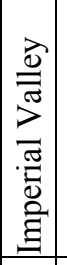 & 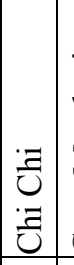 & $\begin{array}{l}0 \\
.0 \\
0 \\
0 \\
\frac{0}{0} \\
\sum_{0} \\
0 \\
0 \\
0 \\
0\end{array}$ & $\begin{array}{l}0 \\
0 \\
0 \\
1 \\
\end{array}$ & 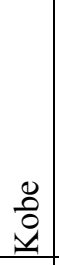 & 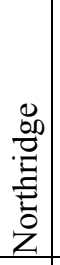 & : & 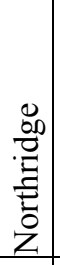 & \begin{tabular}{|l|}
0 \\
$\tilde{0}$ \\
$\tilde{0}$ \\
$\tilde{E}$ \\
\end{tabular} & 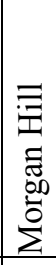 & 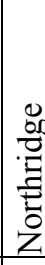 \\
\hline 壳泀 & - & $N$ & $m$ & $\nabla$ & in & 0 & & - & $\infty$ & $a$ & 잉 & $\exists$ & $\simeq$ & 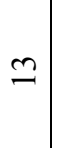 & \pm & 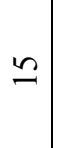 & $\stackrel{0}{-}$ & $=$ & $\infty$ & 2 & ㄱ. \\
\hline
\end{tabular}


In order to make a fair comparison of the elastic and inelastic structural response, ground motions were selected such that the base shear demand is higher than the base shear at the first significant yield $\left(V_{s}\right)$ of the structure.

The base shear at the first significant yield was found by

$$
V_{s}=\left(\frac{1}{1-\xi}\right) 0.5 F_{y} L_{c f} t_{w}
$$

Where,

$\mathrm{F}_{\mathrm{y}}:$ Yield stress of infill plate

$\mathrm{t}_{\mathrm{w}}$ : Thickness of the infill plate

$\mathrm{L}_{\mathrm{cf}}$ : Clear distance between VBE flanges

$\xi$ : Ratio of elastic base shear resisted by the frame to the total elastic base shear

Equation 2 is similar to the nominal shear capacity expression given in the AISC Seismic Provisions for Steel Buildings (2005). The AISC expression also accounts for the angle of the tension field. In the present study, the contribution of tension field angle to the capacity expression was neglected. In general, for most of these systems, the angle of inclination of the tension field is above $40^{\circ}$, which in turn results in a negligible decrease in capacity on the order of 2 percent (Sabouri-Ghomi et al, 2005). Majority of the wall shear is carried by the infill plate when the wall system remains elastic. Therefore, the contribution of the SPSW boundary framing to the lateral load carrying capacity was neglected in Equation 2. The resulting base shear values at the first significant yield are given in Table 2.8. 
Table 2.8: Base shear values at the first significant yield $\left(\mathrm{V}_{\mathrm{s}}\right)$

\begin{tabular}{|c|c|}
\hline $\begin{array}{c}\text { Elastic Base Shear } \\
\text { Distribution }\end{array}$ & $\begin{array}{c}\text { Design Base } \\
\text { Shear }(\mathrm{kN})\end{array}$ \\
\hline $100-0$ & 900 \\
\hline $90-10$ & 1000 \\
\hline $75-25$ & 1200 \\
\hline $50-50$ & 1800 \\
\hline
\end{tabular}

The design base acceleration (DBA) for each structure was obtained by normalizing the base shear at the first significant yield $\left(V_{s}\right)$ with the reactive mass. The spectral accelerations of the selected records for $2 \%$ damping are compared against the design base accelerations (DBAs) in Figure 2.5. Except a few cases, the selected suite of ground motions produces accelerations that are greater than the design base accelerations. Therefore, it is expected that the structures exhibit inelastic behavior when subjected to this set of ground motions. 


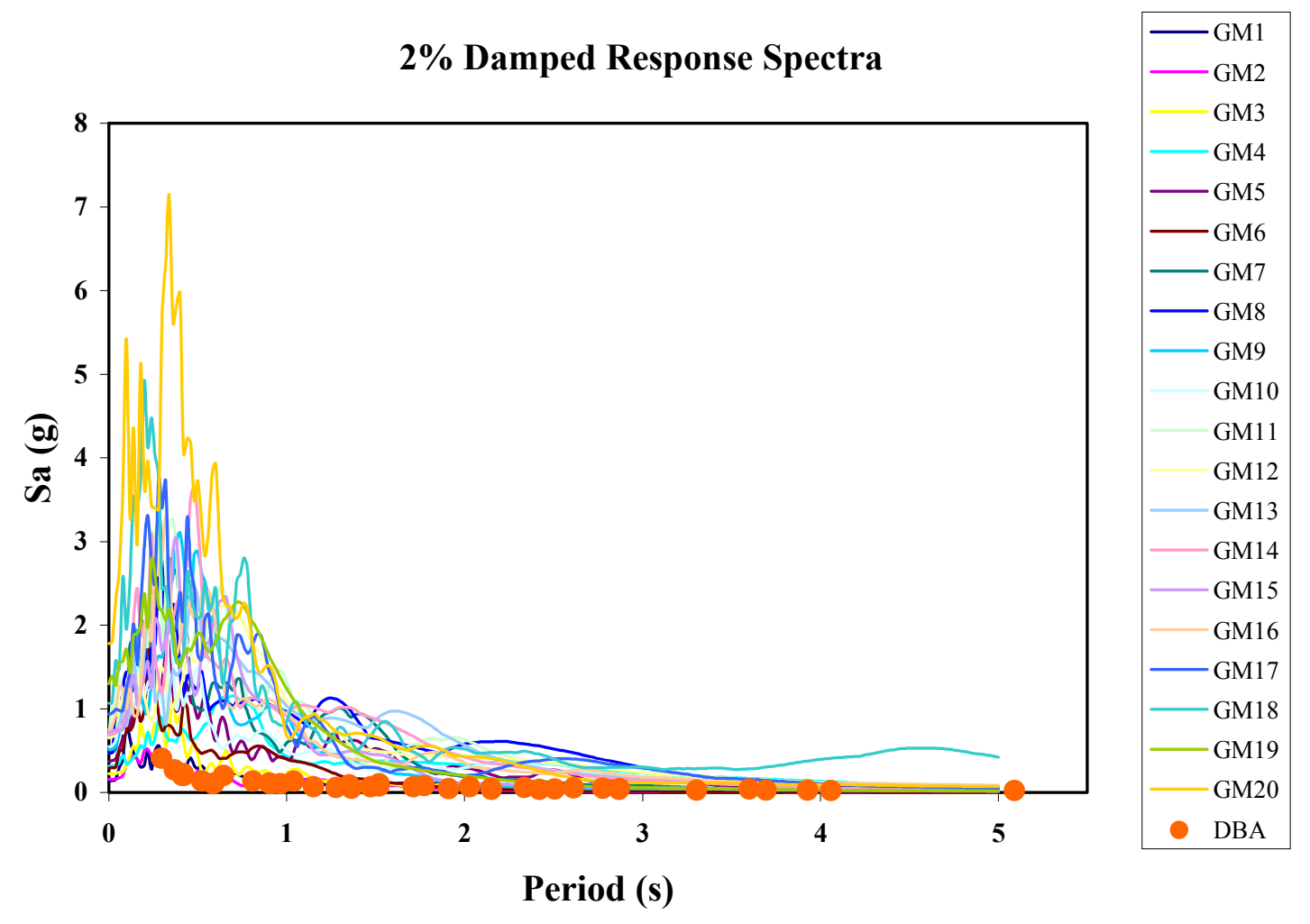

Figure 2.5: Response Spectra for Selected Earthquake Records and Design Base Accelerations for SPSWs.

\subsection{Finite Element Model}

Elastic analyses of the 15 wall-frames were conducted to investigate the variation of the story shears for the wall and the frame. The implicit module of ANSYS (2006) was utilized for this purpose. An inverted triangular lateral load pattern was applied and the story shears resisted by the wall and the frame were recorded at all stories.

The implicit module of ANSYS (2006) was used in order to conduct eigenvalue analysis. 
An explicit finite element code, ANSYS LS-DYNA (2006) was utilized for conducting geometrically nonlinear elastic and inelastic time history analysis. Typical finite element meshes for 9 story wall-frame and wall only systems are given in Figure 2.6 and Figure 2.7, respectively.

As mentioned before, the wall and the frame were modeled separately. This kind of a modeling detail enables to determine the base shears for the wall and the frame precisely. Multi-point constraints were used to equalize the lateral displacements of the wall and the frame at all story levels.

All structures were modeled using shell elements. Beam elements could also be used to model the frame, however, their use was ruled out for the following reasons. Shell elements enable the modeling of the panel zones so that the panel zone deformation effects are automatically included. Preliminary dynamic analyses revealed that the use of beam elements did not significantly reduce the computational time.

Shell163 and Shell93 elements were used for implicit and explicit analysis, respectively. Shell 163 is an eight-node and Shell93 is a four-node shell element with both bending and membrane capabilities. Webs and flanges of beams and columns were modeled with one and two shell elements, respectively. Infill plates were modeled with square shell elements having side lengths of $500 \mathrm{~mm}$. The mesh density was determined after preliminary analysis. Finer meshes were found to produce numerical instabilities.

At each story level lumped masses were placed on eight nodes for dual systems and two nodes for only wall cases. In order to decrease the solution time mass scaling was applied only to shell elements. Preliminary analysis revealed that the effect of the mass scaling is insignificant. Post-buckling response of infill plates were included by introducing a center imperfection of $3 \mathrm{~mm}$. Imperfection values that are within fabrication tolerances do not have a major effect on the capacity (Behbahanifard, 2003). 
Translational and rotational degrees of freedom at the base were restrained. Moreover, out-of-plane movement of the framing was prevented at the beam-column intersections for all stories. The Von Misses yield criterion with bilinear kinematic hardening is used for modeling nonlinear stress-strain behavior of steel. Initial elastic modulus and hardening modulus were taken as 200 and $1 \mathrm{GPa}$ respectively. Shen et al. (1992) reported hardening modulus values between 1.0 and 2.8 GPa for a class of structural steels.

All structures were subjected to the selected suite of earthquake records. Two time history analysis were conducted for each earthquake record where the material nonlinearities were included and excluded.

A $2 \%$ mass proportional damping was used in all analyses. Limited amount of shake table tests revealed that stiff SPSW exhibit 1\% damping (Rezai, 1999)

Time step size for the analysis ranged between 4.47E-5 and 7.0E-5 depending on the smallest element size in the model.

During each analysis, the lateral displacements at every story and the base shear resisted by the wall and the frame were recorded. 


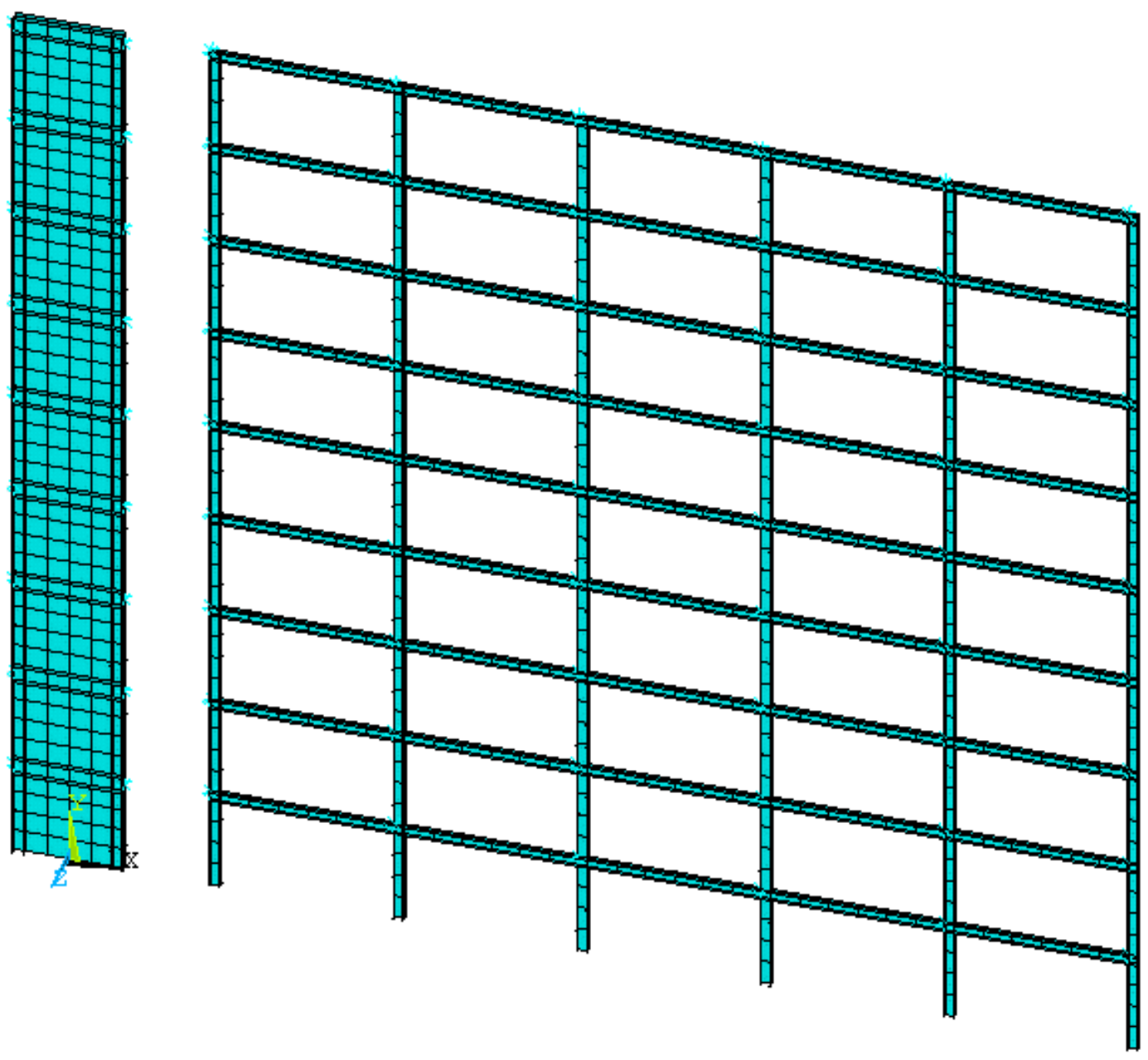

Figure 2.6: A Typical Finite Element Mesh of Wall Frame System 


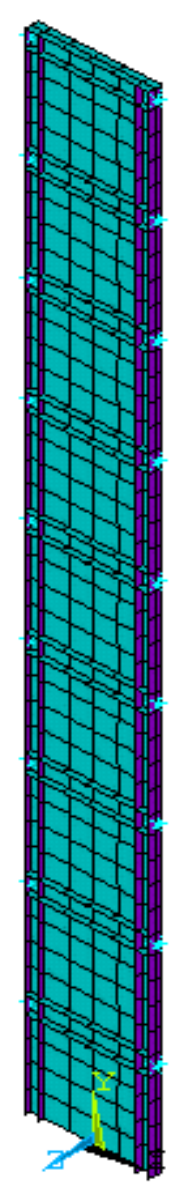

Figure 2.7: A Typical Finite Element Mesh of Wall Only System

\subsection{Model Verification}

The shear force-displacement response of the first story of a four-story SPSW tested by Driver et al. (1998) is shown in Figure 2.8. Examination of this figure reveals that SPSW systems exhibit a complex pinched behavior due to the formation and reorientation of the tension field. In the past, Behbahanifard (2003) showed that the behavior of SPSW systems could be simulated using finite element analysis. 
The quasi-static analysis of the four-story specimen tested by Driver et al. (1998) was conducted using the modeling approach presented herein in the study conducted by Kurban and Topkaya (2009). Comparisons with the experimental results show that the finite element analysis produces acceptable predictions of the base shear capacity. However, the force-displacement response obtained using numerical analysis is less pinched when compared with the experimental one as shown in Figure 2.9.

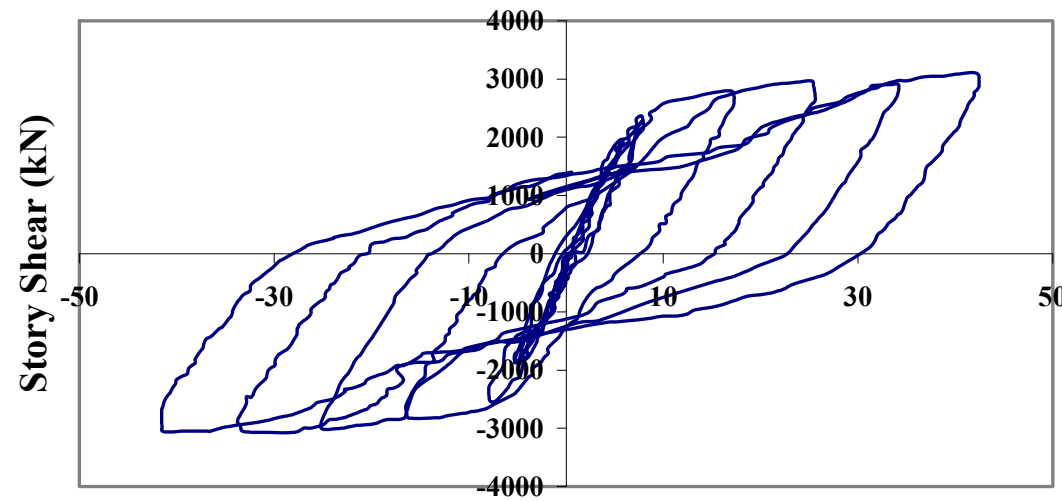

Story Deflection (mm)

Figure 2.8: Shear Force-Displacement Response - Experimental

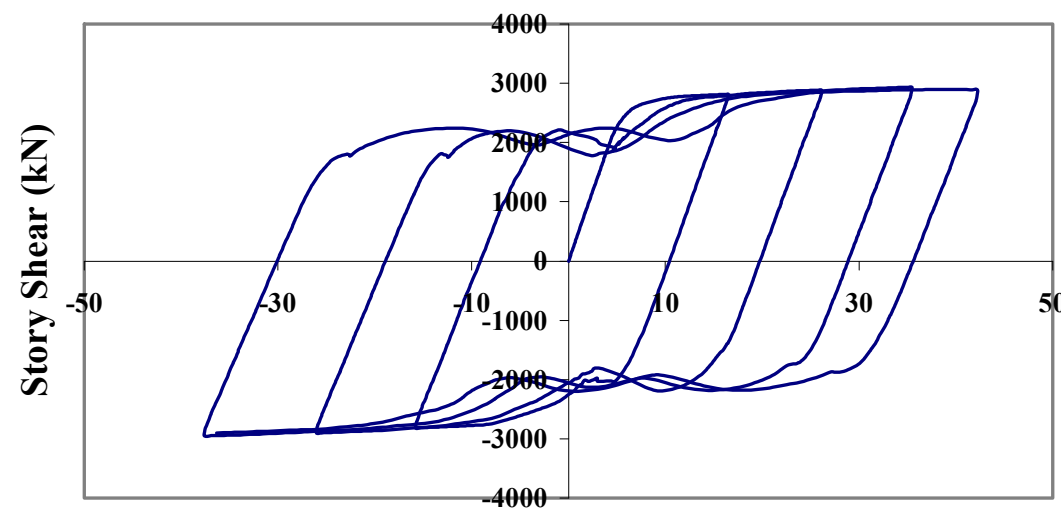

Story Deflection $(\mathrm{mm})$

Figure 2.9: Shear Force-Displacement Response - Numerical 


\title{
CHAPTER 3
}

\begin{abstract}
ANALYSIS RESULTS AND FINDINGS
In general, the response factors are dependent on the amount of ductility that the structure experiences. It is difficult to quantify the ductility level for multi-degree of freedom systems. Two displacement measures were utilized in the present study to quantify the ductility levels. The maximum interstory drift ratio (ISDR) was found by searching through the interstory drifts among all stories. The ISDR is a local measure and can be quite variable among the stories. In addition, a more global measure, maximum top story drift ratio (TSDR) was also utilized. The TSDR can be thought as the average of ISDR values for all stories.
\end{abstract}

\subsection{Elastic Analysis Results}

As previously stated elastic analyses of the 15 wall-frames were conducted to investigate the variation of the story shears for the wall and the frame. The implicit module of ANSYS (2006) was utilized for this purpose. An inverted triangular lateral load pattern was applied and the story shears resisted by the wall and the frame were recorded at all stories. Results are presented separately in Figures 3.1, 3.2, 3.3, 3.4 and 3.5 for wall-frames with different number of stories. It is evident from these figures that the target base shear distribution is satisfied for the selected frame systems. This was further verified through elastic dynamic analysis for which the details are explained later. It is observed that the distribution of story shear is more uniform for low-rise wall-frames. 
On the other hand, as the number of stories increase, the variation in load shares are more pronounced. For top stories, the load shares can significantly differ from the ratio obtained at the base. This is natural in the light of the earlier studies conducted on wall-frames by Heidebrecht and Smith (1973) and Smith and Crowe (1986). Note that for 15 story wall-frames, the ratio can be greater than unity at the topmost story. The wall shear changes sign at this story, resulting in a significant increase in the frame shear.

3 Story Wall-Frames
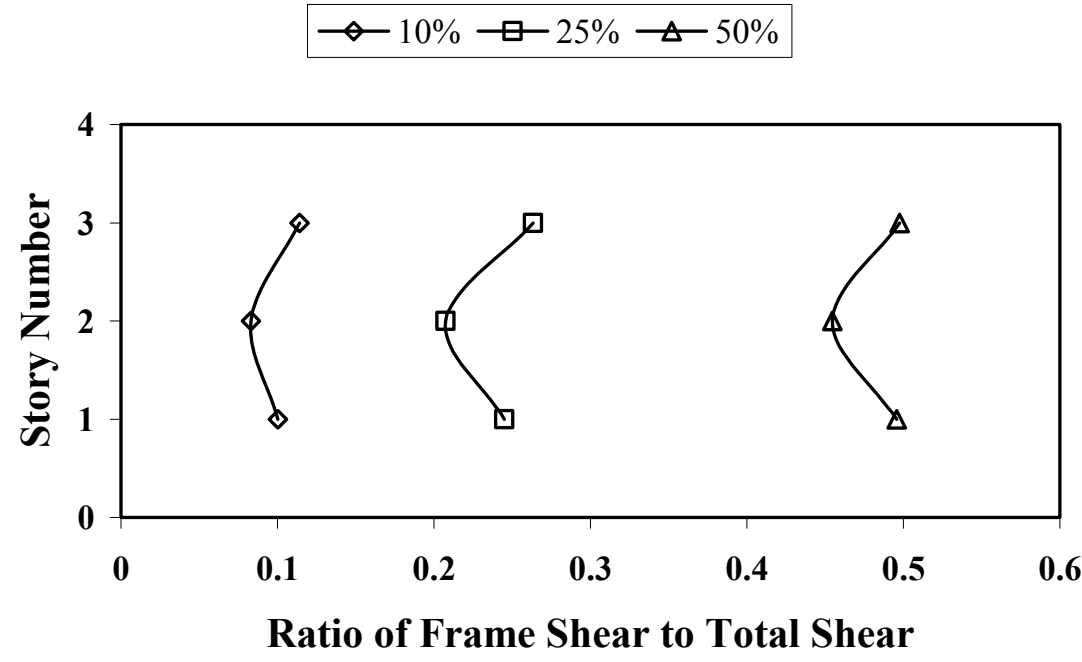

Figure 3.1: Story Shear Ratios Resisted by the Wall and the Frame (3 Story) 


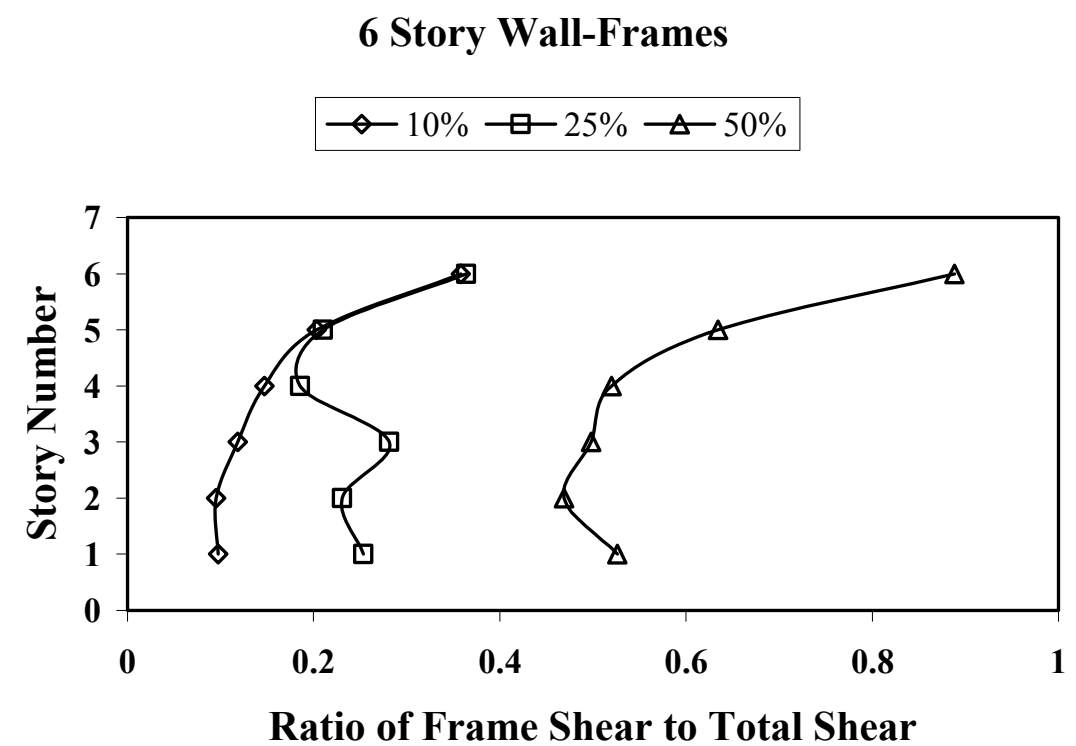

Figure 3.2: Story Shear Ratios Resisted by the Wall and the Frame (6 Story)

\section{Story Wall-Frames}

$\diamond-10 \% \rightarrow-25 \% \rightarrow-50 \%$

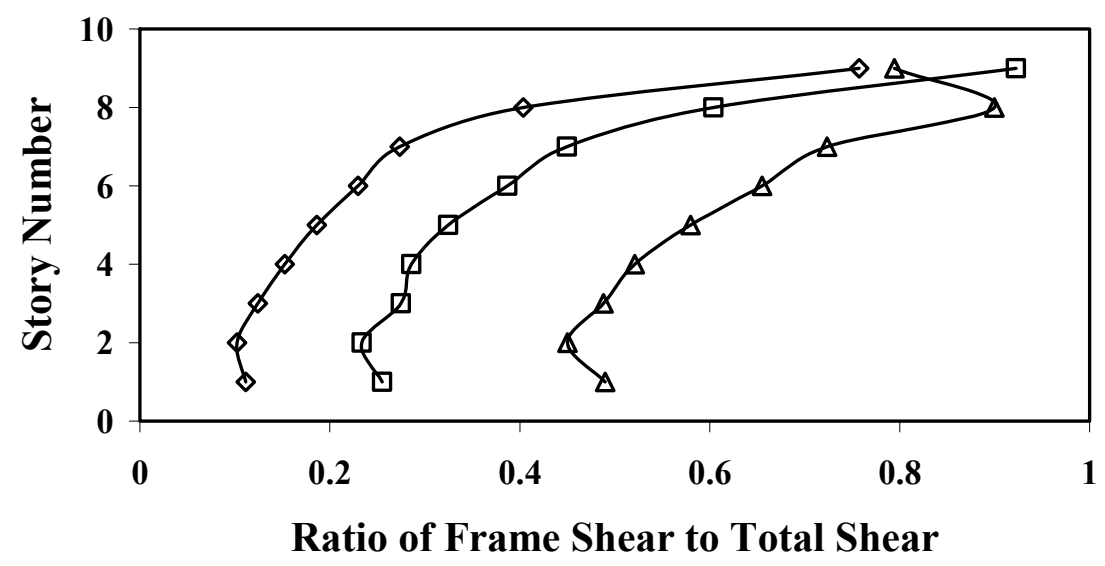

Figure 3.3: Story Shear Ratios Resisted by the Wall and the Frame (9 Story) 


\section{Story Wall-Frames}

$\checkmark-10 \% \square-25 \% \triangle 50 \%$

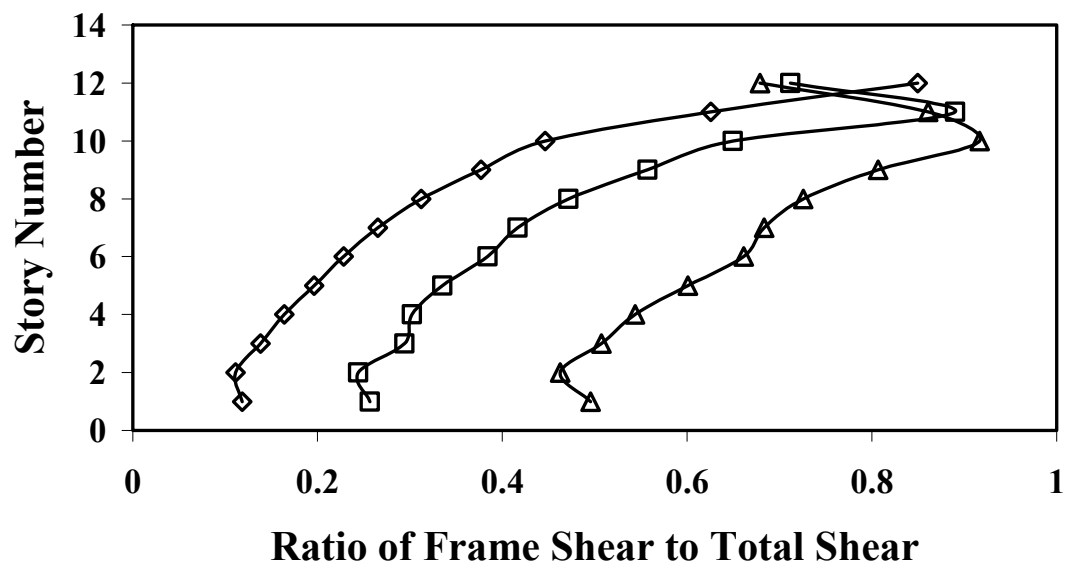

Figure 3.4: Story Shear Ratios Resisted by the Wall and the Frame (12 Story)

15 Story Wall-Frames

$$
\neg-10 \% \rightarrow-25 \% \triangle 50 \%
$$

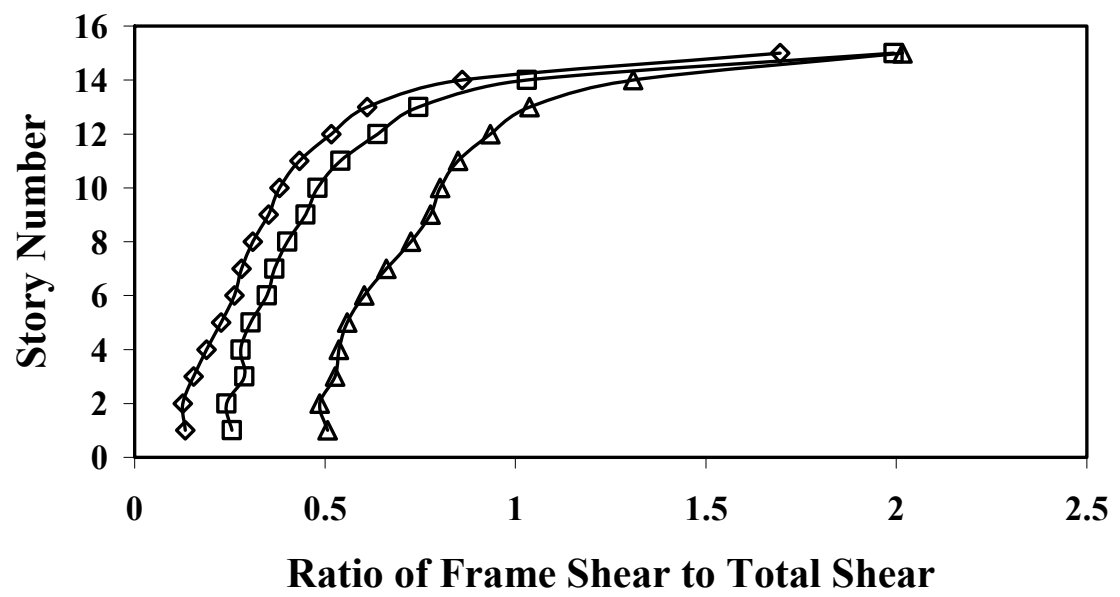

Figure 3.5: Story Shear Ratios Resisted by the Wall and the Frame (15 Story) 


\subsection{Eigenvalue Analysis Results}

The fundamental natural periods of the 40 structures were determined by the finite element procedure using the implicit module of ANSYS (2006). The fundamental natural periods and the modal mass percentages for the systems are given in Tables $3.1,3.2,3.3,3.4,3.5,3.6,3.7$ and 3.8. According to these tables, the fundamental natural periods range between 0.3 and $5.1 \mathrm{sec}$. For low and medium rise structures, the participation of the first mode accounts for $90 \%$ and $75 \%$ of the total mass, respectively.

Table 3.1: Vibration mode properties (100\% - 0\% cases-300 ton)

\begin{tabular}{|c|c|c|c|c|c|c|}
\hline $\begin{array}{l}\text { Story } \\
\text { Number }\end{array}$ & Mode & Frequency & Period & $\begin{array}{c}\text { Mass } \\
\text { Participation }\end{array}$ & $\begin{array}{l}\text { Cumulative } \\
\text { Mass } \\
\text { Participation }\end{array}$ & $\begin{array}{c}\text { Total } \\
2^{\text {nd }} \& 3^{\text {rd }} \text { Mode } \\
\text { Contribution }\end{array}$ \\
\hline \multirow{3}{*}{3} & 1 & 1.71 & 0.586 & $80.4 \%$ & $80.4 \%$ & \\
\hline & 2 & 5.21 & 0.192 & $17.3 \%$ & $97.7 \%$ & \multirow{2}{*}{$17.3 \%$} \\
\hline & 3 & 8.48 & 0.118 & $0.0 \%$ & $97.7 \%$ & \\
\hline \multirow{3}{*}{6} & 1 & 0.73 & 1.365 & $71.8 \%$ & $71.8 \%$ & \\
\hline & 2 & 2.54 & 0.394 & $20.7 \%$ & $92.5 \%$ & \multirow{2}{*}{$26.1 \%$} \\
\hline & 3 & 4.99 & 0.200 & $5.4 \%$ & $97.9 \%$ & \\
\hline \multirow{3}{*}{9} & 1 & 0.41 & 2.420 & $68.8 \%$ & $68.8 \%$ & \\
\hline & 2 & 1.58 & 0.631 & $22.4 \%$ & $91.2 \%$ & \multirow{2}{*}{$28.5 \%$} \\
\hline & 3 & 3.28 & 0.305 & $6.1 \%$ & $97.3 \%$ & \\
\hline \multirow{3}{*}{12} & 1 & 0.25 & 3.929 & $66.9 \%$ & $66.9 \%$ & \\
\hline & 2 & 1.05 & 0.948 & $22.9 \%$ & $89.8 \%$ & \multirow{2}{*}{$30.2 \%$} \\
\hline & 3 & 2.28 & 0.438 & $7.3 \%$ & $97.0 \%$ & \\
\hline \multirow{3}{*}{15} & 1 & 0.20 & 5.092 & $66.6 \%$ & $66.6 \%$ & \\
\hline & 2 & 0.83 & 1.207 & $22.6 \%$ & $89.3 \%$ & \multirow{2}{*}{$30.2 \%$} \\
\hline & 3 & 1.79 & 0.560 & $7.5 \%$ & $96.8 \%$ & \\
\hline
\end{tabular}


Table 3.2: Vibration mode properties ( $90 \%-10 \%$ cases-300 ton)

\begin{tabular}{|c|c|c|c|c|c|c|}
\hline $\begin{array}{c}\text { Story } \\
\text { Number }\end{array}$ & Mode & Frequency & Period & $\begin{array}{c}\text { Mass } \\
\text { Participation }\end{array}$ & $\begin{array}{c}\text { Cumulative } \\
\text { Mass } \\
\text { Participation }\end{array}$ & $\begin{array}{c}\text { Total } \\
2^{\text {nd }} \& 3^{\text {rd }} \text { Mode } \\
\text { Contribution }\end{array}$ \\
\hline \multirow{3}{*}{3} & 1 & 1.69 & 0.593 & $85.1 \%$ & $85.1 \%$ & \\
\hline & 2 & 3.85 & 0.260 & $11.6 \%$ & $96.7 \%$ & \multirow{2}{*}{$14.0 \%$} \\
\hline & 3 & 5.36 & 0.187 & $2.4 \%$ & $99.1 \%$ & \\
\hline \multirow{3}{*}{6} & 1 & 0.78 & 1.277 & $76.3 \%$ & $76.3 \%$ & \\
\hline & 2 & 2.45 & 0.408 & $18.2 \%$ & $94.5 \%$ & \multirow{2}{*}{$22.1 \%$} \\
\hline & 3 & 3.69 & 0.271 & $3.9 \%$ & $98.4 \%$ & \\
\hline \multirow{3}{*}{9} & 1 & 0.47 & 2.151 & $74.1 \%$ & $74.1 \%$ & \\
\hline & 2 & 1.65 & 0.607 & $20.8 \%$ & $94.9 \%$ & \multirow{2}{*}{$25.9 \%$} \\
\hline & 3 & 2.94 & 0.340 & $5.1 \%$ & $100.0 \%$ & \\
\hline \multirow{3}{*}{12} & 1 & 0.30 & 3.305 & $72.1 \%$ & $72.1 \%$ & \\
\hline & 2 & 1.13 & 0.886 & $21.3 \%$ & $93.4 \%$ & \multirow{2}{*}{$27.9 \%$} \\
\hline & 3 & 2.22 & 0.451 & $6.6 \%$ & $100.0 \%$ & \\
\hline \multirow{3}{*}{15} & 1 & 0.25 & 4.059 & $72.2 \%$ & $72.2 \%$ & \\
\hline & 2 & 0.91 & 1.093 & $20.7 \%$ & $92.9 \%$ & \multirow{2}{*}{$27.8 \%$} \\
\hline & 3 & 1.84 & 0.542 & $7.0 \%$ & $100.0 \%$ & \\
\hline
\end{tabular}


Table 3.3: Vibration mode properties ( $75 \%$ - $25 \%$ cases-300 ton)

\begin{tabular}{|c|c|c|c|c|c|c|}
\hline $\begin{array}{l}\text { Story } \\
\text { Number }\end{array}$ & Mode & Frequency & Period & $\begin{array}{c}\text { Mass } \\
\text { Participation }\end{array}$ & $\begin{array}{c}\text { Cumulative } \\
\text { Mass } \\
\text { Participation }\end{array}$ & $\begin{array}{c}\text { Total } \\
2^{\text {nd }} \& 3^{\text {rd }} \text { Mode } \\
\text { Contribution }\end{array}$ \\
\hline \multirow{3}{*}{3} & 1 & 1.91 & 0.523 & $82.5 \%$ & $82.5 \%$ & \\
\hline & 2 & 5.59 & 0.179 & $13.6 \%$ & $96.1 \%$ & \multirow{2}{*}{$16.4 \%$} \\
\hline & 3 & 8.71 & 0.115 & $2.8 \%$ & $98.9 \%$ & \\
\hline \multirow{3}{*}{6} & 1 & 0.87 & 1.151 & $75.6 \%$ & $75.6 \%$ & \\
\hline & 2 & 2.85 & 0.351 & $17.7 \%$ & $93.3 \%$ & \multirow{2}{*}{$22.2 \%$} \\
\hline & 3 & 5.01 & 0.200 & $4.6 \%$ & $97.9 \%$ & \\
\hline \multirow{3}{*}{9} & 1 & 0.52 & 1.911 & $73.0 \%$ & $73.0 \%$ & \\
\hline & 2 & 1.82 & 0.551 & $19.3 \%$ & $92.3 \%$ & \multirow{2}{*}{$24.6 \%$} \\
\hline & 3 & 3.46 & 0.289 & $5.4 \%$ & $97.7 \%$ & \\
\hline \multirow{3}{*}{12} & 1 & 0.35 & 2.868 & $71.6 \%$ & $71.6 \%$ & \\
\hline & 2 & 1.24 & 0.808 & $19.4 \%$ & $91.0 \%$ & \multirow{2}{*}{$25.8 \%$} \\
\hline & 3 & 2.48 & 0.403 & $6.5 \%$ & $97.4 \%$ & \\
\hline \multirow{3}{*}{15} & 1 & 0.27 & 3.695 & $71.0 \%$ & $71.0 \%$ & \\
\hline & 2 & 0.97 & 1.029 & $19.3 \%$ & $90.3 \%$ & \multirow{2}{*}{$26.1 \%$} \\
\hline & 3 & 1.95 & 0.512 & $6.8 \%$ & $97.1 \%$ & \\
\hline
\end{tabular}


Table 3.4: Vibration mode properties (50\% - 50\% cases-300 ton)

\begin{tabular}{|c|c|c|c|c|c|c|}
\hline $\begin{array}{c}\text { Story } \\
\text { Number }\end{array}$ & Mode & Frequency & Period & $\begin{array}{c}\text { Mass } \\
\text { Participation }\end{array}$ & $\begin{array}{c}\text { Cumulative } \\
\text { Mass } \\
\text { Participation }\end{array}$ & $\begin{array}{c}\text { Total } \\
2^{\text {nd }} \& 3^{\text {rd }} \text { Mode } \\
\text { Contribution }\end{array}$ \\
\hline \multirow{3}{*}{3} & 1 & 2.38 & 0.421 & $82.1 \%$ & $82.1 \%$ & \\
\hline & 2 & 7.71 & 0.130 & $14.4 \%$ & $96.5 \%$ & \multirow{2}{*}{$14.5 \%$} \\
\hline & 3 & 13.31 & 0.075 & $0.1 \%$ & $96.6 \%$ & \\
\hline \multirow{3}{*}{6} & 1 & 1.10 & 0.912 & $76.2 \%$ & $76.2 \%$ & \\
\hline & 2 & 3.56 & 0.281 & $16.2 \%$ & $92.4 \%$ & \multirow{2}{*}{$21.3 \%$} \\
\hline & 3 & 6.80 & 0.147 & $5.1 \%$ & $97.5 \%$ & \\
\hline \multirow{3}{*}{9} & 1 & 0.68 & 1.473 & $75.5 \%$ & $75.5 \%$ & \\
\hline & 2 & 2.22 & 0.450 & $16.6 \%$ & $92.1 \%$ & \multirow{2}{*}{$21.9 \%$} \\
\hline & 3 & 4.26 & 0.235 & $5.3 \%$ & $97.4 \%$ & \\
\hline \multirow{3}{*}{12} & 1 & 0.47 & 2.149 & $74.7 \%$ & $74.7 \%$ & \\
\hline & 2 & 1.52 & 0.657 & $16.7 \%$ & $91.4 \%$ & \multirow{2}{*}{$22.6 \%$} \\
\hline & 3 & 2.96 & 0.337 & $5.9 \%$ & $97.3 \%$ & \\
\hline \multirow{3}{*}{15} & 1 & 0.40 & 2.508 & $74.7 \%$ & $74.7 \%$ & \\
\hline & 2 & 1.29 & 0.775 & $15.0 \%$ & $89.7 \%$ & \multirow{2}{*}{$21.0 \%$} \\
\hline & 3 & 2.45 & 0.408 & $6.0 \%$ & $95.7 \%$ & \\
\hline
\end{tabular}


Table 3.5: Vibration mode properties (100\% - 0\% cases- 150 ton)

\begin{tabular}{|c|c|c|c|c|c|c|}
\hline $\begin{array}{l}\text { Story } \\
\text { Number }\end{array}$ & Mode & Frequency & Period & $\begin{array}{c}\text { Mass } \\
\text { Participation }\end{array}$ & $\begin{array}{c}\text { Cumulative } \\
\text { Mass } \\
\text { Participation }\end{array}$ & $\begin{array}{c}\text { Total } \\
2^{\text {nd }} \& 3^{\text {rd }} \text { Mode } \\
\text { Contribution }\end{array}$ \\
\hline \multirow{3}{*}{3} & 1 & 2.41 & 0.414 & $80.4 \%$ & $80.4 \%$ & \\
\hline & 2 & 7.37 & 0.136 & $17.3 \%$ & $97.7 \%$ & \multirow{2}{*}{$17.3 \%$} \\
\hline & 3 & 12.00 & 0.083 & $0.0 \%$ & $97.7 \%$ & \\
\hline \multirow{3}{*}{6} & 1 & 1.04 & 0.966 & $71.8 \%$ & $71.8 \%$ & \\
\hline & 2 & 3.59 & 0.279 & $20.7 \%$ & $92.5 \%$ & \multirow{2}{*}{$26.1 \%$} \\
\hline & 3 & 7.05 & 0.142 & $5.4 \%$ & $97.9 \%$ & \\
\hline \multirow{3}{*}{9} & 1 & 0.58 & 1.711 & $68.8 \%$ & $68.8 \%$ & \\
\hline & 2 & 2.24 & 0.446 & $22.4 \%$ & $91.2 \%$ & \multirow{2}{*}{$28.5 \%$} \\
\hline & 3 & 4.64 & 0.216 & $6.1 \%$ & $97.3 \%$ & \\
\hline \multirow{3}{*}{12} & 1 & 0.36 & 2.778 & $66.9 \%$ & $66.9 \%$ & \\
\hline & 2 & 1.49 & 0.671 & $22.9 \%$ & $89.8 \%$ & \multirow{2}{*}{$30.2 \%$} \\
\hline & 3 & 3.23 & 0.310 & $7.3 \%$ & $97.0 \%$ & \\
\hline \multirow{3}{*}{15} & 1 & 0.28 & 3.600 & $66.2 \%$ & $66.2 \%$ & \\
\hline & 2 & 1.17 & 0.853 & $23.0 \%$ & $89.3 \%$ & \multirow{2}{*}{$30.6 \%$} \\
\hline & 3 & 2.53 & 0.396 & $7.5 \%$ & $96.8 \%$ & \\
\hline
\end{tabular}


Table 3.6: Vibration mode properties ( $90 \%$ - 10\% cases- 150 ton)

\begin{tabular}{|c|c|c|c|c|c|c|}
\hline $\begin{array}{c}\text { Story } \\
\text { Number }\end{array}$ & Mode & Frequency & Period & $\begin{array}{c}\text { Mass } \\
\text { Participation }\end{array}$ & $\begin{array}{c}\text { Cumulative } \\
\text { Mass } \\
\text { Participation }\end{array}$ & $\begin{array}{c}\text { Total } \\
2^{\text {nd }} \& 3^{\text {rd }} \text { Mode } \\
\text { Contribution }\end{array}$ \\
\hline \multirow{3}{*}{3} & 1 & 2.38 & 0.420 & $85.1 \%$ & $85.1 \%$ & \\
\hline & 2 & 5.44 & 0.184 & $11.6 \%$ & $96.7 \%$ & \multirow{2}{*}{$14.0 \%$} \\
\hline & 3 & 7.58 & 0.132 & $2.4 \%$ & $99.1 \%$ & \\
\hline \multirow{3}{*}{6} & 1 & 1.11 & 0.903 & $76.3 \%$ & $76.3 \%$ & \\
\hline & 2 & 3.46 & 0.289 & $18.2 \%$ & $94.5 \%$ & \multirow{2}{*}{$22.1 \%$} \\
\hline & 3 & 5.22 & 0.191 & $3.9 \%$ & $98.4 \%$ & \\
\hline \multirow{3}{*}{9} & 1 & 0.66 & 1.521 & $74.1 \%$ & $74.1 \%$ & \\
\hline & 2 & 2.33 & 0.429 & $20.8 \%$ & $94.9 \%$ & \multirow{2}{*}{$25.9 \%$} \\
\hline & 3 & 4.16 & 0.240 & $5.1 \%$ & $100.0 \%$ & \\
\hline \multirow{3}{*}{12} & 1 & 0.43 & 2.337 & $72.1 \%$ & $72.1 \%$ & \\
\hline & 2 & 1.60 & 0.626 & $21.3 \%$ & $93.4 \%$ & \multirow{2}{*}{$27.9 \%$} \\
\hline & 3 & 3.13 & 0.319 & $6.6 \%$ & $100.0 \%$ & \\
\hline \multirow{3}{*}{15} & 1 & 0.35 & 2.870 & $72.2 \%$ & $72.2 \%$ & \\
\hline & 2 & 1.29 & 0.773 & $20.7 \%$ & $92.9 \%$ & \multirow{2}{*}{$27.8 \%$} \\
\hline & 3 & 2.61 & 0.383 & $7.0 \%$ & $100.0 \%$ & \\
\hline
\end{tabular}


Table 3.7: Vibration mode properties $(75 \%-25 \%$ cases- 150 ton)

\begin{tabular}{|c|c|c|c|c|c|c|}
\hline $\begin{array}{c}\text { Story } \\
\text { Number }\end{array}$ & Mode & Frequency & Period & $\begin{array}{c}\text { Mass } \\
\text { Participation }\end{array}$ & $\begin{array}{c}\text { Cumulative } \\
\text { Mass } \\
\text { Participation }\end{array}$ & $\begin{array}{c}\text { Total } \\
2^{\text {nd }} \& 3^{\text {rd }} \text { Mode } \\
\text { Contribution }\end{array}$ \\
\hline \multirow{3}{*}{3} & 1 & 2.70 & 0.370 & $82.5 \%$ & $82.5 \%$ & \\
\hline & 2 & 7.91 & 0.126 & $13.6 \%$ & $96.1 \%$ & \multirow{2}{*}{$16.4 \%$} \\
\hline & 3 & 12.32 & 0.081 & $2.8 \%$ & $98.9 \%$ & \\
\hline \multirow{3}{*}{6} & 1 & 1.23 & 0.814 & $75.6 \%$ & $75.6 \%$ & \\
\hline & 2 & 4.02 & 0.249 & $17.7 \%$ & $93.3 \%$ & \multirow{2}{*}{$22.2 \%$} \\
\hline & 3 & 7.09 & 0.141 & $4.6 \%$ & $97.9 \%$ & \\
\hline \multirow{3}{*}{9} & 1 & 0.74 & 1.351 & $73.0 \%$ & $73.0 \%$ & \\
\hline & 2 & 2.57 & 0.390 & $19.3 \%$ & $92.3 \%$ & \multirow{2}{*}{$24.6 \%$} \\
\hline & 3 & 4.90 & 0.204 & $5.4 \%$ & $97.7 \%$ & \\
\hline \multirow{3}{*}{12} & 1 & 0.49 & 2.028 & $71.6 \%$ & $71.6 \%$ & \\
\hline & 2 & 1.75 & 0.571 & $19.4 \%$ & $91.0 \%$ & \multirow{2}{*}{$25.8 \%$} \\
\hline & 3 & 3.51 & 0.285 & $6.5 \%$ & $97.4 \%$ & \\
\hline \multirow{3}{*}{15} & 1 & 0.38 & 2.613 & $71.0 \%$ & $71.0 \%$ & \\
\hline & 2 & 1.37 & 0.728 & $19.3 \%$ & $90.3 \%$ & \multirow{2}{*}{$26.1 \%$} \\
\hline & 3 & 2.76 & 0.362 & $6.8 \%$ & $97.1 \%$ & \\
\hline
\end{tabular}


Table 3.8: Vibration mode properties (50\% - 50\% cases- 150 ton)

\begin{tabular}{|c|c|c|c|c|c|c|}
\hline $\begin{array}{c}\text { Story } \\
\text { Number }\end{array}$ & Mode & Frequency & Period & $\begin{array}{c}\text { Mass } \\
\text { Participation }\end{array}$ & $\begin{array}{c}\text { Cumulative } \\
\text { Mass } \\
\text { Participation }\end{array}$ & $\begin{array}{c}\text { Total } \\
2^{\text {nd }} \& 3^{\text {rd }} \text { Mode } \\
\text { Contribution }\end{array}$ \\
\hline \multirow{3}{*}{3} & 1 & 3.36 & 0.298 & $82.1 \%$ & $82.1 \%$ & \\
\hline & 2 & 10.91 & 0.092 & $14.5 \%$ & $96.5 \%$ & \multirow{2}{*}{$14.5 \%$} \\
\hline & 3 & 18.82 & 0.053 & $0.1 \%$ & $96.6 \%$ & \\
\hline \multirow{3}{*}{6} & 1 & 1.55 & 0.645 & $76.2 \%$ & $76.2 \%$ & \\
\hline & 2 & 5.04 & 0.198 & $16.2 \%$ & $92.4 \%$ & \multirow{2}{*}{$21.2 \%$} \\
\hline & 3 & 9.61 & 0.104 & $5.0 \%$ & $97.4 \%$ & \\
\hline \multirow{3}{*}{9} & 1 & 0.96 & 1.040 & $75.5 \%$ & $75.5 \%$ & \\
\hline & 2 & 3.14 & 0.318 & $16.6 \%$ & $92.1 \%$ & \multirow{2}{*}{$22.0 \%$} \\
\hline & 3 & 6.02 & 0.166 & $5.4 \%$ & $97.5 \%$ & \\
\hline \multirow{3}{*}{12} & 1 & 0.66 & 1.520 & $74.7 \%$ & $74.7 \%$ & \\
\hline & 2 & 2.15 & 0.465 & $16.7 \%$ & $91.4 \%$ & \multirow{2}{*}{$22.6 \%$} \\
\hline & 3 & 4.19 & 0.239 & $5.9 \%$ & $97.3 \%$ & \\
\hline \multirow{3}{*}{15} & 1 & 0.56 & 1.773 & $74.7 \%$ & $74.7 \%$ & \\
\hline & 2 & 1.83 & 0.548 & $15.0 \%$ & $89.7 \%$ & \multirow{2}{*}{$21.0 \%$} \\
\hline & 3 & 3.47 & 0.288 & $6.0 \%$ & $95.7 \%$ & \\
\hline
\end{tabular}




\subsection{Time History Analysis Results}

As mentioned before two displacement measures (maximum interstory drift ratio (ISDR) and maximum top story drift ratio (TSDR)) were utilized in the present study to quantify the ductility levels. In order to determine some of the response quantities, pushover-like curves were developed for each structure. Representative pushoverlike curves for 9 story systems with $25 \%$ and $0 \%$ frame share are given in Figure 3.6. Basically, the maximum amount of base shear resisted by the system is plotted against a displacement measure (ISDR or TSDR) for the 20 ground motions. A straight line was fitted to the elastic analysis results to represent the elastic response. An elastic perfectly plastic curve was fitted to the data (Uang, 1991) to find the base shear at the structural collapse level $\left(V_{y}\right)$. These two curves were utilized to determine the displacements at the first significant yield $\left(\Delta_{\mathrm{s}}\right)$ and the structural collapse level $\left(\Delta_{\mathrm{y}}\right)$. The $\Delta_{\mathrm{s}}$ and $\Delta_{\mathrm{y}}$ values for the ISDR and TSDR are given in Tables 3.9, 3.10, 3.11 and 3.12 in terms of percentages. If the interstory drifts presented in these tables are amplified by a $C_{d}$ factor between 6 and 7 as recommended by the IBC specification (2003), it can be observed that the structures conform to the typical drift limitations (between 2 and 3 percent) set forth by the design specifications (ASCE, 2005). Therefore, the selected structures provide the necessary lateral stiffness, and are not too flexible.

Pushover-like curves were also developed for the wall and the frame as shown in Figure 3.7. These were used to determine the base shear resisted by the wall and the frame at the structural collapse level. In addition, the ratio of base shear resisted by the frame to the total base shear was investigated for the elastic response and the original base shear ratios derived through quasi-static analysis were verified through dynamic analysis. 
9 Story Systems

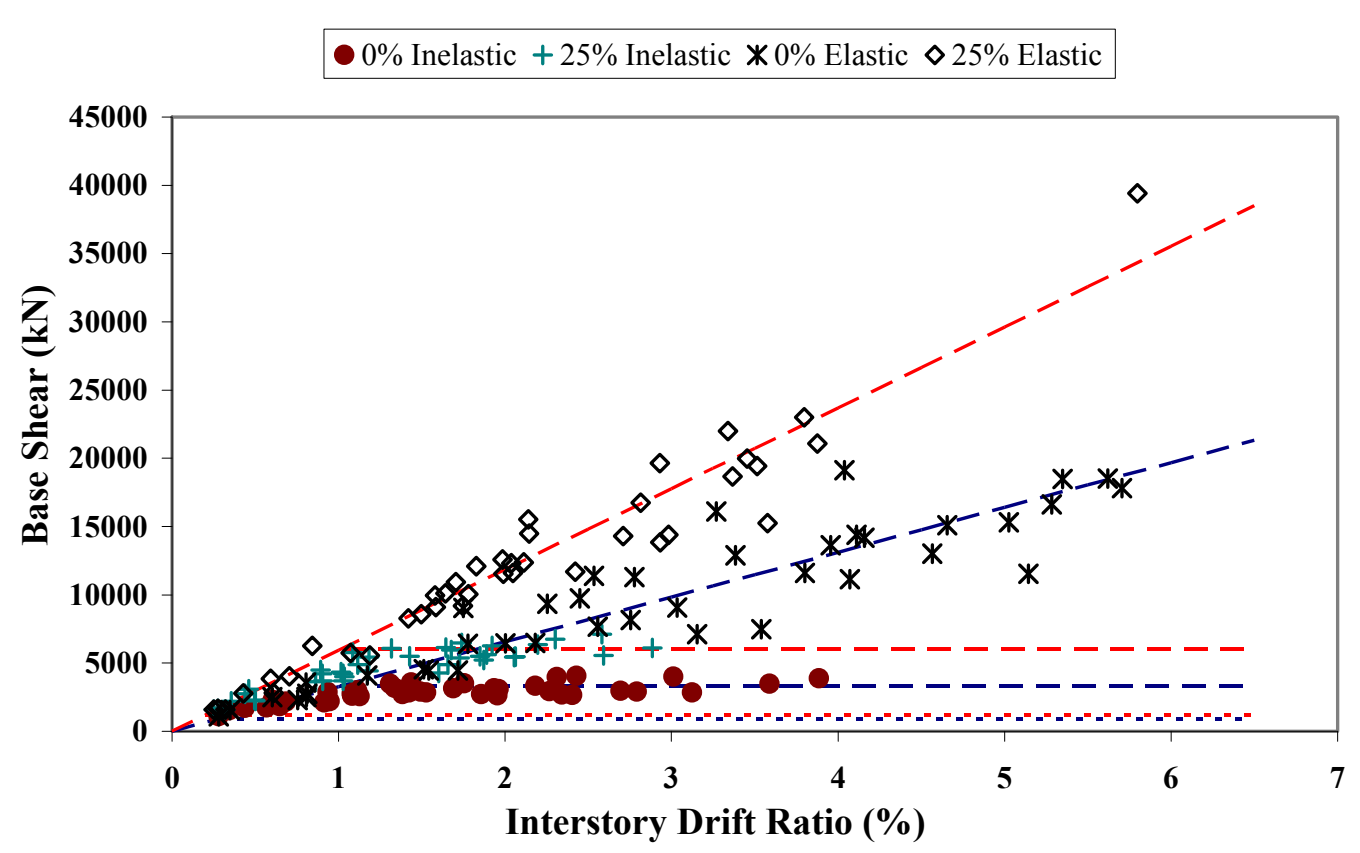

Figure 3.6: Pushover-Like Curves for 9 Story Systems - 25\% and 0\% Frame Share

9 story system 50\% Frame Contribution

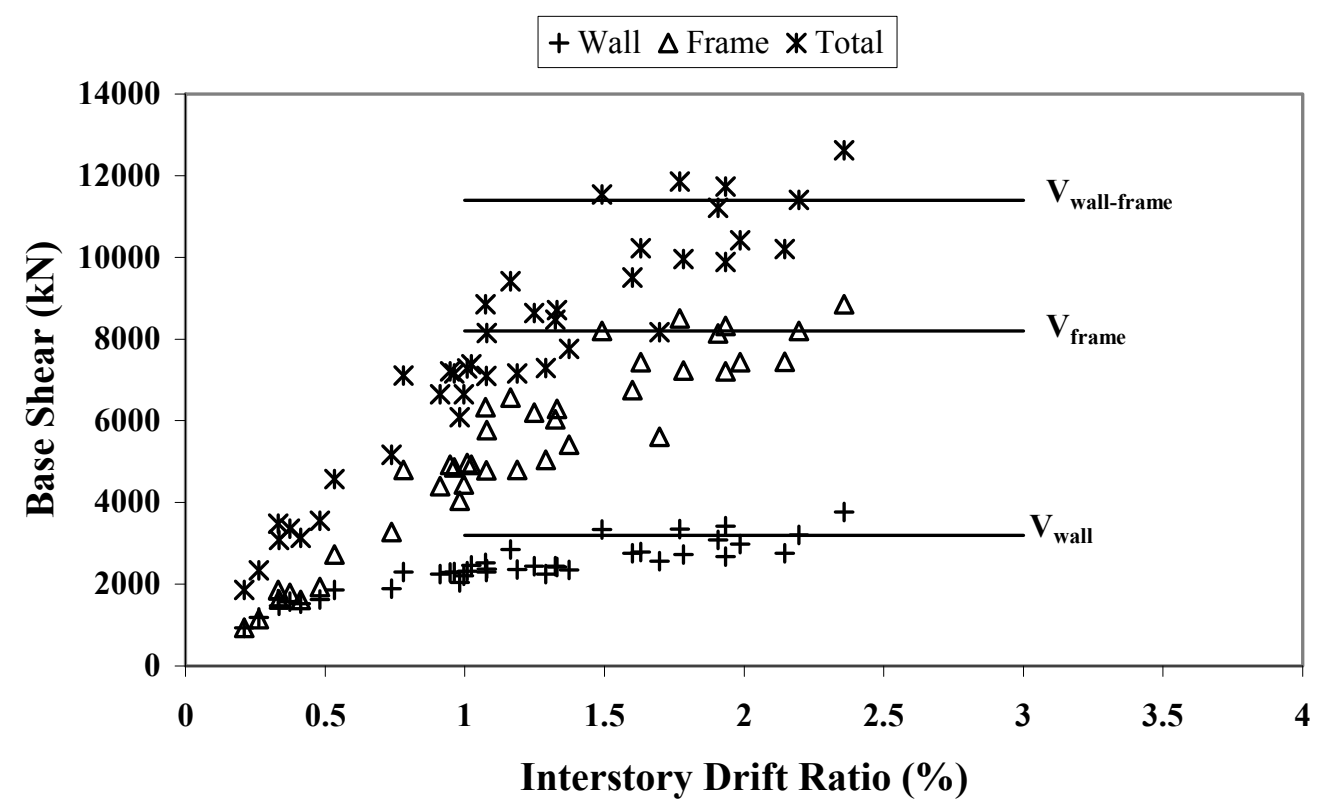

Figure 3.7: Pushover-Like Curves for the Wall-Frame, Wall and Frame 
Table 3.9: $\operatorname{ISDR}_{\mathrm{s}}, \mathrm{ISDR}_{\mathrm{y}}, \mathrm{TSDR}_{\mathrm{s}}$, and $\mathrm{TSDR}_{\mathrm{y}}(100 \%$ - $0 \%$ cases $)$

\begin{tabular}{|c|c|c|c|c|}
\hline Story \# & $(\text { ISDR })_{\mathrm{s}}$ & $(\text { ISDR })_{\mathrm{y}}$ & $(\mathrm{TSDR})_{\mathrm{s}}$ & $(\mathrm{TSDR})_{\mathrm{y}}$ \\
\hline 3 & 0.15 & 0.46 & 0.13 & 0.39 \\
\hline 6 & 0.22 & 0.77 & 0.15 & 0.53 \\
\hline 9 & 0.28 & 1.01 & 0.15 & 0.56 \\
\hline 12 & 0.29 & 1.04 & 0.13 & 0.48 \\
\hline 15 & 0.29 & 1.12 & 0.12 & 0.45 \\
\hline
\end{tabular}

Table 3.10: ISDR $, \mathrm{ISDR}_{\mathrm{y}}, \mathrm{TSDR}_{\mathrm{s}}$, and $\mathrm{TSDR}_{\mathrm{y}}(90 \%$ - $10 \%$ cases $)$

\begin{tabular}{|c|c|c|c|c|}
\hline Story \# & $(\text { ISDR })_{\mathrm{s}}$ & $(\text { ISDR })_{\mathrm{y}}$ & $(\mathrm{TSDR})_{\mathrm{s}}$ & $(\mathrm{TSDR})_{\mathrm{y}}$ \\
\hline 3 & 0.14 & 0.49 & 0.13 & 0.44 \\
\hline 6 & 0.20 & 0.72 & 0.15 & 0.55 \\
\hline 9 & 0.23 & 0.97 & 0.15 & 0.60 \\
\hline 12 & 0.27 & 1.07 & 0.15 & 0.57 \\
\hline 15 & 0.23 & 0.99 & 0.11 & 0.46 \\
\hline
\end{tabular}

Table 3.11: $\mathrm{ISDR}_{\mathrm{s}}, \mathrm{ISDR}_{\mathrm{y}}, \mathrm{TSDR}_{\mathrm{s}}$, and $\mathrm{TSDR}_{\mathrm{y}}(75 \%$ - 25\% cases $)$

\begin{tabular}{|c|c|c|c|c|}
\hline Story \# & $(\text { ISDR })_{\mathrm{s}}$ & $(\text { ISDR })_{\mathrm{y}}$ & $(\mathrm{TSDR})_{\mathrm{s}}$ & $(\mathrm{TSDR})_{\mathrm{y}}$ \\
\hline 3 & 0.14 & 0.68 & 0.13 & 0.60 \\
\hline 6 & 0.18 & 0.83 & 0.13 & 0.62 \\
\hline 9 & 0.20 & 1.02 & 0.13 & 0.64 \\
\hline 12 & 0.26 & 1.14 & 0.14 & 0.62 \\
\hline 15 & 0.25 & 1.12 & 0.13 & 0.59 \\
\hline
\end{tabular}


Table 3.12: $\operatorname{ISDR}_{\mathrm{s}}, \mathrm{ISDR}_{\mathrm{y}}, \mathrm{TSDR}_{\mathrm{s}}$, and $\mathrm{TSDR}_{\mathrm{y}}(50 \%-50 \%$ cases $)$

\begin{tabular}{|c|c|c|c|c|}
\hline Story \# & $(\text { ISDR })_{\mathrm{s}}$ & $(\text { ISDR })_{\mathrm{y}}$ & $(\mathrm{TSDR})_{\mathrm{s}}$ & $(\mathrm{TSDR})_{\mathrm{y}}$ \\
\hline 3 & 0.14 & 1.01 & 0.12 & 0.86 \\
\hline 6 & 0.18 & 1.10 & 0.13 & 0.83 \\
\hline 9 & 0.19 & 1.18 & 0.12 & 0.79 \\
\hline 12 & 0.23 & 1.36 & 0.14 & 0.81 \\
\hline 15 & 0.19 & 1.11 & 0.11 & 0.64 \\
\hline
\end{tabular}

After each inelastic analysis, the yielding patterns of the wall-frames were investigated. In general, systems experienced uniform yielding with no sign of soft story mechanism. In Figure 3.8 Von Mises plastic strain plot is given for a six story wall frame system with $10 \%$ frame contribution.

The following sections present detailed investigations for each response factor and their relation to the elastic load share between the wall and the frame. 


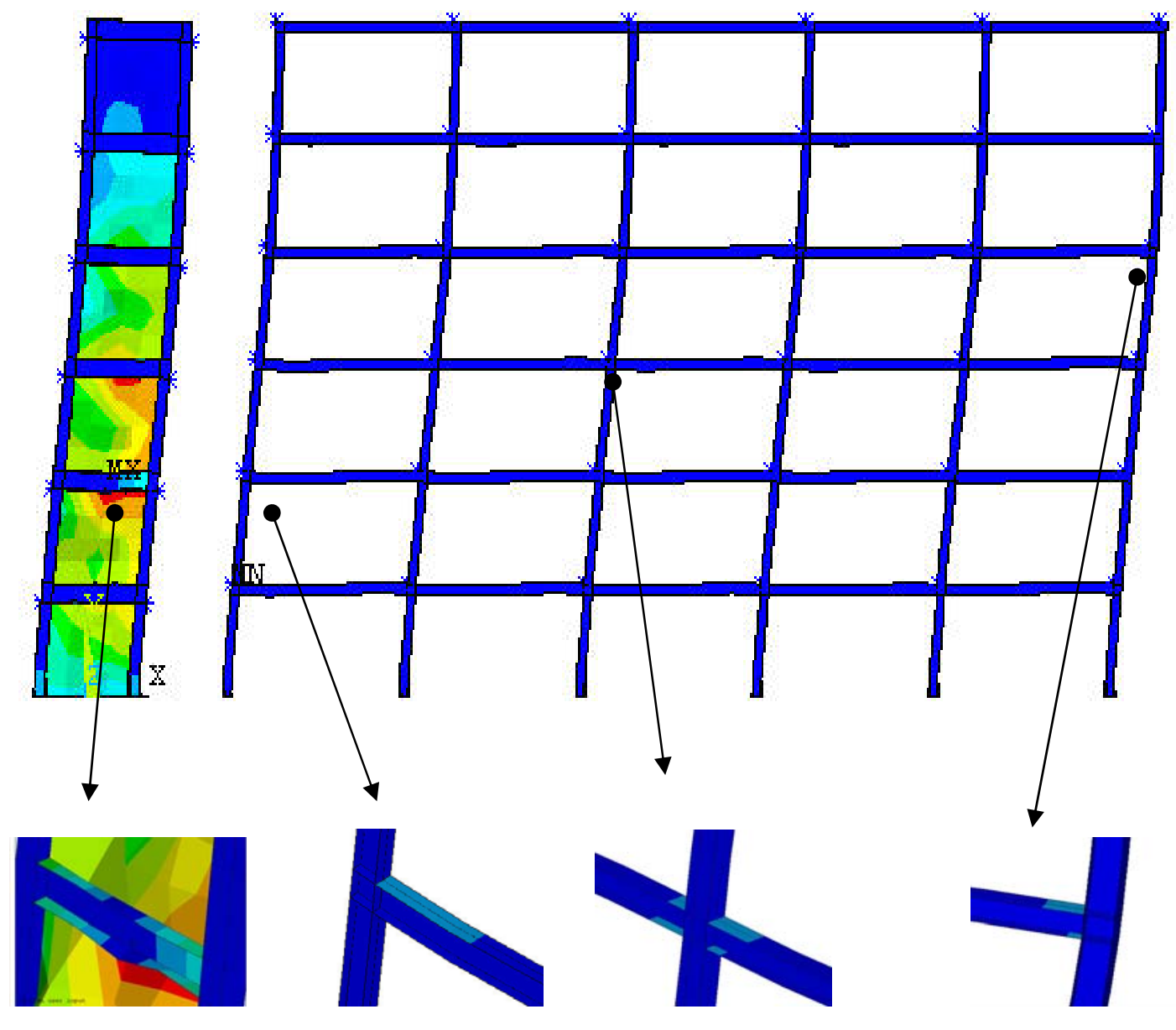

Figure 3.8: A plot of Von Mises Plastic Strain 


\subsection{Overstrength Factor and Estimation of Base Shear at the Collapse Level}

The primary source of overstrength in the present study is the redundancy possessed by the systems. The overstrength of a particular structure can be estimated either by nonlinear static analysis methods or by nonlinear time history analysis. Each analysis method has its advantages and disadvantages. The nonlinear static analysis procedures such as the pushover analysis or simple plastic analysis require to use a predetermined lateral load profile and consider only the first mode response. On the other hand, pushover-like curves based on nonlinear time history analysis take into account the higher mode effects but the results are dependent on the ground motion characteristics.

It should be recognized that the redundancy of these systems are due to the boundary framing and the framing outside the wall. As shown by Sabouri-Ghomi and Roberts (1991 and 1992) and Roberts (1995) the lateral loads acting on the wall are carried by the frame action of VBE and HBE after the infill plate yields. In addition, the frame members other than the boundary framing provide a resistance against lateral loads. Therefore, the overstrength of the dual system is significantly affected by the frame members and the boundary framing (i.e. HBE and VBE).

In the present study, the pushover-like curves obtained from the results of nonlinear time history analysis were utilized to develop a simple hand method for estimating the base shear at the collapse level. Furthermore, the same results were used to determine the overstrength of the systems studied herein.

As shown in Figure 3.7, the base shears at the collapse level for the wall, the frame, and the wall-frame can be found from pushover-like curves. A simple hand method is developed herein to predict these base shear values. The estimates from simple 
plastic analysis were correlated with the results of nonlinear time history analysis for this purpose. The simple plastic analysis for SPSWs proposed by Berman and Bruneau (2003) can be extended to dual systems. For a wall with constant infill plate thickness, the base shear at the collapse level $\left(V_{w}\right)$ can be calculated as follows (Berman and Bruneau, 2003):

$$
V_{w}=\frac{1}{c_{w} h_{T}}\left(0.5 F_{y} L_{c f} t_{w} h_{T}+\sum_{i=1}^{n_{s}} 2 M_{p i(H B E)}+2 M_{p(V B E)}\right)
$$

Where,

$$
\begin{array}{ll}
h_{t} & : \text { Total height } \\
M_{p(V B E)} & : \text { The plastic moment capacity of VBE at the base } \\
M_{p i(H B E)} & : \text { The plastic moment capacity of HBE at the } \mathrm{i}^{\text {th }} \text { story } \\
n_{s} & : \text { The number of story } \\
c_{w} & : \text { A coefficient depending on the distribution of lateral loads }
\end{array}
$$

Similarly, the base shear at collapse level for the frame $\left(V_{f}\right)$ can be calculated as follows:

$$
V_{f}=\frac{1}{c_{f} h_{T}}\left(\sum_{i=1}^{n_{s}} n_{b} 2 M_{p b i}+\left(n_{b}+1\right) M_{p c}\right)
$$

Where,

$$
\begin{aligned}
& n_{b} \quad: \text { The number of bays } \\
& M_{p b i} \quad: \text { The plastic moment capacity of beam at the } \mathrm{i}^{\text {th }} \text { story } \\
& M_{p c} \quad: \text { The plastic moment capacity of columns at the base level }
\end{aligned}
$$


$c_{f} \quad$ : A coefficient depending on the distribution of lateral loads

The base shear at collapse level for the wall-frame $\left(V_{w f}\right)$ can be calculated by combining the previous expressions as follows:

$$
V_{w f}=\frac{1}{c_{w f} h_{T}}\left(0.5 F_{y} L_{c f} t_{w} h_{T}+\sum_{i=1}^{n_{s}} 2 M_{p i(H B E)}+2 M_{p(V B E)}+\sum_{i=1}^{n_{s}} n_{b} 2 M_{p b i}+\left(n_{b}+1\right) M_{p c}\right)
$$

Where,

$$
c_{w f}: \text { A coefficient depending on the distribution of lateral loads }
$$

Lateral load distribution factors $c_{w}, c_{f}$, and $c_{w f}$, have to be assumed in using the simple plastic analysis to estimate the base shear at the collapse level.

The distribution factor is equal to 0.5 for equal lateral loads at all stories and is equal to 0.67 for inverted triangular distribution. Time history analysis results were utilized in order to obtain the lateral load distribution factors. The distribution factors are given in Figures 3.9, 3.10, and 3.11 for the walls, the frames and the wallframes, respectively. The average value of the distribution factor for each case is also plotted in these figures. For the wall-frames, the average $c_{w f}$ value is 0.66 indicating a load distribution similar to the inverted triangular distribution. The resultant load distribution on the wall and the frame may be different due to the wallframe interaction. As shown in Figures 3.1, 3.2, 3.3, 3.4 and 3.5 the distribution of story shears for the frame can change significantly over the height if the number of stories increases. The average $c_{w}$ and $c_{f}$ values are 0.54 and 0.77 , respectively. In addition, these values vary with the ratio of the frame base shear to the total elastic base shear $(\xi)$. The $c_{w}$ factor increases while the $c_{f}$ factor decreases with $\xi$. Also it is observed that the values for 3 story structures are different than the ones of taller 
structures. The values presented in Figures 3.9, 3.10, and 3.11 can be used in simple plastic analysis to estimate the base shear at the collapse level.

The ratio of frame base shear to the total base shear can significantly change when the system experiences yielding. In Figure 3.12 the contribution of the frame resistance to the total inelastic base shear resistance is plotted against the same ratio for the elastic response. According to this figure, the frame contribution is even more significant for the inelastic response. For example, this ratio reaches to $80 \%$ for cases with $50 \%$ elastic load share.

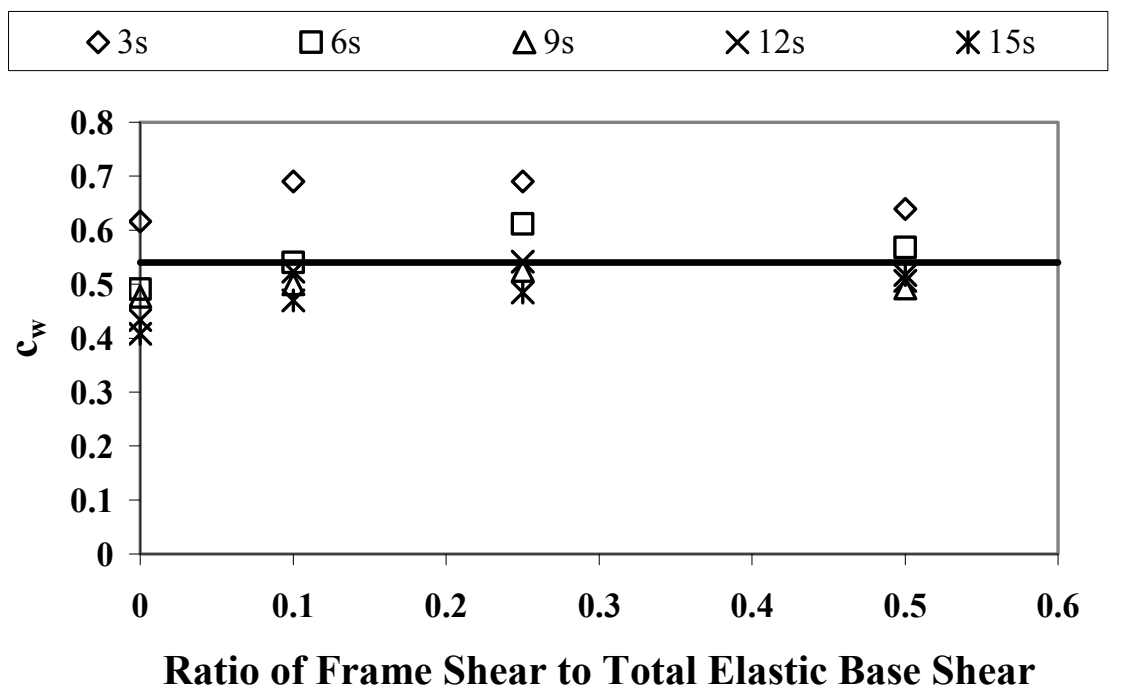

Figure 3.9: The Distribution Factors for the Wall 


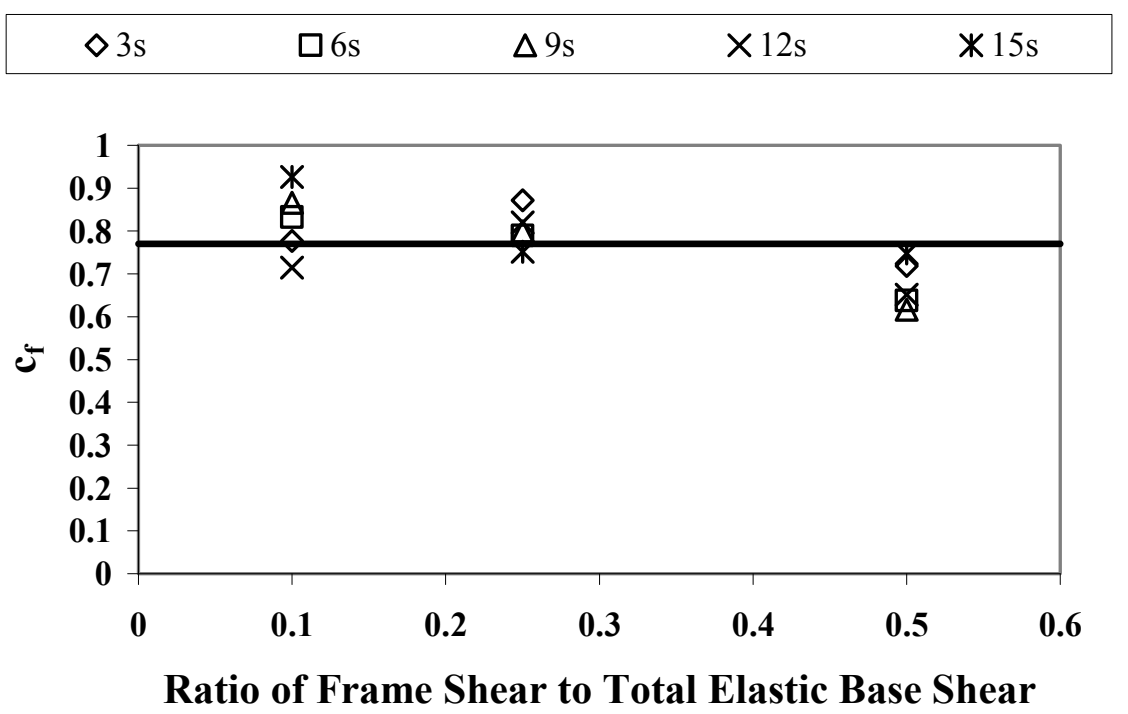

Figure 3.10: The Distribution Factors for the Frame

\begin{tabular}{|lllll|}
\hline$\diamond 3 \mathrm{~s}$ & $\square 6 \mathrm{~s}$ & $\Delta 9 \mathrm{~s}$ & $\times 12 \mathrm{~s}$ & $* 15 \mathrm{~s}$ \\
\hline
\end{tabular}

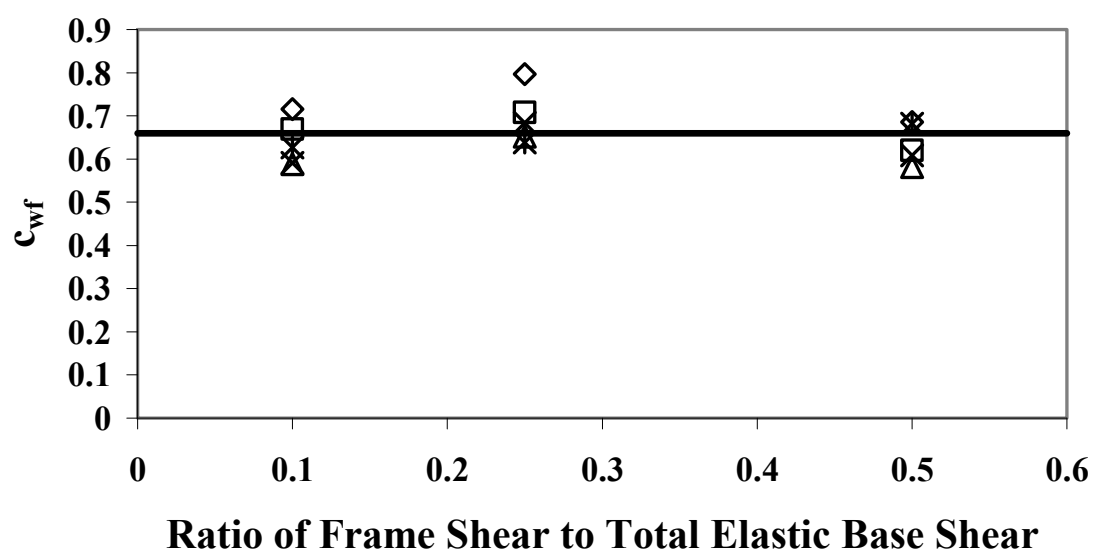

Figure 3.11: The Distribution Factors for the Wall-Frames 


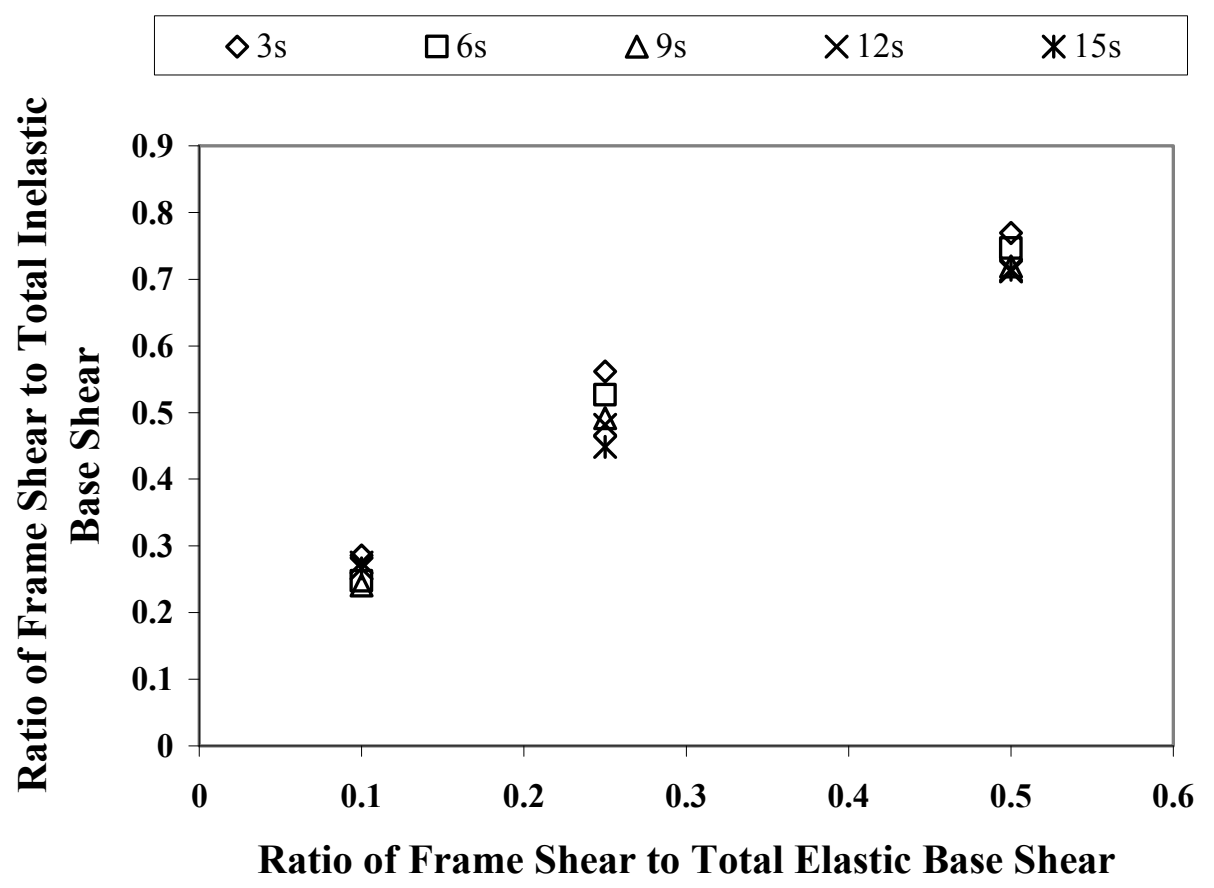

Figure 3.12: Frame Contribution in the Inelastic Response

The overstrength of each system can be found from base shear values or can be quantified from the displacements presented in Tables 3.9, 3.10, 3.11 and 3.12. Basically, the overstrength for a particular system is the ratio between the displacement at the collapse level and the displacement at the first significant yield. Either ISDR or TSDR can be used to obtain the overstrength values. The overstrength possessed by these systems are plotted against the elastic load share ratio $(\xi)$ in Figure 3.13. According to this figure, the overstrength of walls $(\xi=0)$ is on the order of 3.3. This high value of overstrength is due to the stiff boundary members, especially the HBEs, utilized in design. It is also observed that the overstrength values can reach to 7 for systems with $\xi=0.5$. This is natural because of the stiff framing utilized together with the wall. As mentioned before, the frame member sizes were selected based on stiffness requirements to satisfy a certain ratio of base shear. 
Therefore, the members were overdesigned from a strength point of view. The members which were overdesigned to meet the base shear ratio criterion result in significant amount of overstrength. The overstrength of systems studied herein can be quantified by fitting a best line to the data points shown in Figure 3.13 and can be represented as follows:

$$
\Omega_{o}=5.66 \xi+3.38
$$

It should be noted that Equation 6 is particular to the systems studied herein and cannot be generalized. If other framing members with the same stiffness but different strength are selected, than the expected overstrength will change.

\begin{tabular}{|lllll|}
\hline$\diamond 3 \mathrm{~s}$ & $\square 6 \mathrm{~s}$ & $\Delta 9 \mathrm{~s}$ & $* 12 \mathrm{~s}$ & $* 15 \mathrm{~s}$ \\
\hline
\end{tabular}

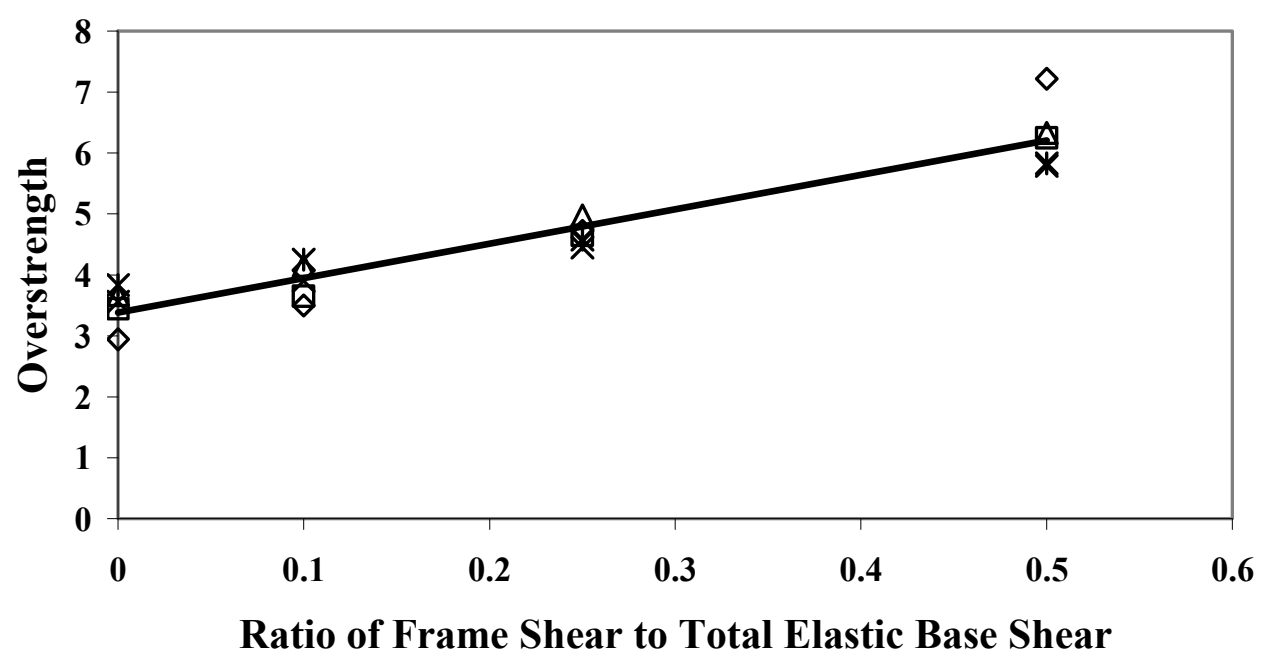

Figure 3.13: Overstrength Possessed by the Systems 


\subsection{Relationship between Elastic and Inelastic Displacements}

Equal displacement rule is generally utilized in the study of response factors. Studies on single degree of freedom systems revealed that the amount of displacement that the structure experiences is the same whether the structure behaves elastic or inelastic. Inelastic displacements can be greater than the elastic displacements for short period structures. By making use of the equal displacement rule, a set of quasistatic analysis is sufficient to study the response factors without conducting a dynamic analysis.

The applicability of the equal displacement rule is investigated in this section. The ratio of the inelastic drift to the elastic drift is plotted against the fundamental natural period of the structure in Figures 3.14 and 3.15. Both the ISDR and the TSDR were considered. According to these figures inelastic displacements can be greater than the elastic displacements for short period structures $(\mathrm{T}<0.5 \mathrm{sec})$. In general, the ratio decreases as the fundamental natural period increases. The average value for all data points is 0.75 for both the ISDR and the TSDR. In general, inelastic drifts are less than the elastic drifts and this observation has to be taken into account in developing the response factors. The same conclusion is also supported by the results shown in Figure 3.6. For the 9 story systems considered in this figure, the elastic displacements are usually higher than the inelastic displacements.

The ratio of interstory displacements were investigated for systems grouped according to their load shares. Similar plots are displayed in Figures 3.16, 3.17, 3.18 and 3.19 for cases with $0 \%, 10 \%, 25 \%$, and $50 \%$ of frame share. In general, the average of the ratios increases as the percentage of frame share increases. This is natural because of the change in the fundamental period. Because systems with higher frame contribution have lower natural periods than the others, the ratios for these systems are greater. 
ALL DATA

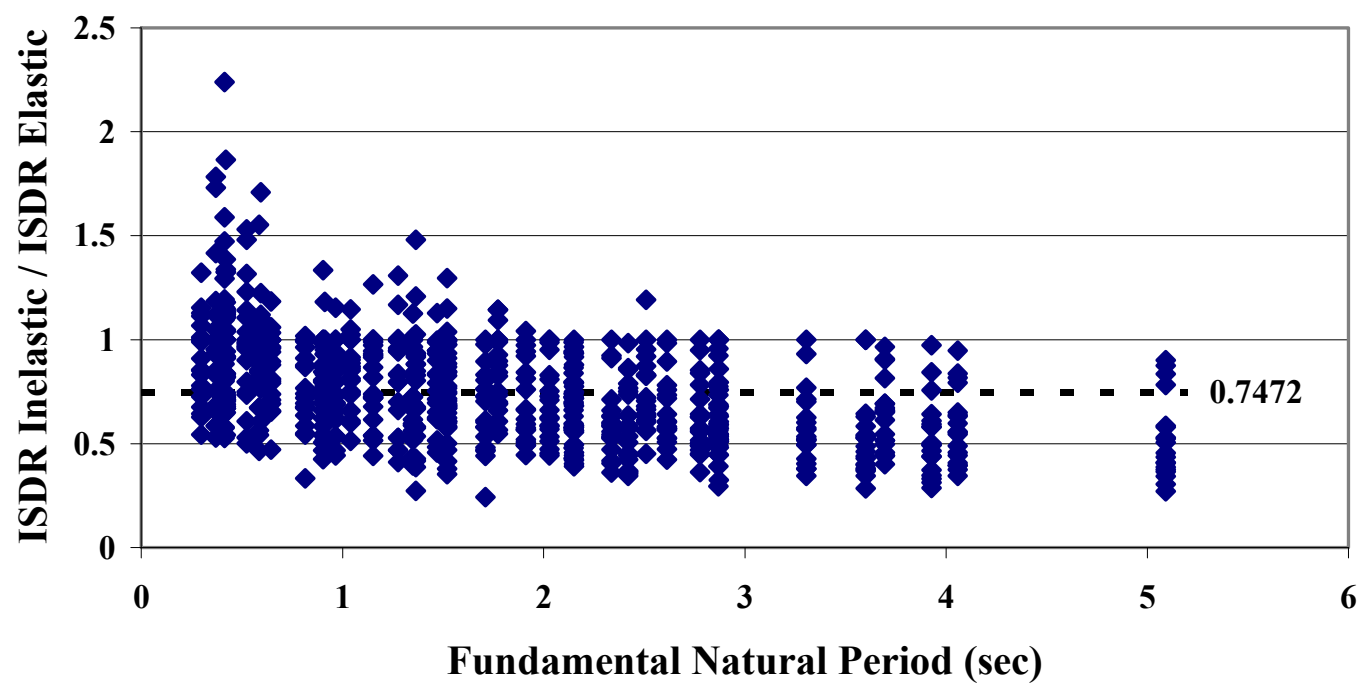

Figure 3.14: ISDR Inelastic / ISDR Elastic for All Data

ALL DATA

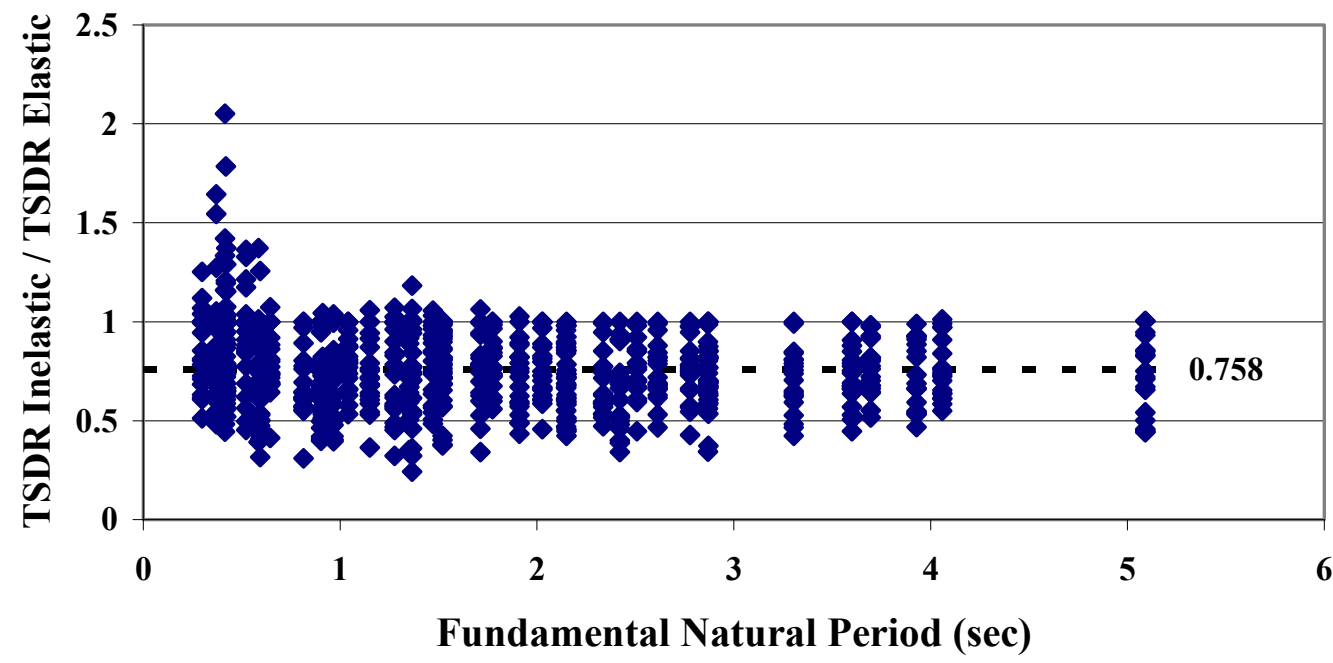

Figure 3.15: TSDR Inelastic / TSDR Elastic for All Data 
0\% Frame Contribution

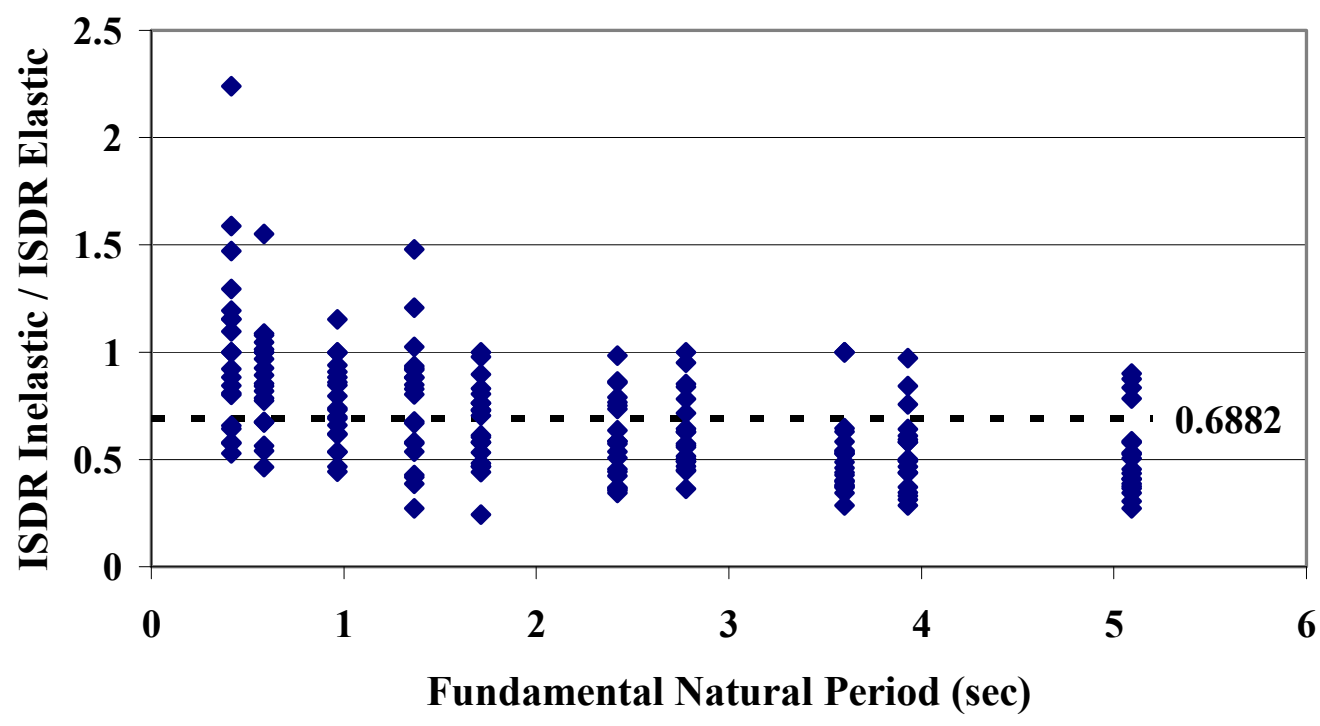

Figure 3.16: ISDR Inelastic / ISDR Elastic for $\% 0$ Frame Contribution

10\% Frame Contribution

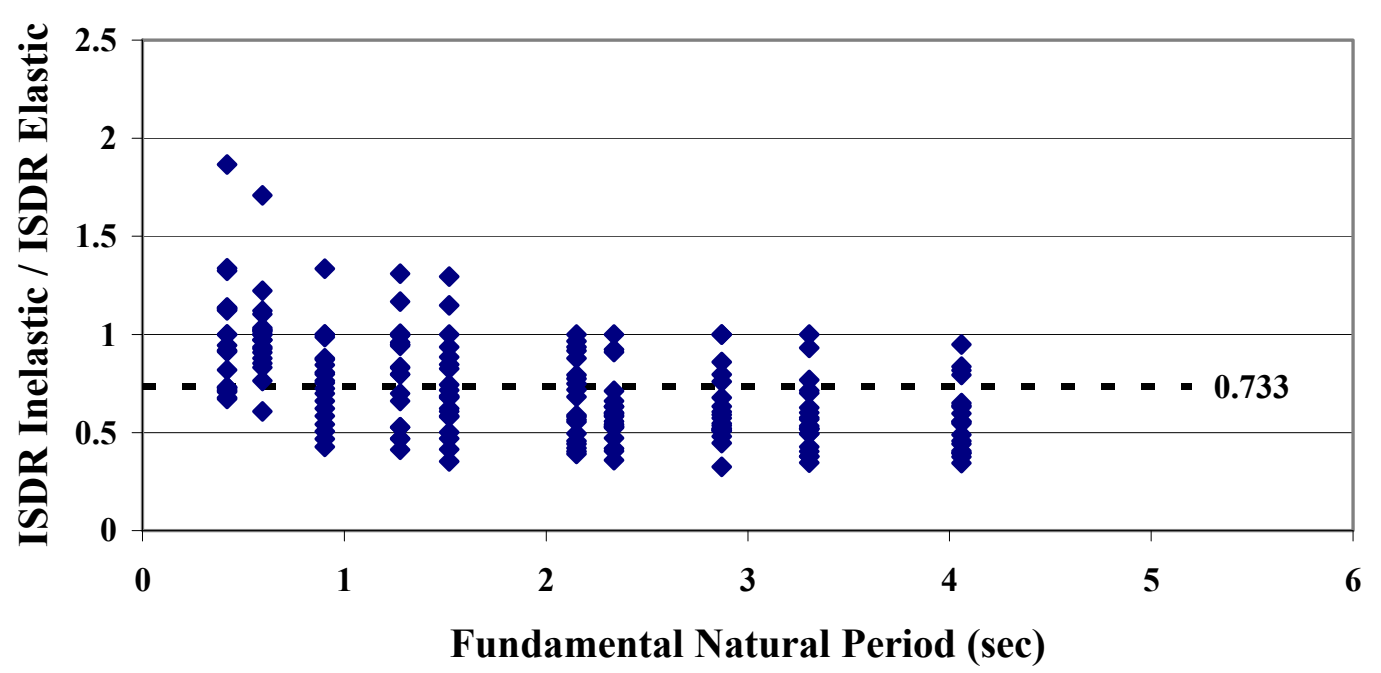

Figure 3.17: ISDR Inelastic / ISDR Elastic for \%10 Frame Contribution 
25\% Frame Contribution

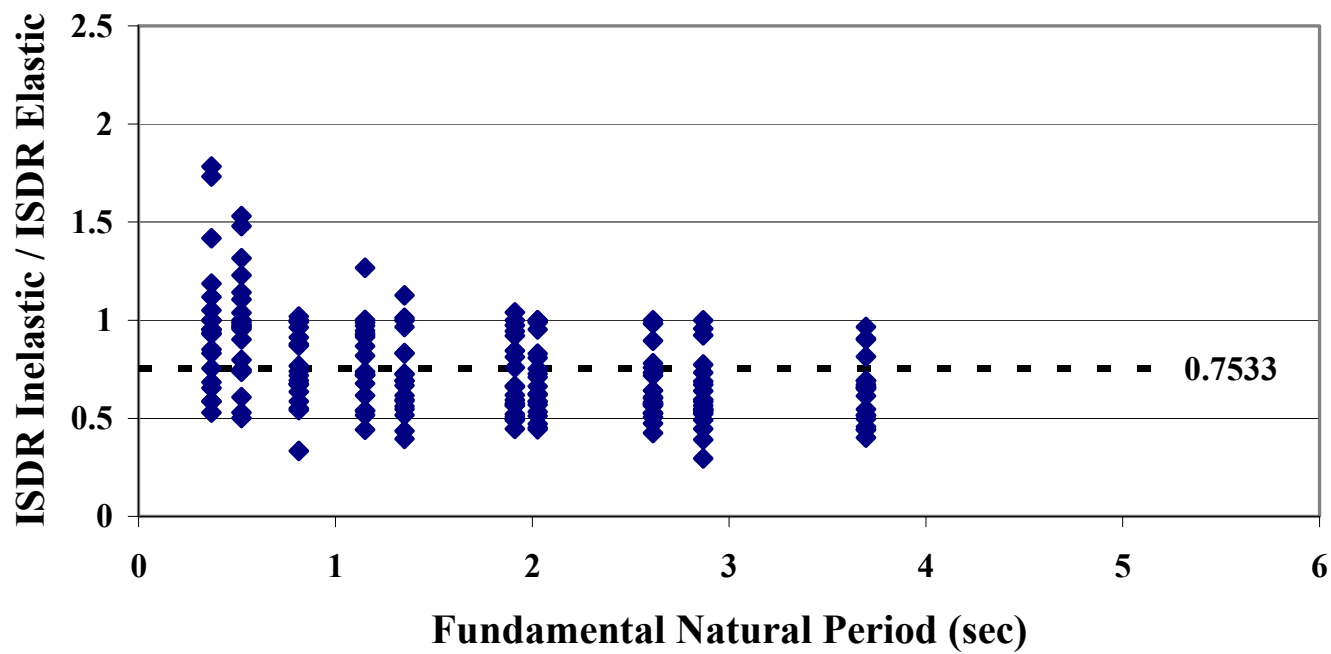

Figure 3.18: ISDR Inelastic / ISDR Elastic for \%25 Frame Contribution

$50 \%$ Frame Contribution

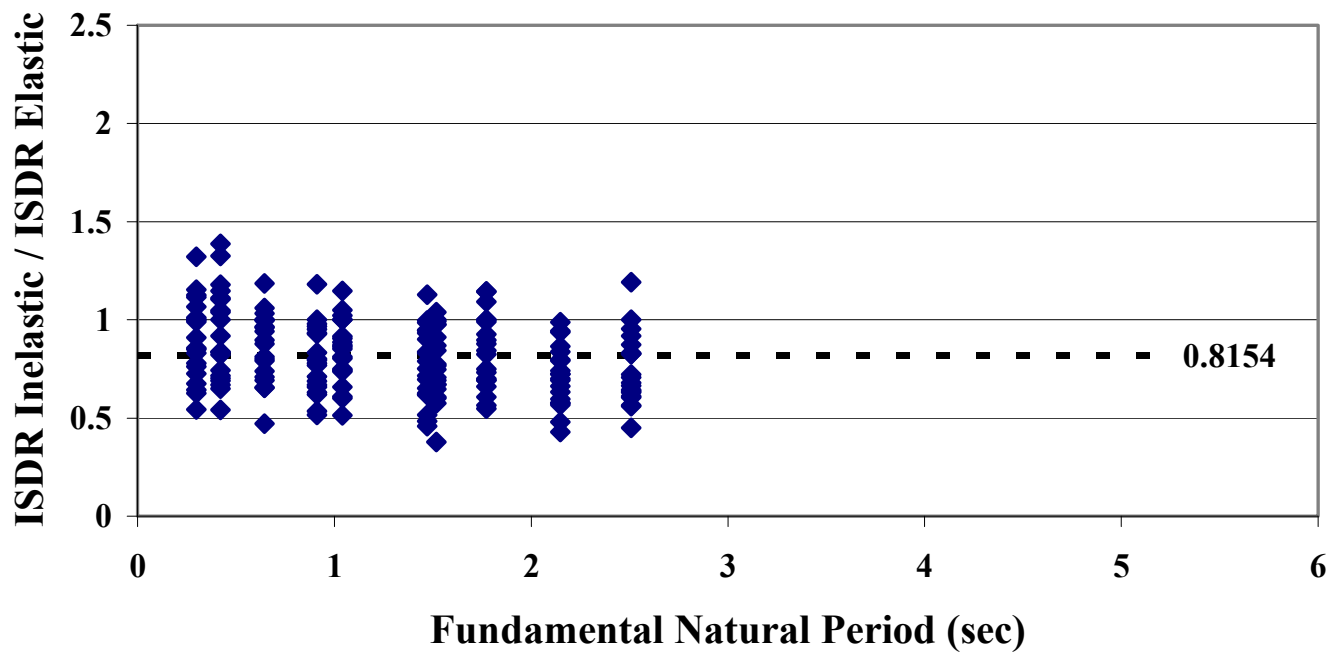

Figure 3.19: ISDR Inelastic / ISDR Elastic for \%50 Frame Contribution 


\subsection{Displacement Amplification Factor, $C_{d}$}

Often times an elastic analysis is conducted in the design of structures. Displacements of the system under earthquake loading are predicted by modifying the displacements from elastic analysis by the $C_{d}$ factor. The value of $C_{d}$ is directly related with the amount of force reduction. Therefore, the discussion on $C_{d}$ should be conducted in conjunction with the response modification factor $(R)$.

Theoretically, $C_{d}$ should be equal to $R$ if equal displacement rule holds. As shown in the previous section, the elastic and inelastic displacements differing from each other result in a violation of $R=C_{d}$. In order to help readers follow the thought process and to show the scatter in results, the elastic displacements were considered first. For each analysis case, the maximum elastic displacement was normalized by the displacement at first yield. Similarly, the elastic base shear was normalized by the base shear at the first significant yield. The plots for normalized ISDR and TSDR are given in Figures 3.20 and 3.21. The trendlines fitted to both curves show exactly $R=C_{d}$ trend. The scatter in results is attributable to the variation in ground motion characteristics. When a structure is subjected to different ground motions, the maximum force versus maximum displacement relationship is not perfectly linear. Depending on the dominant frequency of the ground motion and the structural periods, results can deviate from linearity as shown in Figure 3.6. Observations from Figures 3.20 and 3.21 reveal that the TSDR values are more scattered as compared to the ISDR values. Therefore, from this perspective, using interstory drift is better than using top story drift as an index.

After investigating the results for elastic behavior, the inelastic behavior was investigated next. The $\mathrm{R}$ and $C_{d}$ relationship for inelastic displacements is also given in Figures 3.22 and 3.23. The trendlines fitted to the data points have a slope of 1.37 $\left(R=1.37 C_{d}\right)$ and $1.40\left(R=1.40 C_{d}\right)$ for normalized ISDR and TSDR, respectively. 
As noted earlier, the ratio of the inelastic displacements to the elastic displacements was 0.75 on average. The inverse of this ratio $\left(0.75^{-1}\right)$ is 1.33 which is close to the slopes of the trendlines.

Behavior of systems with different load shares was also investigated. The slope of the trendline for normalized ISDR is equal to $1.47,1.35,1.37$, and 1.29 for systems with $0 \%, 10 \%, 25 \%$, and $50 \%$ frame share, respectively. Similarly, the slope of the trendline for normalized TSDR is equal to $1.38,1.43,1.42$, and 1.38 for systems with $0 \%, 10 \%, 25 \%$, and $50 \%$ frame share, respectively. Based on these results, it can be concluded that the load distribution has negligible effect on the displacement amplification factor. Slight differences in the slopes stem from the fact that the displacement ratios are different between the systems with different load shares as explained in the previous section. For example, the average displacement ratio is 0.68 for $0 \%$ frame contribution and 0.81 for $50 \%$ frame contribution as shown in Figures 3.16 and 3.19, respectively. The fundamental natural periods of the wallonly systems ( $0 \%$ frame contribution) is inherently higher than the wall-frame systems leading to smaller displacement ratios which in turn lead to smaller $C_{d}$ values. 


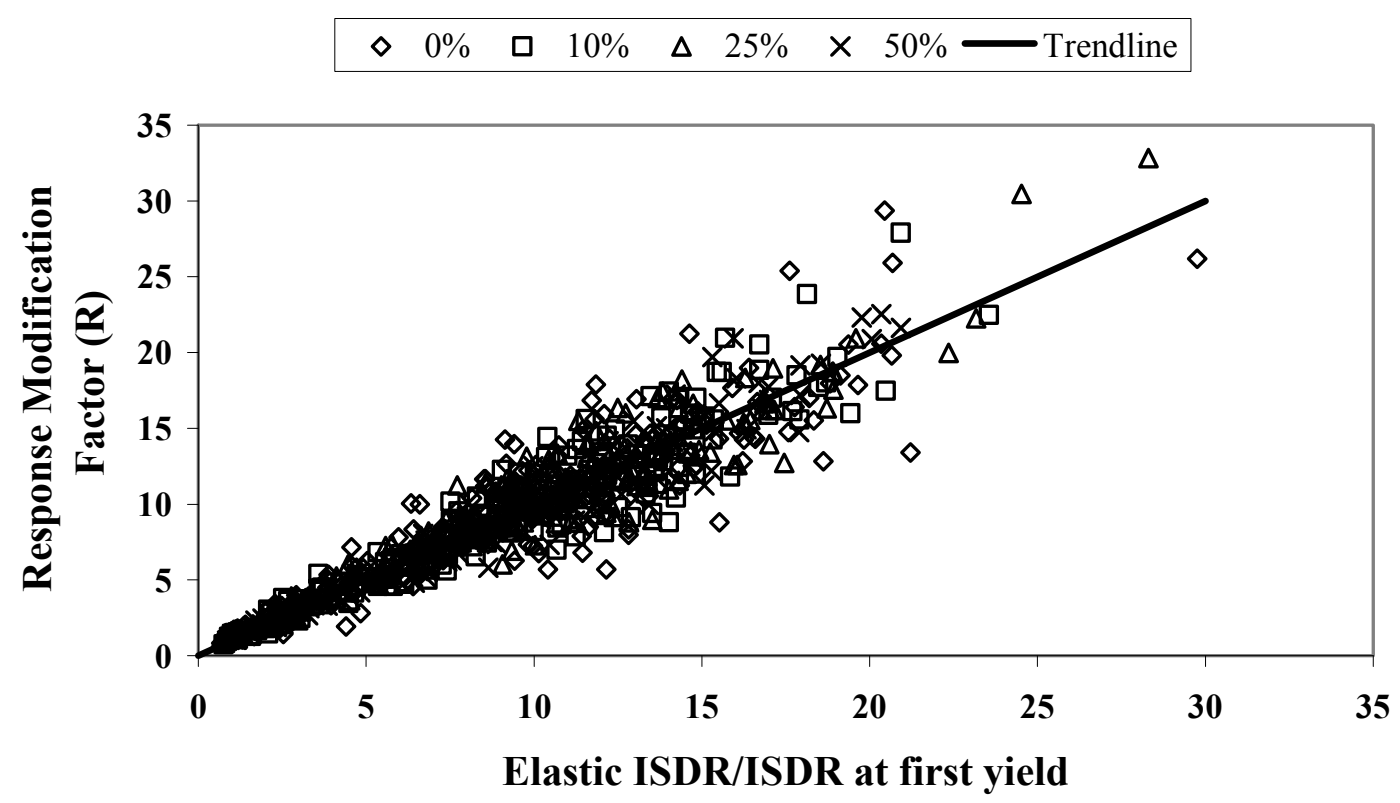

Figure 3.20: R vs. Elastic ISDR / ISDR at First Yield

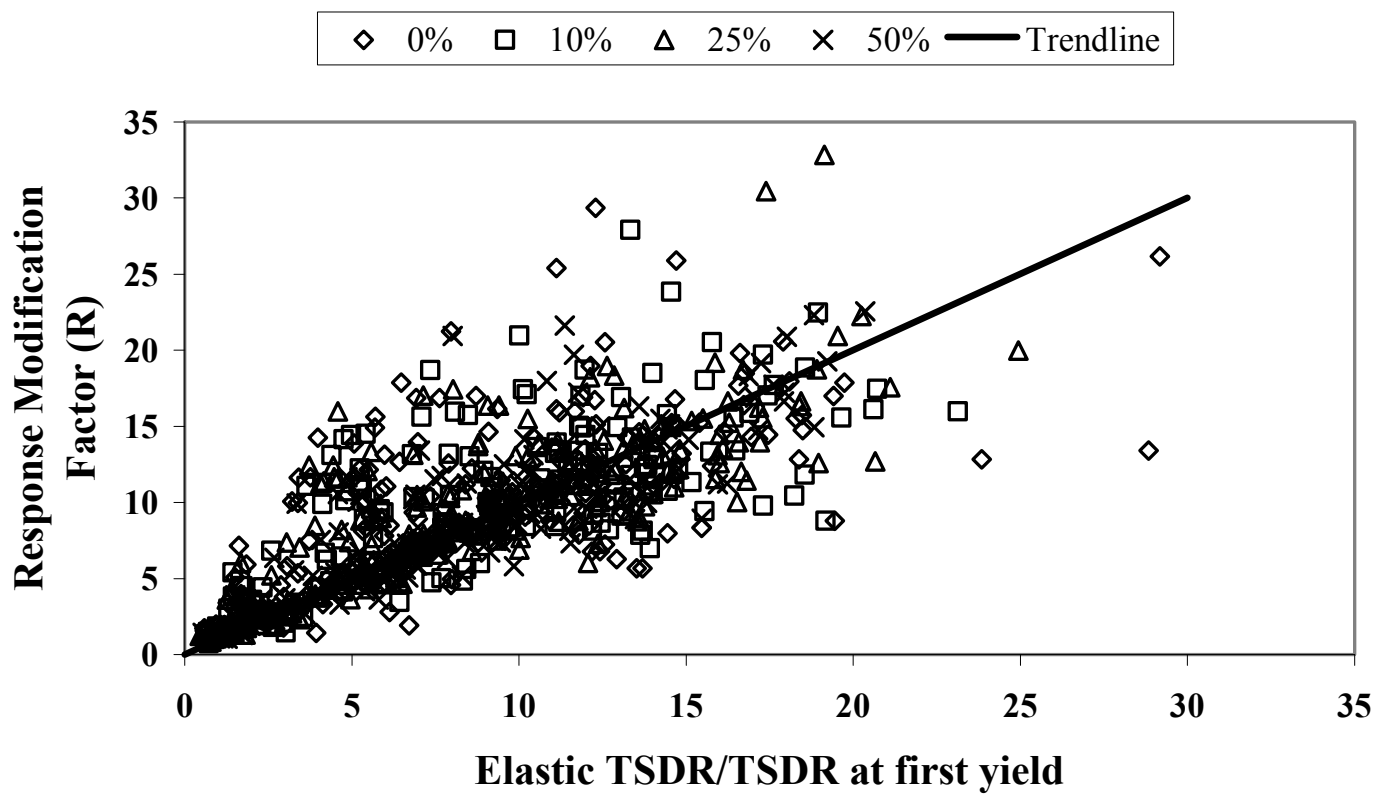

Figure 3.21: R vs. Elastic TSDR / TSDR at First Yield 


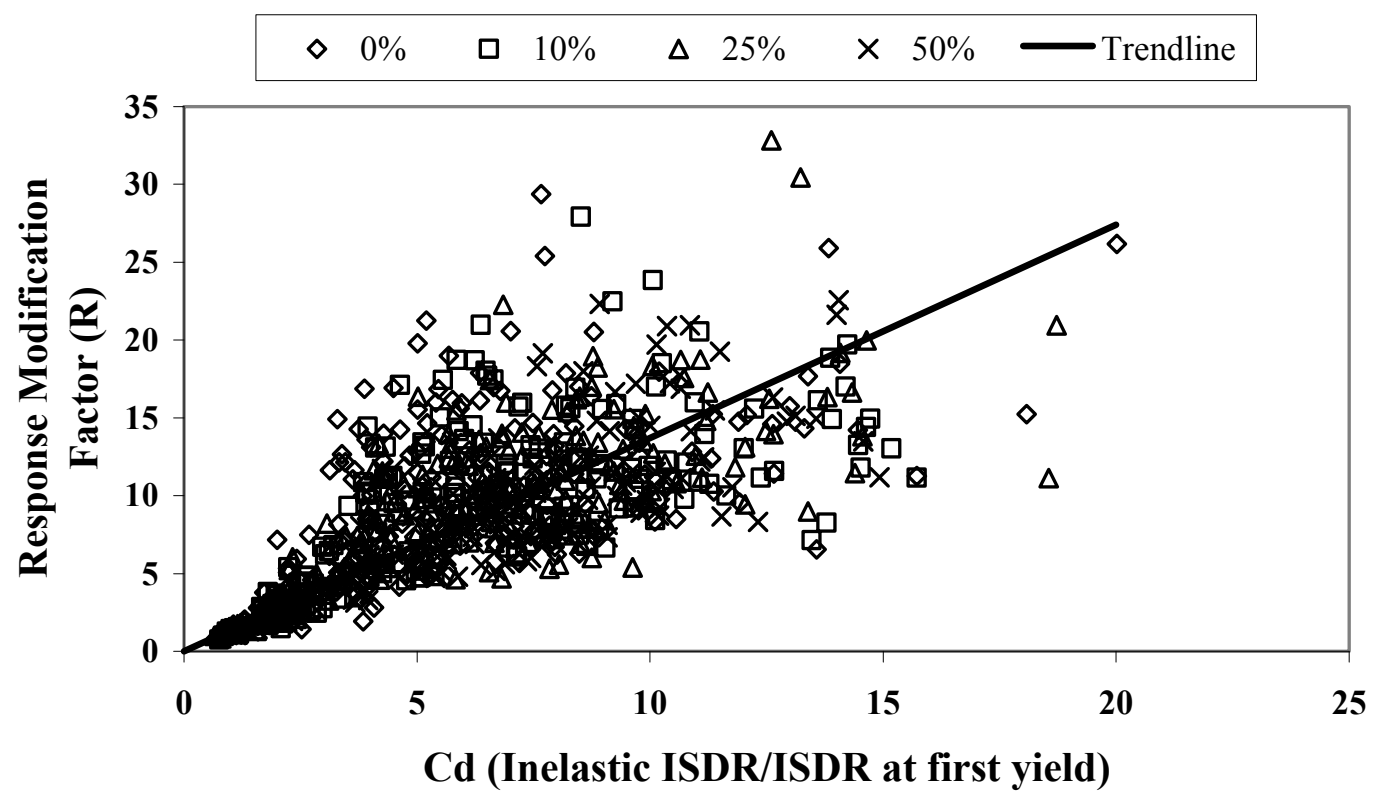

Figure 3.22: R vs. Cd (Inelastic ISDR / ISDR at First Yield)

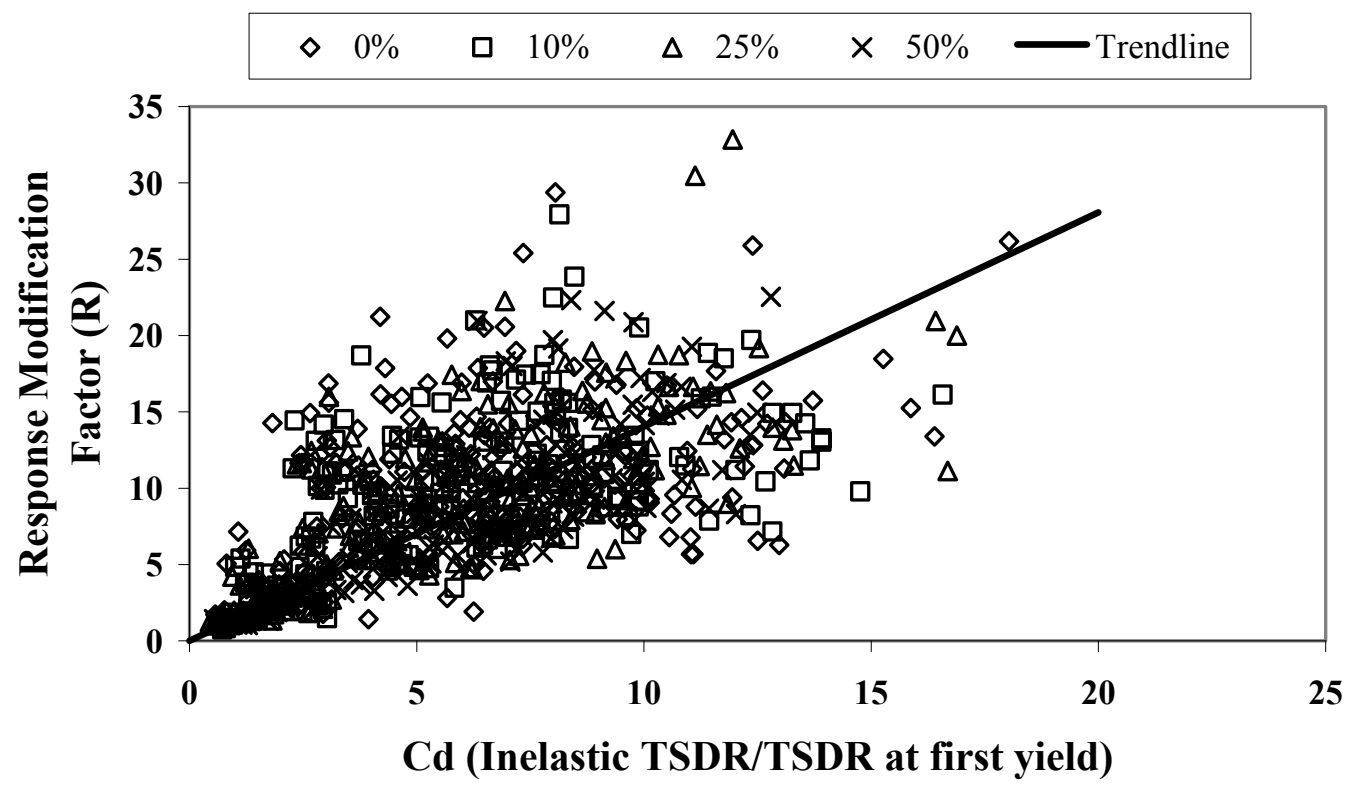

Figure 3.23: R vs. Cd (Inelastic TSDR / TSDR at First Yield) 


\subsection{Response Modification Factor, $\mathbf{R}$}

Response modification factor is a combination of the overstrength factor and the ductility reduction factor. Based on this observation, one can expect that the $R$ values should increase with an increase in the overstrength of the systems. For the systems studied herein, the overstrength values increase with an increase in the ratio of the frame contribution. Therefore, it is expected that the $R$ values increase with increasing $\xi$.

For all elastic analysis cases, the $R$ values were computed by normalizing the base shear with the base shear at the first significant yield. The variation of $R$ values was investigated by considering their relation with displacement measures. The $R$ values are plotted against the elastic ISDR, inelastic ISDR, elastic TSDR, and inelastic TSDR values in Figures 3.24, 3.25, 3.26, and 3.27. In each plot, data points for different load shares were displayed separately. For instance, Figure 3.26 is the combination of Figures 3.28, 3.29, 3.30 and 3.31. Other figures were constructed similar to this approach. In order to make comparisons, trendlines were fitted to the data points as shown in the Figures 3.24, 3.25, 3.26, and 3.27. The slopes of the trendlines were normalized by the slope of the trendline for $\xi=0$ (wall-only) case. The normalized slopes that represent the normalized $R$ values are also plotted in Figure 3.32 for different displacement measures. According to this figure, the $R$ values increase significantly with an increase in the load ratio $(\xi)$ if elastic ISDR is considered. However, the change in $R$ values is insignificant if other measures are used. In fact, the $R$ values should be correlated using the inelastic displacements because these are the ones that represent the structure's performance under earthquake loading. When inelastic ISDR is considered as an index, the increase in $R$ values are $4 \%, 8 \%$, and $8 \%$ for structures with $\xi$ equal to $10 \%, 25 \%$, and $50 \%$, respectively. IBC specification (2003) recommends 7 for wall only systems and 8 for wall-frame systems with $25 \%$ frame contribution corresponding to $14 \%$ increase in 
$\mathrm{R}$, which is around the results obtained in this study. The change in $R$ values did not turn out to be significantly high as expected from the increase in overstrength. There are several reasons for this outcome. As the frame contribution $(\xi)$ increases, not only the overall stiffness of the structure, but also the base shear at the first significant yield increases.

The overall increase in the ratio of the elastic base shear to the base shear at the first significant yield is not proportional to the increase in the overstrength of the system. In addition, the ductility reduction, as explained in the following section, is significantly influenced resulting in a negligible increase in the overall $R$ values.

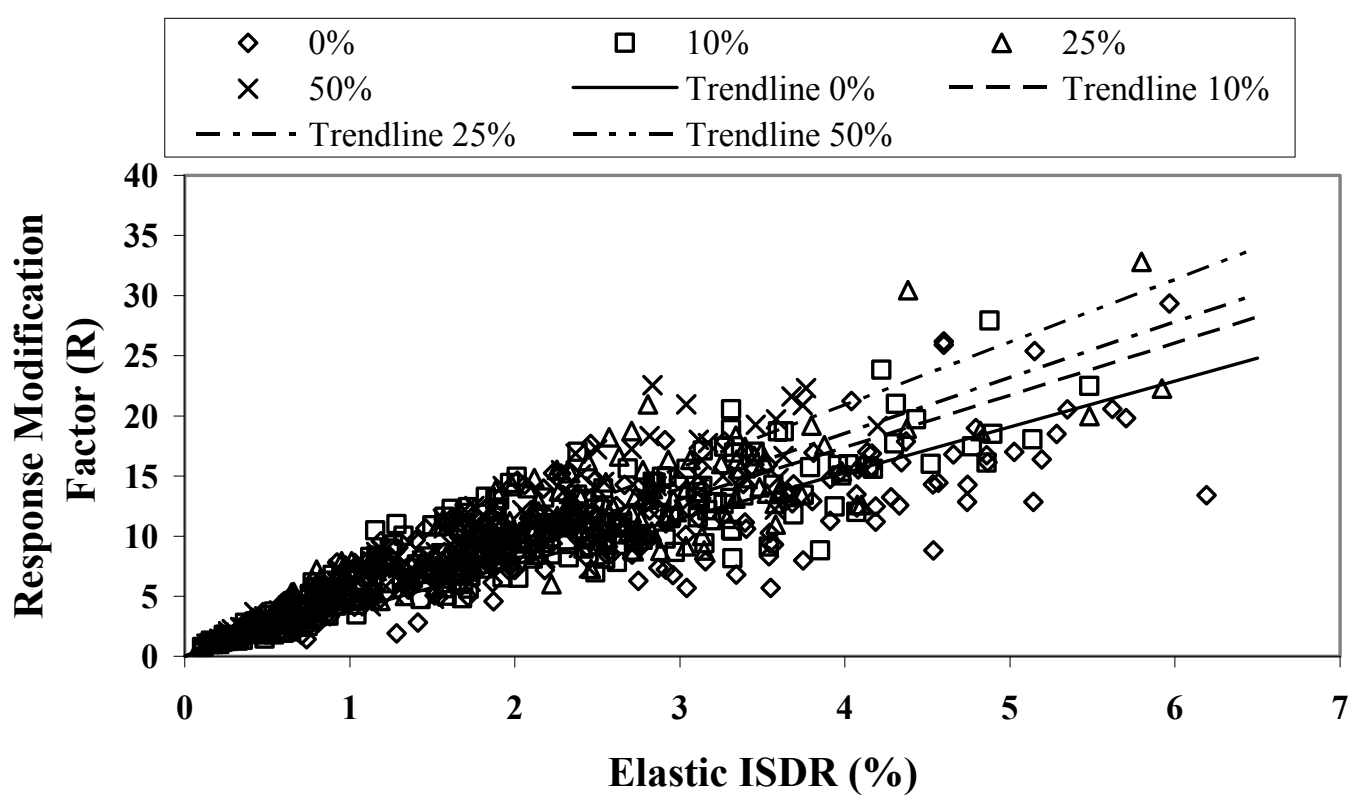

Figure 3.24: R vs. Elastic ISDR 


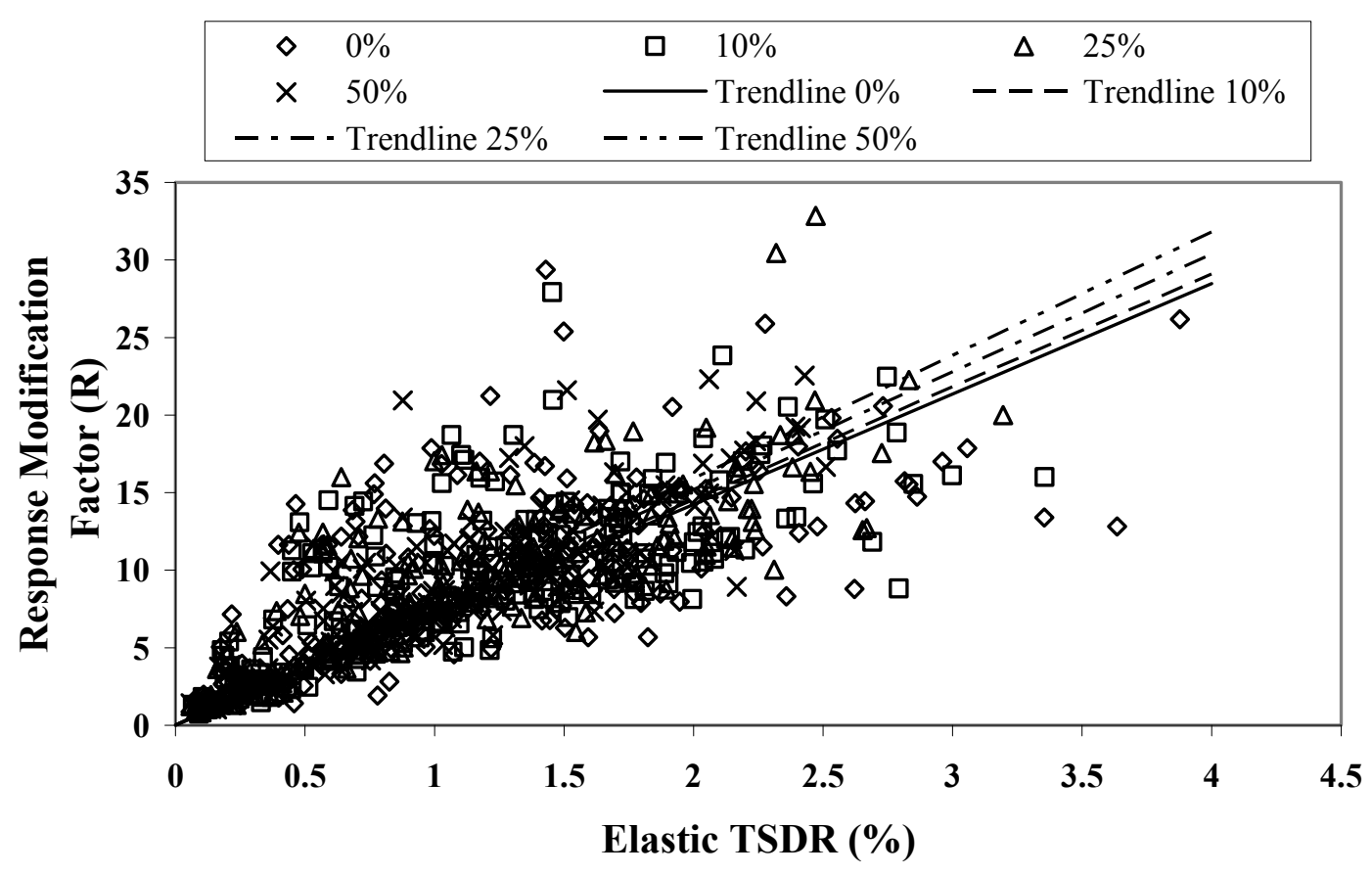

Figure 3.25: R vs. Elastic TSDR

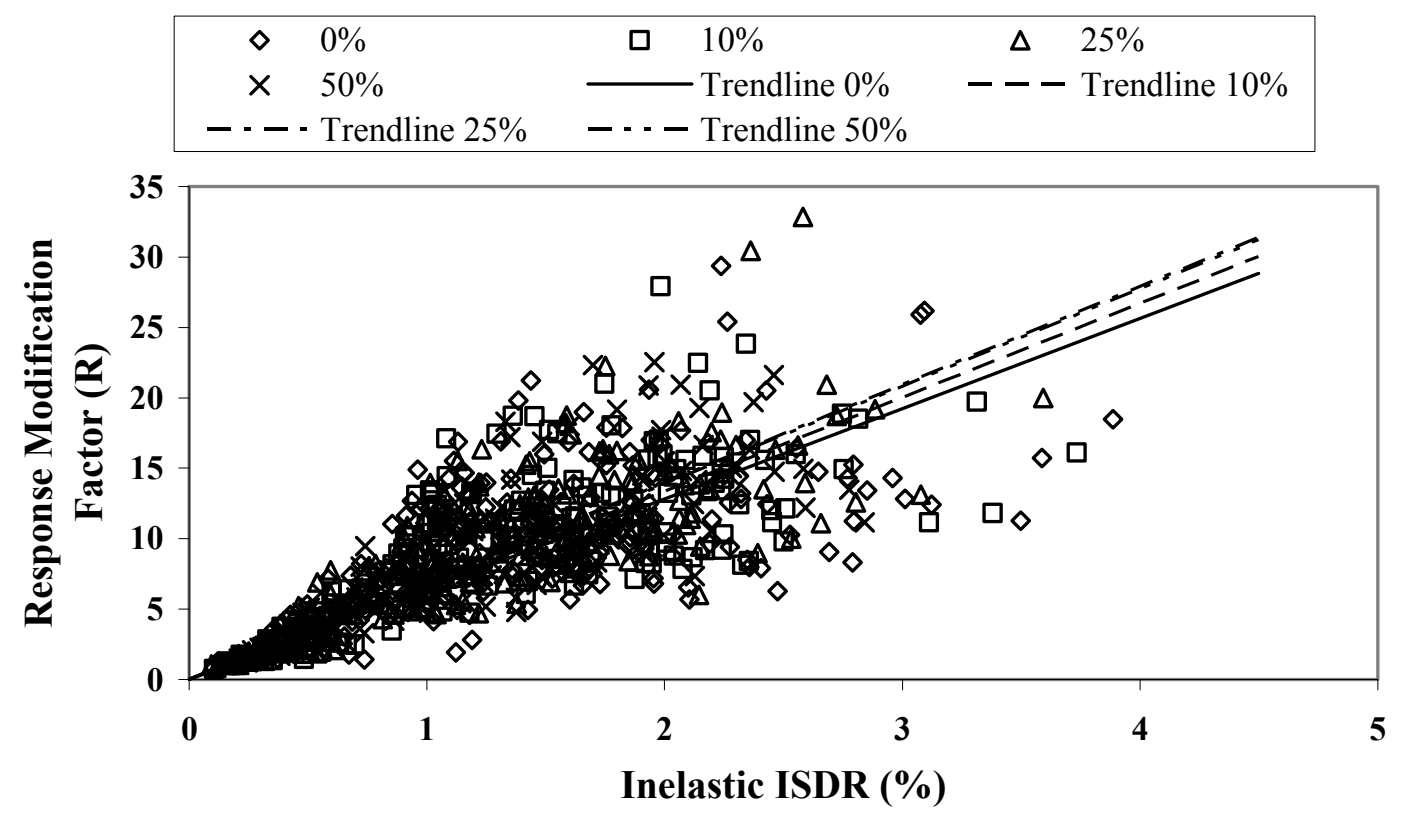

Figure 3.26: R vs. Inelastic ISDR 


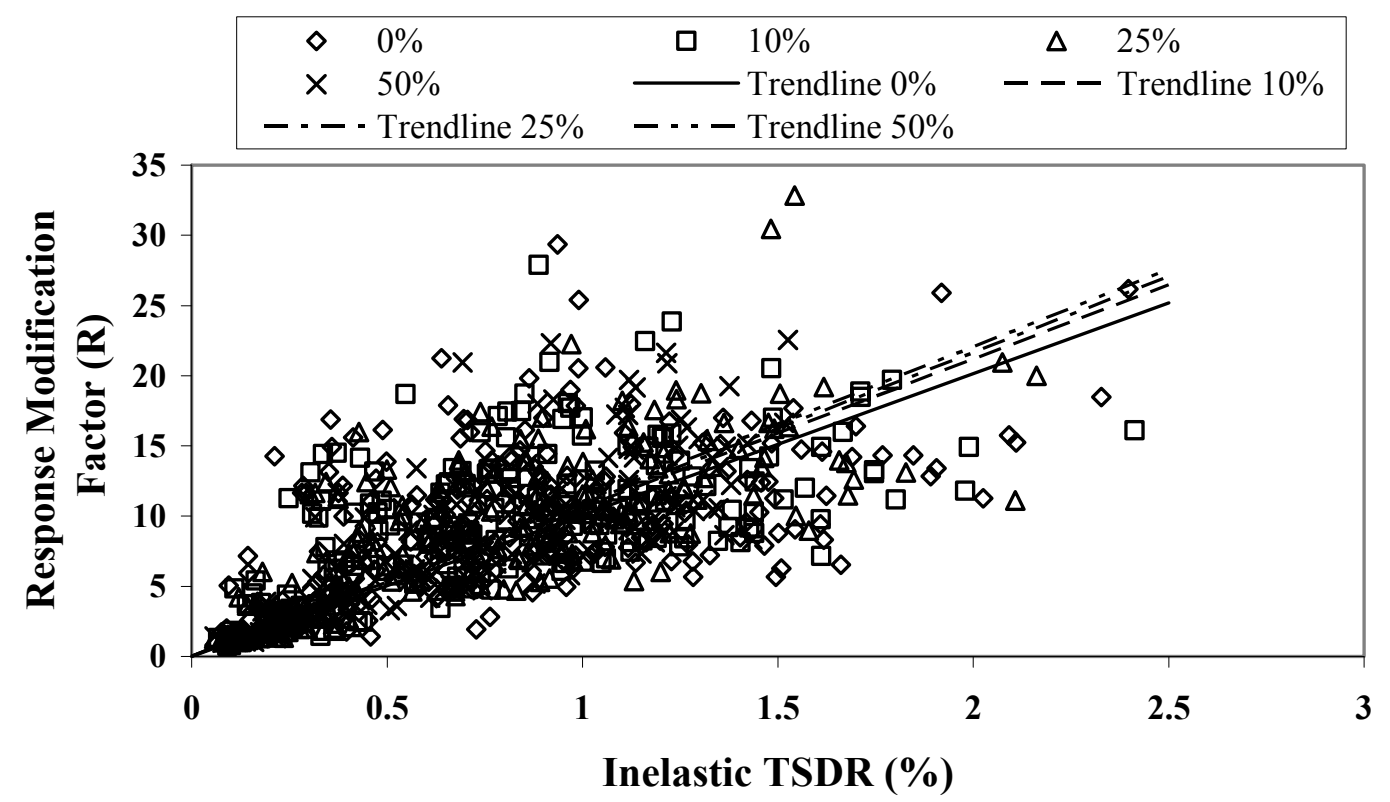

Figure 3.27: R vs. Inelastic TSDR

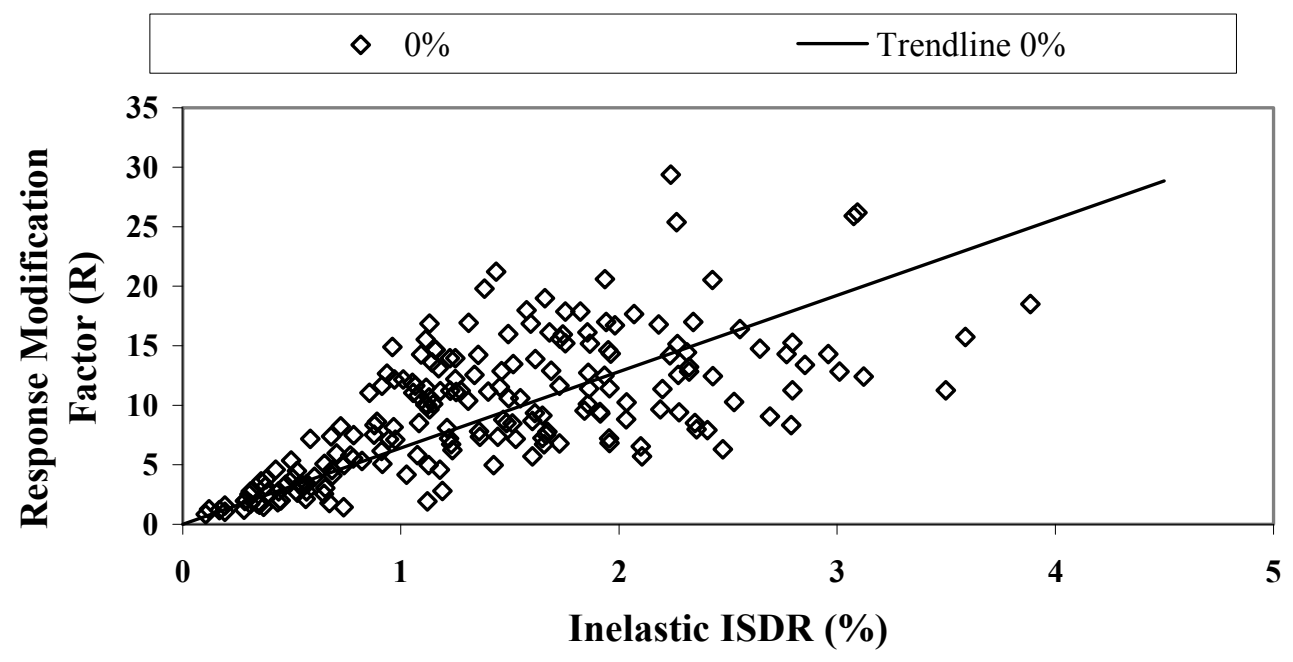

Figure 3.28: R vs. Inelastic ISDR for $0 \%$ Frame Contribution 


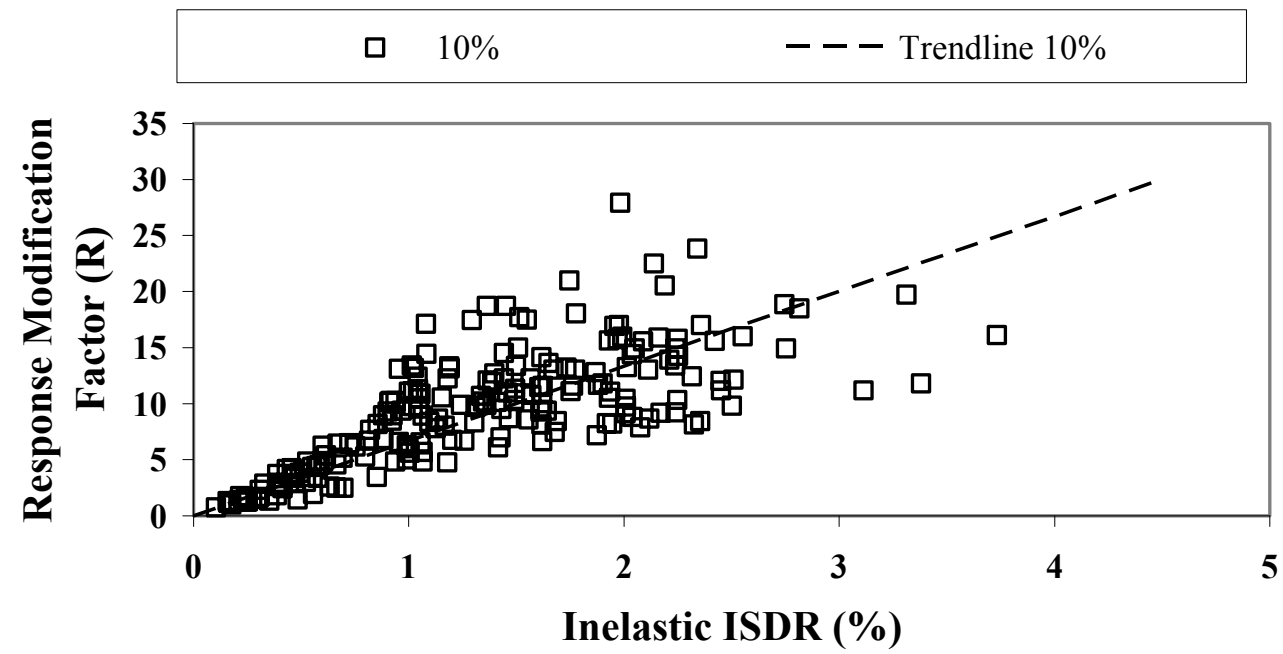

Figure 3.29: R vs. Inelastic ISDR for 10\% Frame Contribution

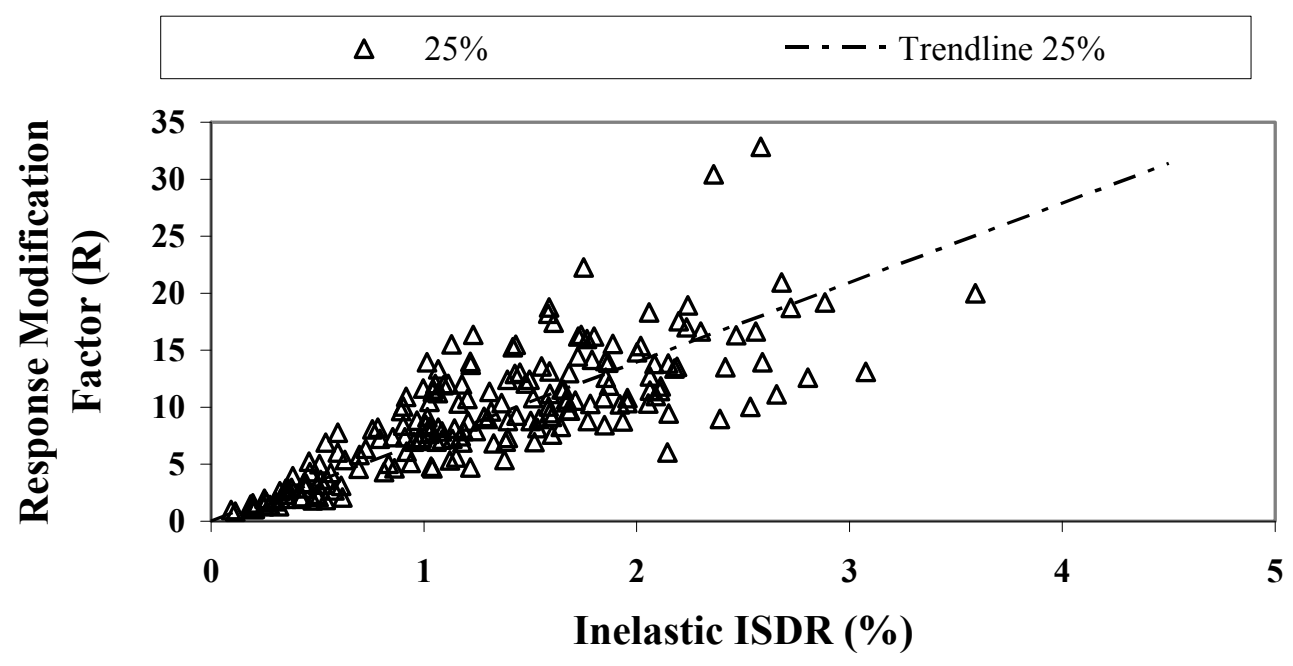

Figure 3.30: R vs. Inelastic ISDR for 25\% Frame Contribution 


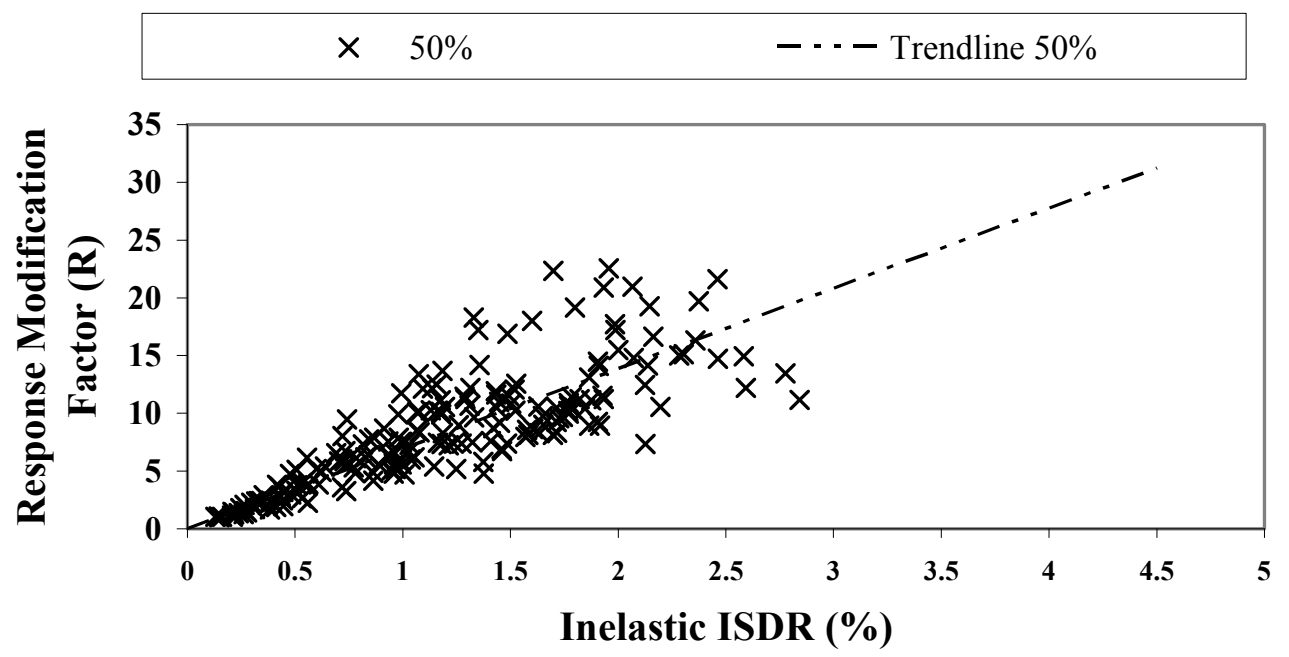

Figure 3.31: R vs. Inelastic ISDR for 50\% Frame Contribution

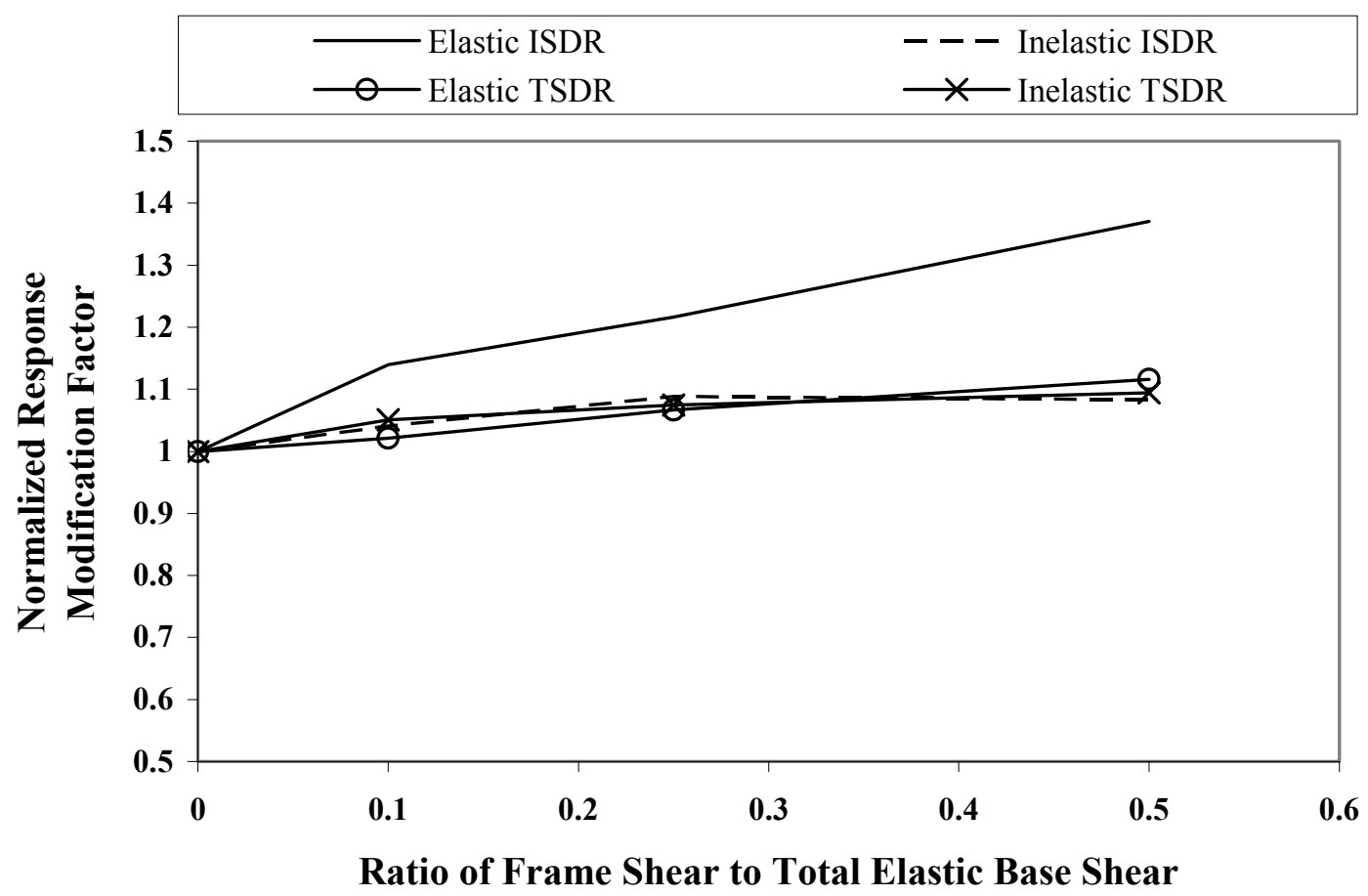

Figure 3.32: Normalized Response Modification Factor vs. Ratio of Frame Shear to Total Elastic Base Shear 


\subsection{Ductility Reduction Factor, $\mathbf{R}_{\mu}$}

Variation of the ductility reduction factor with inelastic ISDR and inelastic TSDR are given in Figures 3.33 and 3.34. Trendlines were fitted to the data points and these are also displayed in this figure. According to these plots, it is evident that the ductility reduction factor decreases with an increase in the frame load share $(\xi)$. Another way to investigate this behavior is to consider the relationship between the response modification factor and the ductility reduction factor. This approach does not require the use of any displacement measure. These two quantities are plotted against each other in Figure 3.35 together with their trendlines. It is obvious that the slope of the trendline increases with an increase in the frame load share $(\xi)$. It should be mentioned that the slope represents the overstrength of the system. Therefore, the slopes of the trendlines increase as the $\xi$ value increases. This figure also reveals the same conclusion that the ductility reduction factor decreases with an increase in the frame load share $(\xi)$. By considering the findings of this section and the previous one, it can be concluded that there is an inverse relationship between ductility and overstrength. In addition, the overall change in the $R$ value with $\xi$ is negligible. 


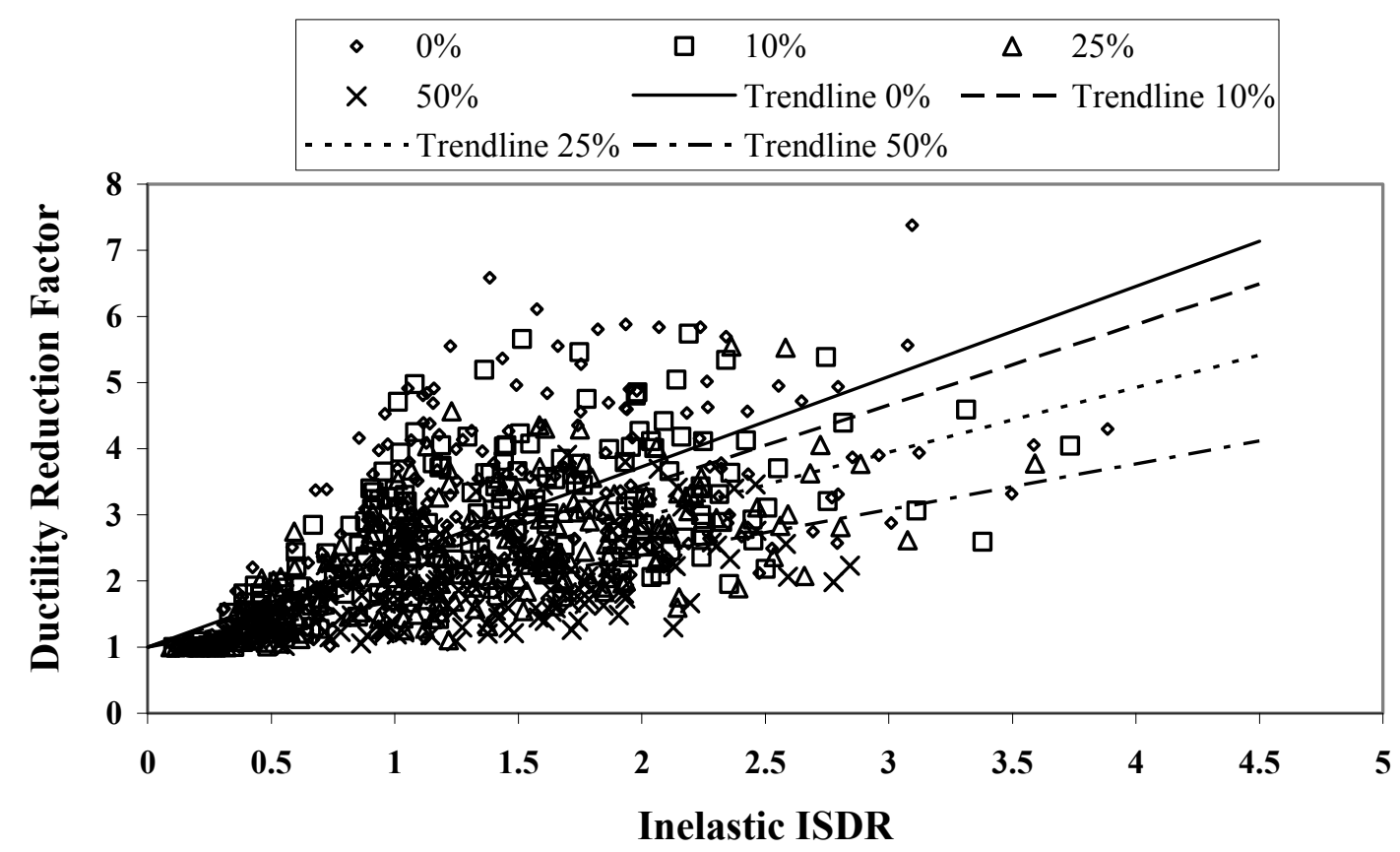

Figure 3.33: Ductility Reduction Factor vs. Inelastic ISDR

\begin{tabular}{|c|c|c|c|c|}
\hline$\diamond$ & $0 \%$ & 口 & $10 \%$ & $\Delta \quad 25 \%$ \\
\hline$x$ & $50 \%$ & 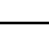 & Trendline $0 \%$ & ---- Trendline $10 \%$ \\
\hline & Trendline $25 \%$ & - - & - Trendline 50\% & \\
\hline
\end{tabular}

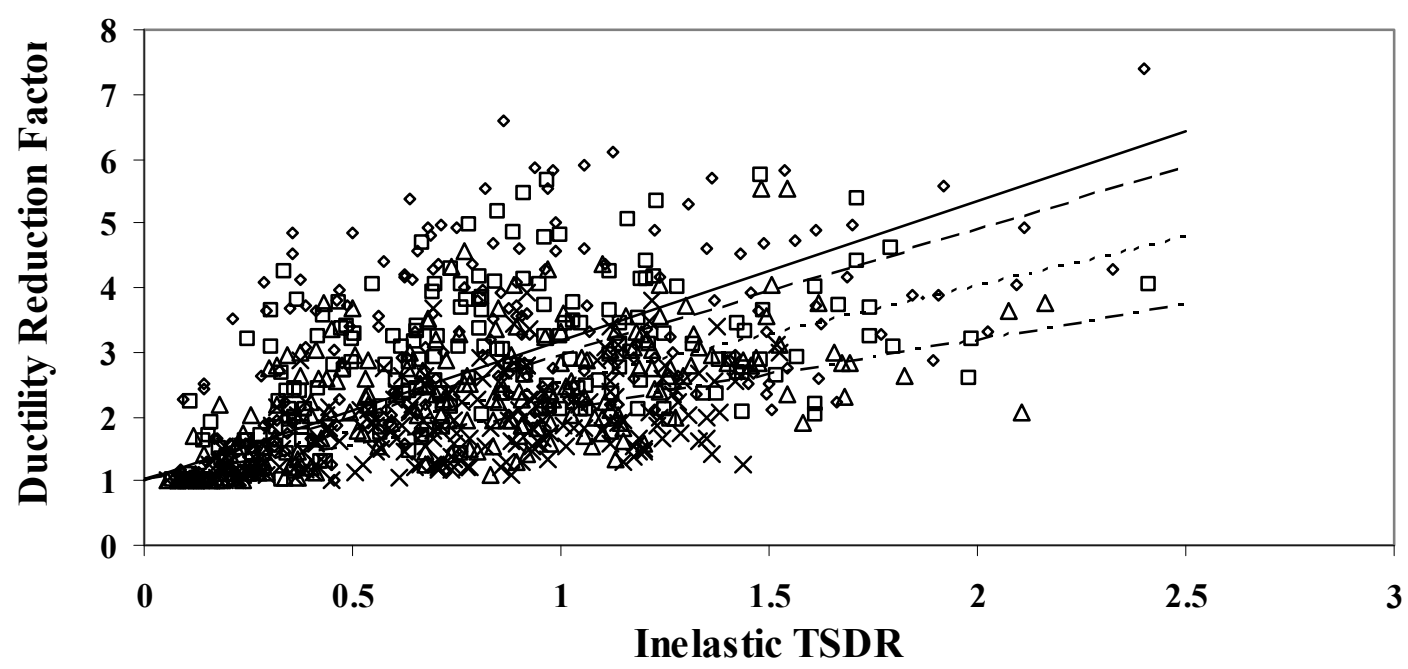

Figure 3.34: Ductility Reduction Factor vs. Inelastic TSDR 


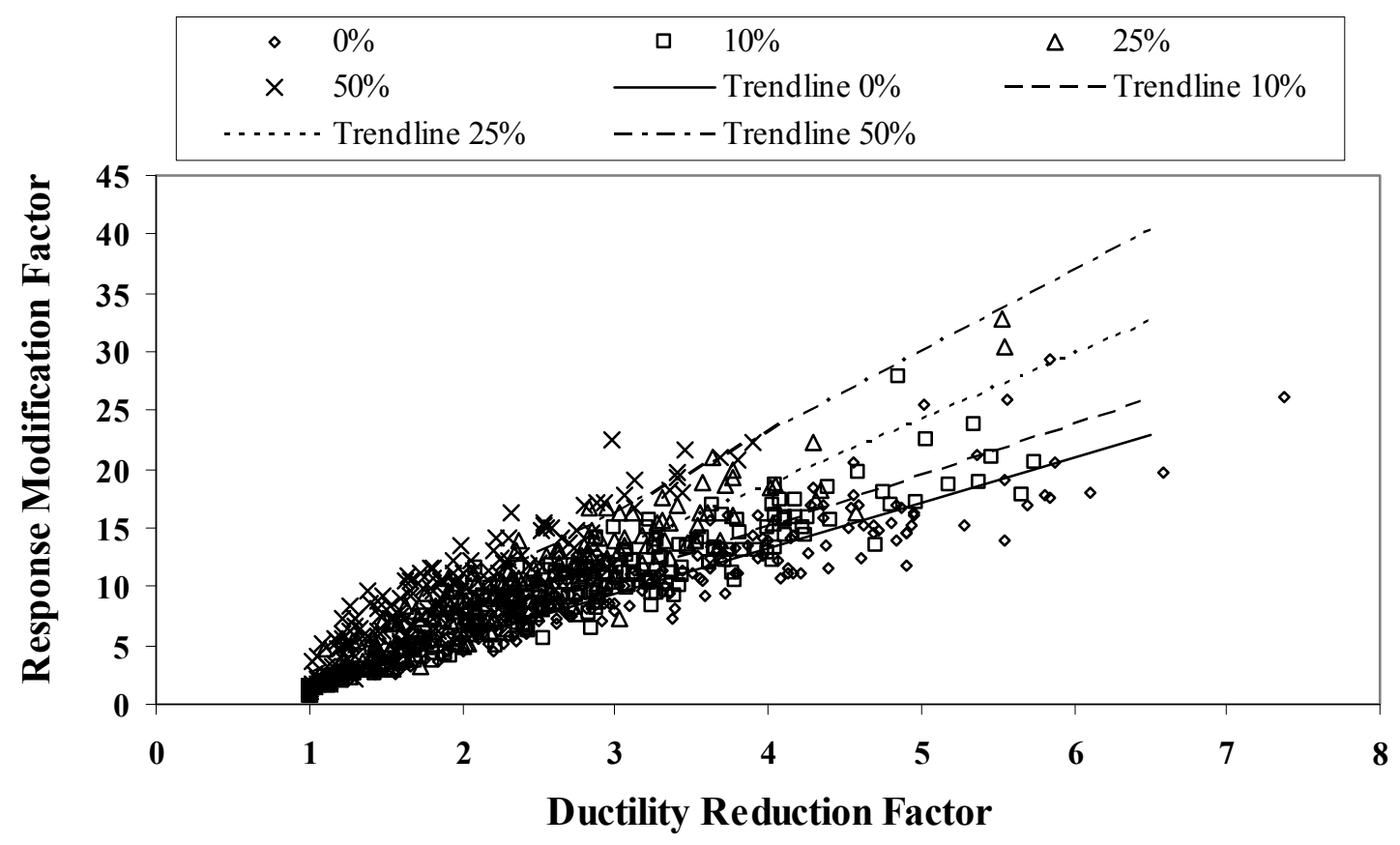

Figure 3.35: Response Modification Factor vs. Ductility Reduction Factor 


\section{CHAPTER 4}

\section{CONCLUSIONS}

A numerical study on 20 hypothetical structures with different mass and stiffness characteristics has been conducted. Wall-frames were selected such that the elastic base shear resisted by the frame has $10 \%, 25 \%$, and $50 \%$ share of the total elastic base shear. All structures were subjected to 20 ground motions and their elastic and inelastic responses were analyzed separately.

The following can be concluded for the structures studied herein:

- Increase in the frame base shear resistance increase the overstrength possessed by the system. In general, stiffness requirements of the frame members govern the member selection rather than strength.

- The results from dynamic analysis were correlated with simple plastic analysis to develop a method for predicting the base shear at the collapse level for steel wall-frames. A set of coefficients were developed which can be directly used in simple plastic analysis.

- A comparison of the elastic and inelastic displacements reveals that the inelastic displacements can be higher than the elastic ones for short period structures. For others, the inelastic displacements are lower than the elastic ones. The average ratio of inelastic to elastic displacements was calculated as 0.75 . 
- The variation of the response modification factor with inelastic displacement measures reveals that there is a negligible increase in $R$ with an increase in the frame load share.

- While the $\mathrm{R}$ value remains constant, there is an inverse relationship between overstrength and ductility reduction. It was found out that the overstrength of the system increases with the amount of frame load share while the ductility reduction factor decreases. 


\section{REFERENCES}

AISC. Seismic Provisions for Structural Steel Buildings, Chicago, IL, 2005.

ANSYS Version 8.1 Online User's Manual, 2006.

ASCE 7-05. Minimum design loads for buildings and other structures. American Society of Civil Engineers, 2005, USA.

Behbahanifard MR. Cyclic behavior of unstiffened steel plate shear walls. Doctoral Dissertation, University of Alberta, 2003.

Berman J, Bruneau M. Plastic analysis and design of steel plate shear walls. Journal of Structural Engineering (ASCE) 2003; 129(11): 1448-1456.

Berman J, Bruneau M. Capacity Design of Vertical Boundary Elements in Steel Plate Shear Walls. Engineering Journal (AISC) 2008; $1^{\text {st }}$ Quarter: 58-71.

Caccese V, Elgaaly M, Chen R. Experimental study of thin steel-plate shear walls under

cyclic load. Journal of Structural Engineering (ASCE) 1993; 119(2):573-587.

Driver RG, Kulak GL, Elwi AE, Kennedy DJL. FE and simplified models of steel plate shear wall. Journal of Structural Engineering (ASCE) 1998; 124(2):121-130.

Driver RG, Kulak GL, Kennedy DJL, Elwi AE. Cyclic test of four-story steel plate shear wall. Journal of Structural Engineering (ASCE) 1998; 124(2):112-120.

Elgaaly M, Caccese V, Du C. Post-buckling behavior of steel-plate shear walls under cyclic loads. Journal of Structural Engineering (ASCE) 1993; 119(2):588-605.

Eurocode 8. Design provisions for earthquake resistance of structures. Part 1. Brussels: CEN (European Committee for Standardization); 1994. 
Heidebrecht AC, Smith BS. Approximate analysis of tall wall-frame structures. Journal of the Structural Division, Proceedings of the American Society of Civil Engineers, 1973; 99(2): 199-221.

International Building Code, International Code Council, 2003.

Kurban OC., Topkaya C. A numerical study on response modification, overstrength, and displacement amplification factors for steel plate shear wall systems. Earthquake Engineering and Structural Dynamics 2009; 38:497-516

Lubell AS, Prion HGL, Ventura CE, Rezai M. Unstiffened steel plate shear wall performance under cyclic loading. Journal of Structural Engineering (ASCE) 2000; 126(4):453-460

Miranda E, Bertero VV. Evaluation of strength reduction factors for earthquake resistant design. Earthquake Spectra 1994; 10(2):357-379.

Park HG, Kwack JH, Jeon SW, Kim WK, Choi IR. Framed steel plate wall behavior under cyclic loading. Journal of Structural Engineering (ASCE) 2007; 133(3):378388.

Rezai M. Seismic behavior of steel plate shear walls by shake table testing. Doctoral Dissertation, The University of British Colombia, 1999.

Roberts TM. Seismic resistances of steel plate shear walls. Engineering Structures 1995; 17(5):344-351

Roberts TM, Sabouri-Ghomi S. Hysteretic characteristics of unstiffened perforated steel plate shear panels. Thin-Walled Structures 1992; 14(2):139-151.

Sabelli RS, Bruneau M. Steel plate shear walls. AISC Steel Design Guide, No:20, 2007, Chicago, Illinois.

Sabouri-Ghomi S, Roberts TM. Nonlinear dynamic analysis of thin steel plate shear walls. Computers and Structures 1991; 39(1/2):121-127. 
Sabouri-Ghomi S, Roberts TM. Nonlinear dynamic analysis of steel plate shear walls including shear and bending deformations. Engineering Structures 1992; 14(5):309317

Sabouri-Ghomi S, Ventura CE, Kharrazi MHK. Shear analysis and design of ductile steel plate walls. Journal of Structural Engineering (ASCE) 2005; 131(6):878-889

Shen C, Tanaka Y, Mizuno E, Usami T. A two-surface model for steels with yield plateau. Japan Society of Civil Engineers, Structural Engineering and Earthquake Engineering 1992; 8(4):179-188.

Smith BS, Crowe E. Estimating periods of vibration of tall buildings. ASCE Journal of Structural Engineering, 1986; 112(5): 1005-1019.

Uang CMU. Establishing $\mathrm{R}(\mathrm{Rw})$ and $\mathrm{Cd}$ factors for building seismic provisions. Journal of Structural Engineering (ASCE) 1991; 117(1):19-28. 